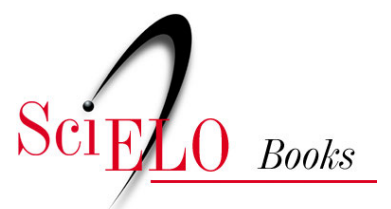

\title{
Saúde, trabalho e formação profissional
}

\author{
Antenor Amâncio Filho \\ M. Cecilia G. B. Moreira
}

AMÂNCIO FILHO, A., and MOREIRA, MCGB., orgs. Saúde, trabalho e formação profissional [online]. Rio de Janeiro: FIOCRUZ, 1997. 138 p. ISBN 85-85471-04-2. Available from SciELO Books <http://books.scielo.org>.

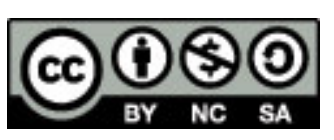

All the contents of this work, except where otherwise noted, is licensed under a Creative Commons Attribution-Non Commercial-ShareAlike 3.0 Unported.

Todo o conteúdo deste trabalho, exceto quando houver ressalva, é publicado sob a licença Creative Commons Atribuição Uso Não Comercial - Partilha nos Mesmos Termos 3.0 Não adaptada.

Todo el contenido de esta obra, excepto donde se indique lo contrario, está bajo licencia de la licencia Creative Commons Reconocimento-NoComercial-CompartirIgual 3.0 Unported. 


\section{SAÚDE,}

\section{TRABALHO E}

FORMAÇÃO PROFISSIONAL

Antenor Amânषio Filho

M. Cecilia G. B. Moreira

Organizadores 


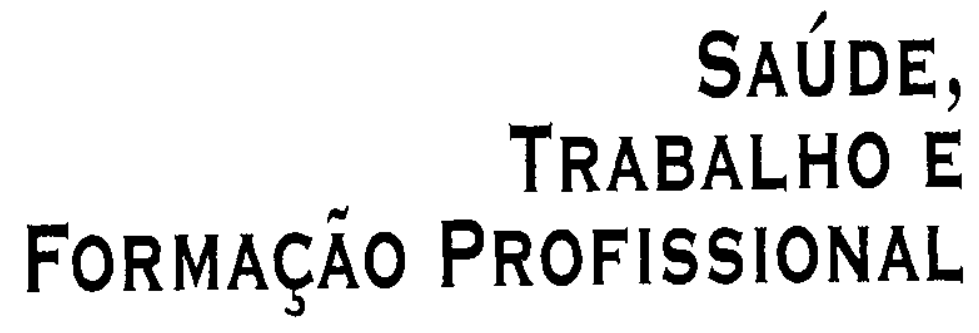




\section{FUNDAÇÃO OSWALDO CRUZ}

\section{Presidente}

Eloi de Souza Carcia

Vice-Presidente de Ambiente, Comunicação e Informaçăo

Maria Cecília de Souza Minayo

\section{EDITORA FIOCRUZ}

\section{Coordenadora}

Maria Cecillia de Souza Minayo

\section{Conselho Editorial}

Carlos E. A. Coimbra Jr.

Carolina M. Bori

Charles Pessanha

Hooman Momen

Jaime L. Benchimol

José da Rocha Canalheiro

Luiz Fernando Ferreira

Miriam Struchiner

Paulo Amarante

Paulo Gadelha

Paulo Marchiori Buss

Vanize Macêdo

Zigman Brener

Coordenador Executivo

Joāo Carlos Canossa P. Mendes 


\section{SAÚDE, \\ TRABALHO E \\ FORMAÇÃO PROFISSIONAL}

Antenor Amâncio Filho

M. Cecilia G. B. Moreira

Organizadores

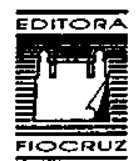


Copyright @ 1997 dos autores

Todos os direitos desta edição reservados à

FUNDAÇÃO OSWALDO CRUZ/EDITORA

ISBN:85-85471-04-2

Capa, Projeto Gráfico e Editoração Eletrônica

Angélica Mello

Imagem da Capa

llustraçāo baseada no desenho "Proporçōes da figura humana", de Leonardo da Vinci

(Galleria Dell'Accademia, Veneza)

Revisão

Fani Knoploch

Digitação

Cenira Fernandes

Supervisão Editorial

Walter Duarte

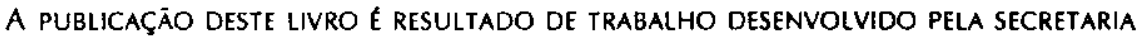
EDITORIAL E DE DIVULGAÇÃo DA ESCOLA POLITÉCNICA de SAÚde JOAQUIM VENÃNCIO, DA FUNDAÇĀO OSWALDO CRUZ.

Catalogação-na-fonte

Centrr te Informação Científica e Tecnológica

Biblioteca Lincoln de Freitas Filho

A484s

Amâncio Filho, Antenor (Org.)

Saúde, trabalho e formação profissional//Organizado por Antenor Amâncio

Filho e M. Cecilia G. B. Moreira - Rio de Janeiro: FIOCRUZ, 1997. $138 \mathrm{p}$.

1. Ocupações em saúde. 2. Educação profissional. 3 Pessoal técnico de saúdeeducaçāo. I. Moreira, M. Cecilia G. B. (Org.).

CDD.- 20. ed. -610.73

1997

EDITORA FIOCRUZ

Rua Leopoldo Bulhōes, 1480, Térreo - Manguinhos

21041-210 - Rio de Janeiro - RJ

Tel.: 590-3789 ramal 2009

Fax.: (021) 280-8194 


\title{
AUTORES
}

\author{
Alina Maria de Almeida Souza \\ Professora de Departamento de Saúde Coletiva e Núcleo de Estudos de Saúde Pública da \\ Universidade de Braślia
}

\section{Hésio de Albuquerque Cordeiro}

Professor do Institulo de Medicina Sorial da Uerj

\section{Joaquim Alberto Cardoso de Melo}

Professor do Departamento de Ciências Sociais da Ensp/Fiocruz e da Escola Polítécnica de Saúde Joaquim Venâncio/Fiocruz

\section{Maria Cecília de Souza Minayo}

Profcssora Adjunta do Departamentu de Ciências Suciais da Ensp/Fiocruz

\section{Maria Umbelina Caiafa Salgado}

Professora do Programa de Pós-Graduação en Educaçāo da Universidade Federal do Espírito Santo

\section{Marília Bernardes Marques}

Professora e Pesquisadora da Fiocruz

\section{Roberto Passos Nogueira}

Assessor do Ministério da Saúde

\section{Rogério Valle}

Professor do Programa de Engenharia de Pridução da Coppo/UFRI 



\section{A Joaquim Alberto Cardoso de Melo}





\section{SUMÁRIO}

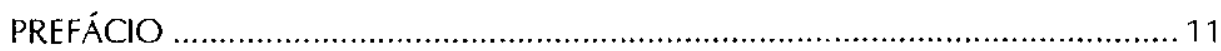

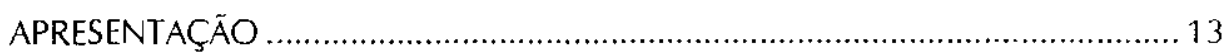

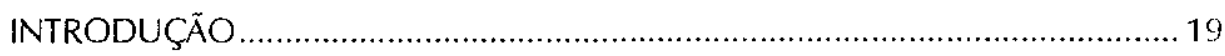

I. SAÚDE: CONCEPÇÕES E POLÍTICAS PÚBLICAS

1. Saúde e doença Como expressão Cultural

Maria Cecilia de Souza Minayo

2. O Conceito de Necessidades de Saúde e as Políticas Sanitárias

Hésio de Albuquerque Cordeiro

3. Debate

I1. RELAÇŌES DE TRABALHO NO SETOR SAÚDE

4. Educação e Saúde: Dimensónes da Vida e da Existência humana

Joaquim Alberto Cardoso de Melo

5. As Dimensões do Trabalho em Saúde

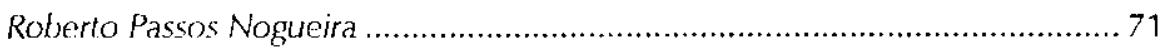

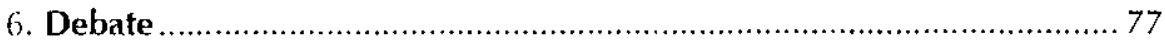

11I. FORMAÇÃO PROFISSIONAL: DIAGNÓSTICO E PARTICIPANTES

7. O Novo Paradigma da Organização do Trabalho e a formaçăo

Profissional na Área da Saúde

Maria Umbelina Caiafa Salgado

8. Profissionalização de Trabalhadores de Saúde de Nível Médio:

Problemas e Desafios

Alina Maria de Almeida Souza

9. Debate

IV. A QUESTÃO TECNOLÓGICA E A QUALIFICAÇĀO PROFISSIONAL

10. CiênCia, Tecnologia e Qualificaçăo Profissional em Saúde

Marilia Bernardes Marques. 109

11. QualificaÇão Técnica e Qualificaçăo Social: EM Busca de Uma VISÃo Pós-habermasiana Rogério Valle

12. Debate 



\section{PREFÁCIO}

Em 1989, quando a Escola Politécnica de Saúde Joaquim Venâncio, da Fundaçăo Oswaldo Cruz, realizou o seminário Choque Teórico II, sobre o tema "Saúde, trabalho e formação profissional", colocava um desafio aos participantes: daquele evento deveriam brotar sementes de novas propostas para a formação de profissionais, para a superaçāo do conceito de que o trabalhador de saúde é um 'recurso' que dá sustentação ao sistema de saúde.

O seminário aglutinou um conjunto de profissionais comprometidos com um projeto educacional preocupado com o homem e não com o mercado de trabalho, em busca de referenciais capazes de resgatar a unidade entre teoria e prática, entre o saber e o fazer. Nele discutiram-se desde as concepçōes de saúde até a qualificaçāo necessária aos trabalhadores diante dos novos desafios tecnológicos colocados pela sociedade.

Nos debates, analisou-se a concepção médica sobre doença, que é a hegemônica, enquanto base para todo o processo tradicional de intervenção dos profissionais. "É preciso educar a população para, pelo menos, entender e saber tratar as doenças." A partir daí, se coloca a transmissão de determinado saber como finalidade da atuação profissional, sem que se considere a maneira como a sociedade (ou grupos dela) vê a questão e que códigos manipula.

Historicamente, as políticas públicas construídas em nosso país entenderam este binômio saúde-doença como uma dicotomia, fragmentando Saúde Pública e Medicina Curativa. Isto tanto do ponto de vista da articulaçāo entre os diferentes níveis de atenção, quanto no tocante à organização dos serviços e sua gestão pelas diferentes esferas de governo. Nessa maneira de ver, uma coisa é prevenir, cuja responsabilidade cabe a uma dada esfera de governo, e outra é curar, o que compete a outra esfera, as quais mantêm entre si permanente embate na obtençāo de recursos financeiros e de 'recursos humanos' para cumprir seus objetivos.

Discutiu-se também, no seminário, a privatizaçāo das açōes e serviços de saúde, ocorrida no Brasil, que fortaleceu a concepção do processo saúde-doença, 
voltada para a força de trabalho, bem como o princípio da lucratividade do trabalho de prestação de cuidados de saúde. Debateu-se, ainda, o processo de trabalho em saúde, considerando, em primeiro lugar, que ele é parte de um processo geral e, portanto, compartilha características comuns com os demais; em segundo lugar, que é um serviço que se funda numa inter-relação pessoal particular e intensa. Ademais, é fragmentado, ainda que integre os aspectos intelectual e manual, tendo na regulação de sua produção um de seus aspectos maịs complexos. Como atender, então, à intensa profissionalizaçăo e à exacerbada competitividade exigidas pelo processo produtivo atual?

E o seminário prosseguiu instigante, discutindo tanto a visão radical que separa a técnica da sociedade, quanto aquela que as funde, propondo uma compreensăo do relacionamento entre ambas, que possuem racionalidades próprias, mas se questionam permanentemente.

As apresentaçōes e os debates que se desenvolveram no seminário certamente alimentaram pistas e apontaram possibilidades que a Escola Politécnica de Saúde Joaquim Venâncio vem implementando, servindo de base para os que atuam no sentido de alterar o referencial tradicional da formação de profissionais. É um dos modos encontrados pela Escola Politécnica de pensar-fazer, aprender-ensinar.

Arlindo Fábio Gómez de Souza Sociólogo e sanitarista da Ensp/Fiocruz 


\section{APRESENTAÇÃO}

Decorridos tantos anos do evento que hoje nos é apresentado em forma de livro, julgamos pertinente compartilhar com o leitor os vestígios de uma história (estória?) que sobrevivem à leviandade de nossa memória, sempre, e cada vez mais, suscetível aos modismos e novidades. $E$, ingenuidade seria negar, vestígios marcados pela certeza do ineditismo dos que foram autores e personagens de um projeto nos primórdios de sua construção.

Contamos com a generosidade do leitor para com as paixões das que fazem esta apresentação. Todavia, reconhecemos, essa generosidade não precisará ser exagerada, pois, afinal de contas, sempre resta a certeza de que, nos textos que compõem este livro, está salvaguardada a objetividade da discussão.

Quanto à sua paciência... não podemos abrir mão. Paciência para atravessar esta apresentação, o prefácio, a introdução. Sem estes itens, isto que se apresenta não poderia ser reconhecido como um livro... Paciência (ou crença?) para com uma apresentaçāo realizada a seis mãos, em que três personagens daquele "contexto histórico" pretendem sintetizar os fragmentos da memória de um grupo de (ex)jovens, que, talvez por charme, ainda hoje se apresentam como inexperientes profissionais. Em comum, todas as personagens, provavelmente por falta de originalidade, no percurso destes sete anos que nos distanciam daquelas discussões, saíram em busca de 'novidades', e, inegavelmente, as versões que sobreviveram estão 'contaminadas' pelas 'novidades' apreendidas. Dito de outra forma, foram em busca do 'aprimoramento' profissional, e, nāo menos importante, não desistiram da briga pela 'busca de si'. Registramos a suspeita de que, por não serem 'competentes' o suficiente para escapar das marcas do tempo em que vivem, todas as personagens tanto falam de 1989 como de um passado longínquo quando ousam retratar aqueles anos idos, quanto o fazem a partir do presente.

Mas, por maior (ou menor) que seja nosso compromisso com a objetividade, não conseguimos nos subtrair da certeza de que a vitalidade que pulsa neste livro só 
poderá ser compartilhada se conseguirmos, mesmo que palidamente, transportar o leitor para as motivaçōes dos que, por privilégio, viveram aquele momento.

Do que trata o projeto? Do que fala este livro? Da "Escola Politécnica de Saúde Joaquim Venâncio: uma utopia em construção".

Mas não se iludam (ou, se for o caso, não se assustem), não foram poucos os questionamentos e conseqüentes discussões sobre a pertinência da expressão 'utopia'. Bobagens. $O$ termo ficou, e cada um acreditou na sua. $O$ que demostra a pertinência do termo.

A referida expressão foi título de um documento elaborado em 1987, quando da realização do seminário Choque Teórico I, dois anos após o início das atividades desta Escola.

Dentre outros temas e projetos discutidos por Sérgio Arouca, Arlindo Fábio e Luiz Fernando na comemoração pelo desafio de assumir a direção da mais importante instituição de pesquisas biológicas na América Latina, estava o de resgatar uma tradição iniciada por Oswaldo Cruz: a articulação entre a pesquisa, a produção, as atividades específicas dos senviços de saúde e o ensino. Era a partir deste princípio que a futura Escola deveria assumir a tarefa de coordenar e instituir a formação de profissionais técnicos na Fundação Oswaldo Cruz. Joaquim Venâncio seria o arquétipo (ou mito?) desse projeto.

$O$ que eu sei eu passo adiante - este foi o lema de um dos primeiros projetos assumidos pela Escola Politécnica, o Fazendo e Aprendendo. Um projeto que, dentre outros méritos, resgatou a tradição do princípio do trabalho fundamentado na relação mestre-aprendiz. Um projeto que nos permitiu constatar o orgulho do saberfazer dos marceneiros, tipógrafos, jardineiros, mecânicos etc. Da mesma forma, pesquisadores de diferentes laboratórios da instituição se dispuseram ao exercício da arte da iniciação de jovens adolescentes nos 'mistérios' da pesquisa cientíica.

Năo resistimos à tentação de demonstrar o quanto este foi um projeto pioneiro também no que se refere à preocupação com o social: a clientela era constituída por adolescentes, filhos dos funcionários que recebessem os menores salários na instituição, ou moradores das comunidades vizinhas. Os que participavam do projeto necessariamente deveriam comprovar suas matrículas na rede escolar de ensino e mensalmente recebiam uma bolsa de estudo. Caso o 'jovem aprendiz', por motivos justificados, estivesse afastado dos bancos escolares, a Escola ofertava a realização do ensino na forma supletiva.

Certamente, muitas das atividades desenvolvidas pela Escola Politécnica nos anos subseqüentes, como, por exemplo, o Programa de Vocação Científica e o Curso Técnico de Segundo Grau, em alguma medida, devem seus êxitos às iniciativas daquele projeto.

É importante destacar que os jovens adolescentes não eram nossa clientela exclusiva. Desde sua origem, a Escola desenvolve seu trabalho em duas vertentes 
principais: uma voltada para a formação de futuros profissionais e outra destinada à qualificação e atualização de profissionais já inseridos no mercado de trabalho. Eram tempos da VIII Conferência Nacional de Saúde, eram tempos de discutir a implantação da Reforma Sanitária do País, reforma esta que, pela particularidade do processo de trabalho que se realiza no setor saúde, impunha a atualização e revisão do processo de formação educacional dos profissionais que atuam neste setor.

Por ser mais prazeroso e sedutor, iniciamos o trabalho pelo resgate da tradição. Afinal, como resistir aos encantos de Ricamor (Ritamor?)? Como não nos apresentarmos àquelas milícias que durante anos, da planície, construíram e desconstruíram planos para a ocupação do Castelo?

Correndo o risco da indiscrição... é bem verdade que, decorridos poucos dias da ocupaçáo do Castelo, não foi difícil constatar a presença, dentre os sobreviventes que compunham a milícia, de marceneiros com alergia ao pó da madeira, entomologistas que nunca tiveram coragem de segurar uma barata, telefonistas surdas, sanitaristas que sabiam da existência de favelas por ouvir falar, porteiros mudos, assim como a inexistência de expertos em educaçăo.

Aprender-fazer-ensinar-saber-fazer-ensinar-aprender... Assim foram nossos primeiros tempos.

Não nos faltava bom humor e restavam-nos resquícios de exercícios de autocrítica, uma prática que imaginamos tenha algum grau de parentesco com os exercícios de autoflagelação, muito comuns em algumas das diversas seitas medievais. Ouvimos dizer que Maria Beltrão, com o grupo da paleoparasitologia, encontrou, em suas escavaçōes no campus de Manguinhos, alguns instrumentos que poderiam demonstrar que estes exercícios ainda eram praticados por contemporâneos de Oswaldo Cruz. Os trabalhos de interpretação ainda não foram concluídos, dizem, por culpa de um dos integrantes da equipe que insiste na hipótese de que estes eram instrumentos dos quais, vez ou outra, Ricamor lançava mão.

Quanto a nós, através desses exercícios de autocrítica e conforme os instrumentos que gradativamente estavam sendo introduzidos para avaliar a produtividade do trabalho desenvolvido, julgávamos que o desafio principal ainda não havia sido respondido: como atualizar o projeto de Oswaldo Cruz? Por quais caminhos, por quais referenciais teóricos responder aos desafios da formação de técnicos diante das transformações que ocorriam nos diferentes processos de trabalho neste final de século?

Não lembramos quem deu o nome, mas a busca de respostas a questões como estas nos levou à realização dos seminários denominados Choque Teórico / e Choque Teórico II, ocorridos, respectivamente, em 1987 e 1989. Provavelmente, o nome e a proposta surgiram por termos acreditado que corriamos o risco de excesso de pragmatismo, por estarmos excessivamente envolvidos pelas tarefas e paixões do cotidiano. Iniciava-se, de forma mais sistemática, a construção da prática da reflexão e formulação teórica dos trabalhos desenvolvidos pelos profissionais desta Escola. 
De qualquer forma, vista de hoje, a denominaçăo dada aos seminários nos parece extremamente adequada para marcar o ingresso da Escola no segundo dos desafios, a modernidade.

Resolvemos iniciar as discussōes pelo aspecto em que os indicadores, objetivos, sugeriam estar nossa maior fragilidade: os assuntos da educação.

Fomos adotando e sendo adotados por novos mestres: Joaquim Alberto Cardoso de Melo e Gaudêncio Frigotto. Pelas mãos deles, fomos ampliando nossos círculos de discussões. Nesse momento, fomos privilegiados pela interlocução com Dermeval Saviani, Miriam Jorge Warde, Nilda Alves e Zaia Brandão.

Mas, em um aspecto, quando da feitura desta apresentação, não conseguimos convergir para uma conclusão: não tivemos condições de avaliar se fomos excessivamente modernos ou se, apesar dos esforços, nunca o fomos.

O fato é que o documento através do qual imaginávamos estar ingressando na "modernidade", aquele que fala de uma utopia em construçäo, insiste em que determinadas certezas deveriam continuar pautando o trabalho realizado por esta Escola: a certeza de que, apesar do caos, desorganização e desmoralização que sofrem os serviços públicos no País, a Fiocruz é uma instituição respeitada pela populaçăo e seu compromisso principal é com essa populaçāo; um documento que afirma que o projeto da Escola Politécnica não pretende mais do que explorar todas as potencialidades 'pedagógicas' da Fiocruz, a fim de que a população, mais do que simples usuária dos seus serviços e produtos, de fato tenha acesso ao conhecimento que aqui é produzido; um documento que se insere no interior de uma conjuntura em que o debate da saúde e da educação se colocam como coisa pública.

Se tínhamos ilusões de que o seminário nos apresentaria respostas às questōes que a vivência do cotidiano do trabalho tinha apontado, rapidamente elas se dissiparam.

É bem verdade que rebuscamos nosso vocabulário, o que, por vezes, contribuiu para dificultar o diálogo, institucional ou pessoal. Passamos a falar de politecnia, de omnilateralidade, de reflexão da práxis, da divisão do trabalho intelectual e manual, da terceira (ou quarta?) revolução industrial. Afinal, a automação do processo de trabalho está a demandar maior ou menor qualificação do trabalhador? Mas, se a razão estiver do lado dos que concluem que este é um processo que acentua a desqualificação, como pensar a formação de técnicos em nivel de segundo grau de ensino?

De qualquer forma, delineava-se o horizonte das questōes a serem enfrentadas teórica e praticamente.

Sem considerar o tanto de convergência que possa existir no que se refere à definição das políticas sociais para as áreas da saúde e da educação, era preciso identificar os vasos intercomunicantes, no caso, definidores para uma proposta de formação de profissionais para o setor saúde. 
Explicitou-se o entendimento de que a categoria trabalho era o eixo definidor da construção de uma proposta curricular. Trabalho entendido como capacidade exclusivamente humana de transformar a natureza, uma capacidade que permite ao homem produzir e modificar suas próprias condiçōes de vida. Nas palavras de Dermeval Saviani, "é sobre a base do trabalho que surgiu a necessidade de conhecer a realidade e, portanto, a instrução e a educaçäo".

No mínimo, podemos testemunhar que o Choque Teórico 1 nos legou os seguintes desafios: definir uma proposta de formação profissional que buscasse a superação das dicotomias entre um ensino propedêutico e um ensino profissionalizante, entre a teoria e a prática, entre o saber e o fazer. Mas, acima de tudo, que os currículos e a prática pedagógica desenvohidos nos cursos realizados por esta Escola, fossem os de formação ou os de qualificação profissional, não perdessem de vista a formação do homem em sua integridade, visto que a competência técnica não dispensa, ao contrário, exige o domínio dos conhecimentos produzidos pela humanidade.

Em relação àquele primeiro seminário, podemos constatar importantes avanços. O principal deles reside no fato de que o leitor não precisa depender dos fragmentos de nossas memórias. Sobreviveu um 'fragmento' em forma de 'materialidade objetiva'. O que năo nos impede de insistir em que este livro deve ser entendido como a continuação daquele diálogo. Deve ser apreendido como um dos fios que ao longo destes anos tem tecido os caminhos da utopia que motivou a construção da Escola Politécnica de Saúde Joaquim Venâncio.

É com grande emoção que nós, integrantes da comissão organizadora do seminário Choque Teórico II, cumprimos o papel de apresentar o leitor às discussões travadas naquele evento.

Cidade de São Sebastião do Rio de Janeiro, novembro de 1996.

$$
\begin{array}{r}
\text { Bianca Antunes Cortes } \\
\text { Pesquisadora da Casa de Oswaldo Cruz/Fiocruz } \\
\text { Ignez Maria Ferreira Siqueira }
\end{array}
$$

Professora da Escola Politécnica de Saúde Joaquim Venâncio/Fiocruz

Lúcia Maria Dupret Vassalo do Amaral Baptista Professora da Escola Politécnica de Saúde Joaquim Venâncio/Fiocruz 



\section{INTRODUÇÃO}

O acelerado avanço científico e tecnológico que vem ocorrendo nas duas últimas décadas, com destaque para a crescente aplicação de um elenco de tecnologias referenciadas na microeletrônica, tem causado alterações significativas nas formas de organização do trabalho e nos processos de produção de bens e serviços.

Nessa transição, o modelo de produçăo em massa (taylorista/fordista) vai sendo substituído por um novo paradigma técnico-econômico, calcado na denominada "produção flexível", que se apóia, entre outras medidas, na reduçăo do tamanho das empresas, na terceirizaçăo das atividades como instrumento de absorção de mão-de-obra, na gestāo descentralizada, na organização nāo-hierarquizada. Essas mudanças têm repercussāo direta no perfil profissional do trabalhador, tornando necessário que, em sua formaçāo, adquira o domínio de técnicas diversificadas para atuar (e sobreviver) num contexto que faz emergir novas habilitaçōes e suprime outras, por obsoletas.

Em face desse panorama, a Escola Politécnica de Saúde Joaquim Venâncio, da Fiocruz, que se revela um espaço possível de reflexão, formulação de diretrizes e desenvolvimento de açôes práticas no campo do ensino técnico em saúde, realizou, em 1989, um seminário sobre o tema "Trabalho, saúde e educação", com o objetivo de pensar as transformaçōes que ocorrem no processo de trabalho em saúde, tendo por horizonte a implantação e consolidação do Sistema Único de Saúde.

A reálização do seminário constituiu importante e pertinente opção institucional, em especial pelo fato de a Escola procurar estabelecer e tornar real um processo de educaçāo politécnica que, como bem assinala Deluiz (1996:120), deve corresponder e expressar "a síntese dialética entre formação geral, formação profissional e formação política, promovendo o espírito crítico no sentido de uma qualificação individual e do desenvolvimento autônomo e integral dos sujeitos como indivíduos e atores sociais, possibilitando não só sua inserção, mas 
também a compreensão e o questionamento do mundo tecnológico e do mundo sociocultural que os circundam". 1

A Escola Politécnica tem a saúde como objeto-síntese e o ensino politécnico como especificidade de trabalho e, sem dúvida, o seminário representou uma relevante contribuição para se debater, de maneira comprometida, a realidade sanitária, instigando a construção/aproximaçăo de confluências entre a saúde e a educação, visando a formar pessoal de nível médio. Os textos deste livro expressam de modo crítico aspectos teóricos, ético-políticos e práticos desse processo.

Organizado em forma de mesas-redondas seguidas de debates, o seminário abrangeu quatro grandes temas: "Saúde: concepçōes e políticas públicas", "Relaçōes de Trabalho no Setor Saúde", "Formação Profissional: diagnóstico e participantes" e "A Questão Tecnológica e a Qualificação Profissional". As exposições foram gravadas, transcritas e editadas pelos organizadores do livro, sendo os textos, já em formato de artigos, submetidos a cada um dos autores para apreciação, adendos ou supressões, e aprovação. Igual procedimento foi adotado em relação aos debates, com os organizadores assumindo a responsabilidade de selecionar, dentre inúmeras perguntas/comentários dos participantes do seminário, aquelas mais relacionadas com as temáticas do evento. Apenas o artigo do professor Joaquim Cardoso de Melo, falecido em 27/06/93, não foi revisado por ele. Cabe ainda chamar a atenção para o fato de que, à exceção de um, os textos não incluem referências bibliográficas, tendo sido essa a opção dos próprios autores.

Saúde e doença como expressão cultural, de Maria Cecília Minayo, aborda a representação social de saúde e de doença, "entendendo concepção social como a idéia que fazemos a respeito de qualquer fato ocorrido na sociedade e vivenciado pelo indivíduo". As idéias, concepçōes ou representações que se estabelecem no imaginário social, elaboradas pela classe dominante, são reinterpretadas em cada segmento específico da sociedade. Essa reinterpretação, embora contenha elementos gerais das idéias dominantes, possui componentes culturais, etários, étnicos, econômicos, identificadores de determinado estrato social.

A autora reflete sobre as contradiçōes de nossa sociedade, na qual a doença é pensada a partir tanto do indivíduo e de causas endógenas a ele quanto da própria sociedade, do ambiente, das condiçóes de vida e de trabalho.

Na sociedade brasileira, "desigual, injusta e iníqua", a doença é tratada essencialmente como algo meramente orgânico, biomédico, separando o sujeito do seu contexto integral de vida. A doença é concebida como uma especialidade, e o corpo doente como o espaço da doença e não da vida; saúde seria o corpo em per-

1 DELUIZ, N. As mudanças no mundo do trabalho e no mundo vivido: conseqüencias para uma nova relação entre educação geral e formação profissional numa perspectiva de politecnia. In: Market, $W$. (Org,) Trabalho, Educação e Politecria. Campinas: Papirus, 1996. Da mesma autora, recomenda-se a obra Formaçäo do Trabalhador: produtividade e cidadania. Rio de Janeiro: Shape, 1996. 
feito funcionamento, mantido assim mediante o cuidado médico localizado, "capaz de intervir e consertar a máquina produtiva".

A autora chama a atenção para o fato de que a concepção de doença e a maneira de tratá-la observada na classe dominante também é aplicável à classe trabalhadora. Essa "ideologia da doença" se expressaria por meio das "doençasmetáforas" (como síflis, câncer, Aids). As "doenças-metáforas" incomodam e agridem mais a sociedade do que a morte pela fome, pela desnutrição, pela malária, pelos acidentes de trabalho, que, no entanto, ficam "subsumidas no quadro geral de preocupações da sociedade" por terem maior incidência sobre os trabalhadores de baixa renda.

Cecilia Minayo discute ainda o conceito de saúde coletiva, que se contrapõe "à visão medicalizada, que entende o setor como o conjunto de instituições e práticas curativas", incluindo também no texto elementos para uma discussão sobre as dificuldades das camadas populares para decodificar a linguagem médica, hegemônica, o que a induz a procurar uma expressão própria, assentada sobre a leitura que faz de seus valores, de sua vida e de seu corpo. Para essa população, não existe contradição entre o saber científico e o popular: ela relativiza e combina as formas e faz transparecer, na sua fala, o conceito ampliado de saúde, não se limitando (ou se contentando) em localizar a doença apenas no corpo.

O conceito de necessidades de saúde e as políticas sanitárias, de Hésio Cordeiro, explicita formas como a sociedade se organiza para atender às necessidades de saúde, enfocando-as em três dimensōes.

A primeira, a necessidade de saúde não é idêntica entre as pessoas de uma mesma classe e muito menos entre classes distintas, e essa visão particularizada repercute no modo como os indivíduos se relacionam com os seviços de saúde, sejam eles públicos ou privados.

Na segunda, a contraposição entre "o saber cientíico do médico, o saber dominante, e a concepção do indivíduo que recorre ao serviço médico" ocasiona uma dissimetria entre a linguagem médica (pela qual o profissional identifica e classifica determinada doença) e a forma pouco objetiva como o doente relata os sintomas do que o está afligindo.

A terceira diz respeito à necessidade de saúde do ponto de vista "dos planejadores de saúde, dos sanitaristas, dos profissionais de saúde pública", que usualmenté não coincide com o dos especialistas médicos.

Tendo em consideração as três dimensōes (ou percepçōes), o autor discute as políticas de saúde, alertando para a importância de entender política (ou políticas) como "um processo de contradiçōes e de relaçōes entre grupos que disputam o poder de forma distinta". Analisa o caráter excludente assumido pelas políticas públicas de saúde nas últimas décadas, que primaram por apro- 
fundar a dicotomia entre saúde pública e assistência médica, privilegiando a expansão do atendimento hospitalar privado.

$O$ autor menciona que essa dicotomia gerou uma fragmentação tão acentuada das políticas sociais no campo da saúde que a própria doença foi separada por nível de competência, ou seja, dependendo do tipo de doença, a responsabilidade e os cuidados deveriam ser assumidos por uma das esferas de poder (a federal, a estadual ou a municipal), traduzindo uma forma também desintegrada de cuidar do fenômeno vída e tornando distante a relação entre usuário (populaçăo) e o serviço de saúde. Ademais, ao se conceber a preservação e manutenção da saúde como imperativo para manter ativa ou restabelecer a força de trabalho, fazendo do indivíduo um recurso do capital, criou-se "um sentido de lucratividade do trabalho de prestação de cuidados de saúde". A saúde, além de restabelecer a capacidade de trabalho do indivíduo, tornou-se também objeto de lucro, de acumulação capitalista, "consubstanciado e estruturado na forma de empresas médicas".

De acordo com Hésio Cordeiro, a diferença de concepções tem refiexos diretos na própria organização do sistema de saúde, ocasionando desigualdades quer no acesso ao serviço, quer na qualidade do cuidado de saúde e na forma diferenciada com que, dependendo da classe social do doente, $\mathrm{o}$ atendimento médico é prestado.

$O$ autor elenca fatores que impulsionaram o movimento da Reforma Sanitária em nosso país com o objetivo de implantar um Sistema Único de Saúde, entre eles a necessidade de romper com a dicotomia entre saúde pública e medicina curativa (ou assistencial) e promover a "integralidade das açōes de saúde", destacando que a formulação das políticas de saúde deve ser traduzida na democratização do direito de acesso de toda a população a serviços de saúde de qualidade, dependendo seu êxito, na prática, da formação tanto técnica quanto política dos responsáveis por sua execução.

Educação e saúde: dimensões da vida e da existência humana, de Joaquim Alberto Cardoso de Melo, retoma o debate sobre os campos da saúde pública e da assistência médica, enfocando-os como um conjunto, pois separá-los seria reger-se por um raciocínio pontual e limitado, o mesmo que, aliás, estaria sendo aplicado para distinguir, enquanto setores autônomos, a educação e a saúde. Para ele, a questão deveria ser trabalhada pela ótica mais ampla das relações sociais, cujos embates e contradiçōes se projetam na organização social.

As interseções que vinculam, fazem interagir e resultam em movimentos e ações que repercutem no conjunto desses "campos". são indicadas em sucinto resgate histórico da saúde pública (inicialmente "ações de controle do Estado sobre o meio ambiente"), das mudanças de enfoque e de destinação, ao longo do tempo, de recursos financeiros para a saúde, de iniciativas que objetivam repensar um sistema com acentuados sinais de esgotamento. Estende sua reflexão ao papel da escola na formaçăo de profissionais para a saúde, situando-a tanto como um instrumento para atender ao mercado de trabalho, como um espaço onde se pode 
"apontar ou criar uma outra maneira de pensar a formação dos profissionais", escapando de um posicionamento de caráter passivo frente a imposições do mercado.

Alerta que "deve-se pensar a formação técnica profissional para além do âmbito da saúde e pensar saúde pública para além do âmbito da assistência médica", procurando encontrar limites e proceder a transformaçöes na relação homem/homem/natureza para preservar e manter a própria existência humana. Adverte que, se o discurso e a prática médica dominantes se fundam numa ordem biológica, a qual submete pacientes e profissionais de saúde, isto não significa que as pessoas estejam obrigatoriamente reduzidas a ela. $O$ agir social abriga e faz conviver outras ordens, outros discursos, variadas representaçōes, constituindo um complexo de relaçōes mais abrangente que pode incentivar e impulsionar movimentos que visem a mudanças, posto que a dimensão social, "com as representaçōes do que sejam ciência e técnica", comporta uma gama de relaçōes sociais intersubjetivas.

Por um viés filosófico, o autor acrescenta ainda elementos para pensar "saúde e educação como uma articulação com a vida e a existência", discorrendo sobre diferenciaçōes que determinam esses conceitos, reforçando a importância de se refletir sobre o que cada um deles (vida e existência) significa e representa na trajetória percorrida pelo homem para construir sua visão de mundo.

As dimensões do trabalho em saúde, de Roberto Passos Nogueira, inicia uma discussão a respeito do problema do trabalho em saúde, no qual destaca três aspectos fundamentais e interdependentes: a) inclui-se no conjunto dos demais processos de trabalho que ocorrem em outros campos e identifica-se com ele; b) distingue-se e caracteriza-se por ser um "serviço" que se realiza sobre pessoas e não sobre objetos; e c) é um serviço "que se funda numa inter-relação pessoal muito intensa", requerendo a participação e o envolvimento de quem consome e de quem presta esse serviço.

São destacadas como particularidades do trabalho em saúde "a tecnicalidade ou direcionalidade técnica inerente a qualquer processo de trabalho humano", mas que possui de específico uma "natureza coletiva", em razão da diversidade de atores que o ato técnico em saúde exige e comporta, o qual se desenvolve sob o comando e o controle do profissional médico. Em termos funcionais mais globais, é realçada a integração entre seus aspectos intelectual e manual, pois quem detém a direcionalidade técnica também "participa diretamente do ato técnico final". Por fim, destaca a marcante fragmentação dos atos técnicos, cuja tendência é se ampliar à medida que novas tecnologias vão sendo incorporadas e utilizadas no processo.

$O$ autor instiga a refletir quanto a competências técnicas e postura ética requeridas do profissional que atua nessa área em que múltiplas intervençōes são realizadas de maneira pontual no corpo do doente (que comumente ignora a finalidade de tais intervenções e não é esclarecido sobre elas). Para subsidiar a reflexão, Roberto Passos Nogueira - partindo de definição genérica postulada por Marx - aprofunda o questionamento em relação ao que vem a ser "serviço de 
saúde", destaca-o de outros tipos de serviços e, com isto, insere indagações para um debate a respeito da natureza econômica desse serviço, abordando a questão da remuneração e do controle do ato médico. Ressalta também a relevância do diálogo que deve necessariamente se estabelecer não apenas entre o profissional da saúde e o doente, mas também entre o coletivo dos trabalhadores da saúde e os usuários dos serviços.

O novo paradigma da organização do trabalho e a formação profissional na área da saúde, de Maria Umbelina Caiafa Salgado, situa as especificidades da formação profissional na área da saúde, "dentro do quadro econômico, político e social do País." Considera que as questões do trabalho, da participação e da cidadania devem ser discutidas a partir da análise da organização do processo de trabalho e das relações sociais subjacentes.

Mostra que o Brasil, como país periférico, sofre as contradições e desequilłbrios de uma modernizaçăo dependente e que, como em outros países subdesenvolvidos, a decisão de internacionalizar a economia conduz a um processo de oligopolização, em um movimento oposto ao ocorrido nos países do chamado Primeiro Mundo, onde a oligopolização alavancou a internacionalização. Se, nos países de economia avançada, o processo de concentração de capital demorou séculos, nos denominados de Terceiro Mundo ele se deu em poucas décadas, resultando num quadro muito mais dramático, mais selvagem, num choque violento e perverso.

Discorre sobre o esgotamento do modelo da produção em massa e a transição, que atualmente acontece, no sentido da adoção de um paradigma assentado na produção flexível, isto é, "năo mais se aumenta a planta da fábrica, mas criam-se pequenas empresas autônomas, embora do mesmo grupo, que prestam serviços à empresa maior". Esse modelo, além de reduzir custos e aumentar a produtividade e o lucro, segmenta e enfraquece a organização dos trabalhadores, proporcionando um controle maior da força de trabalho por parte dos detentores dos meios de produção.

A autora alerta para o significado novo que, diante desse cenário de transição, assumem as relações entre educação e trabalho, destacando a importância dos "conceitos de requalificação, reprofissionalização e politecnia". Indicando contradiçōes na crise de paradigmas que se vêm instalando e entendendo que a definição dessas contradições é de caráter político, chama a atenção tanto para a educação básica e sua importância para a cidadania como para o papel do ensino e do profissional técnico (em especial em áreas "de interesse claramente coletivo", como educação, saúde e saneamento), numa situação de significativas mudanças políticas, econômicas, sociais e culturais.

Profissionalização de trabalhadores de saúde de nivel médio: problemas e desafios, de Alina Maria de Almeida Souza, discute a formação de pessoal técnico para a saúde diante da conjuntura nacional e das diretrizes e propostas do movimento da Reforma Sanitária. Assinala que as possibilidades e alternativas de mudança na saúde requerem, fundamentalmente, opção e decisão de cunho político, visando a 
enfrentar e a alterar o real. Isto porque a luta dos profissionais que têm a perspectiva da saúde pública aponta para um reordenamento da sociedade, que, hoje, apresenta e discute um projeto incompleto de Sistema Único de Saúde e vivencia uma prática de saúde predominantemente privatista.

Alina Souza explicita dificuldades a serem superadas e acrescenta que, para a consecução do sistema pretendido, "a profissionalização na área da saúde deve avançar em duas direções: qualificar os trabalhadores e formar novas gerações de técnicos para ingressar no setor", criando compromisso e ampliando a consciência sanitária desse contingente. Nesse horizonte, defende uma articulaçăo maior entre a educação e a saúde, para que, de modo conjunto, sejam pensadas e implementadas metodologias para profissionalizar os trabalhadores e desenhar processos metodológicos que possibilitem aos jovens da escola regular "iniciar seu processo de profissionalização antes de integrar-se à força de trabahiho", o que implicaria aliar ensino/serviço, ensino/trabalho. Esse seria, pois, o 'desenho' e os objetivos de uma escola técnica de saúde: "que recupere e legitime os que já estão trabalhando sem preparação específica e que forme novos profissionais para o mercado", tendo em vista as necessidades do Sistema Único de Saúde.

A autora expõe que um dos grandes desafios de uma escola técnica de saúde é trabalhar com a realidade da saúde, com "toda a prática específica acumulada e a necessidade de sua revisão", sem perder a dimensão dos aspectos coletivos do conhecimento, de modo a consubstanciar o ensino da cooperação e o sentido de equipe de trabalho nas especificidades de cada um dos campos técnicos.

Ciência, tecnologia e qualificação profissional em saúde, de Marília Bernardes Marques, remete ao debate das implicaçōes das novas tecnologias no mundo do trabalho, indicando mudanças que a sua incorporação e utilização promovem na divisão social do trabalho e nas características da força de trabalho.

Relata que a inexistência, no Brasil, de "estudos setoriais que forneçam uma base empírica" restringe, obrigatoriamente, a possibilidade de realizar uma análise mais acurada sobre o assunto e aborda o problema a partir das características e condições de nosso país subdesenvolvido. Utilizando indicadores numéricos, realça a baixa escolaridade da população, a "acentuada tendência de queda" da taxa de formalidade no mercado de trabatho e a conseqüente redução da renda do trabalho na composição do Produto Interno Bruto, destacando o flagrante aumento da concentração de renda, o que amplia e agrava ainda mais a situação de miséria social.

Explicita que o Brasil precisa formular, com urgência, um modelo de desenvolvimento que, para se tornar viável, deve ter como referência "a modernização tecnológica, a distribuição de renda e a democracia", proporcionando o crescimento econômico e o atendimento às necessidades sociais requeridas pela população e utilizando, de maneira equilibrada e não-predatória, os recursos naturais de que o País dispōe. Para escapar de um modelo dependente e perverso, propōe a alternativa de transformar a estrutura social "a partir da tecnologia, 
ajustada a uma demanda do mercado interno que resulte da ampliaçāo de programas sociais e da elevação de salários reais".

A escolha tecnológica correta se coloca como o desafio com que o País se defronta, e essa é uma decisão política que implica optar por uma modernidade técnica ou ética. A mudança ou progresso tecnológico possuem condicionantes sociais e políticos, são produto de relaçōes sociais determinadas e "marcam profundamente os trabalhadores por meio das alterações que promovem na natureza e nas relações de trabalho". Tais modificaçōes no processo de trabalho compreendem limites dados pelas relaçôes entre capital e trabalho e pela atuação do Estado, por meio de políticas públicas.

Nesse contexto de transição, a autora ressalta que a formação profissional na saúde tem que estar perpassada pela problemática da incorporação e utilização de novas tecnologias, pois estas diversificam e alteram a importância das ocupações (criando e valorizando novas e tornando obsoletas outras), exigindo do trabalhador maior qualificação e tempo de escolaridade. A formação técnica deve contemplar a apropriação e o domínio de habilidades específicas, sem que isto signifique reduzir ou eliminar a posse, pelo indivíduo, de uma sólida formação geral.

Qualificação técnica e qualificação social: em busca de uma visão pós-habermasiana, de Rogério Valle, analisa a qualificação ségundo o desenvolvimento histórico da teoria e sua inserção na prática. Nessa perspectiva, ressalta que, em dado momento, a técnica se constituía enquanto autônoma em relaçāo às "opçōes políticas e às características culturais de uma sociedade", com a evolução desta subordinada e condicionada a um determinismo técnico. Avalia que o ponto de ruptura com essa visão foi a reflexāo da Escola de Frankfurt, que atribuía ao desenvolvimento técnico e científico um papel cerceador à evolução da sociedade, passando a considerar técnica e ciência como fatores de opressão.

Do ponto de vista do autor, ambas as visōes - técnica divorciada da sociedade e técnica como instrumento de dominaçāo - "parecem inadequadas", porque "exclusivamente sistêmicas": ou a sociedade é um sistema social caracterizado por um "desenvolvimento tecnológico intenso", ou é submetida a um processo regulador da técnica, cujo predomínio não admitiria resistências. Assinala que a sociedade não é apenas "uma grande máquina", pois se por um lado é um sistema, por outro é um "mundo da vida", elaborado e construído a partir da experiência vivenciada que confere às pessoas capacidade e lucidez suficientes para não se conformarem, para se aperceberem de que "a opressão e a resistência, o positivo e o negativo, a dor e a alegria, o trabalho e o lazer" convivem e interagem. Isto confere à sociedade uma dinâmica que a faz superar pretensōes de demarcar limites. O ideal seria "reunir a perspectiva sistêmica e a do mundo da vida" num processo comum de construçāo.

$O$ autor acrescenta ser preciso evitar duas formas do que denomina "deformação ideológica": buscar legitimar decisōes políticas por meio da técnica, bem 
como assumir um "voluntarismo político que julgue poder passar por cima de assuntos que requerem reflexão propriamente técnica". São duas racionalidades - a técnica e a social - que se questionam de modo permanente, e é no nível da experiência, da prática empreendida com suficiente e equivalente conhecimento e compreensão dessa problemática, por parte dos sujeitos da ação comunicativa, que se criam condições para que se estabeleça o equilíbrio entre as duas esferas.

Este livro, a nosso ver, é um conjunto de inquietaçōes e questionamentos ainda em busca de superação. É nossa convicção e nosso desejo que ele seja útil para ampliar o debate sobre alterações necessárias no processo de formação do profissional de nível médio para a saúde, contribuindo como subsídio na formulação de propostas educacionais que tenham o trabalho como orientador e emancipador das ações humanas.

Os Organizadores 



\section{SAÚDE:}

CONCEPÇÕES E POLÍTICAS PÚBLICAS 
<smiles></smiles> 


\title{
SAÚDE E DOENÇA COMO EXPRESSÃO CULTURAL
}

\author{
Maria Cecília de Souza Minayo
}

Concepçōes e representaçōes como integrantes da realidade social

Pretendo discutir a questāo da representaçāo social de saúde e doença, apresentando alguns elementos conceituais para refletir sobre o assunto, não do ponto de vista histórico, mas do ponto de vista social, entendendo concepçāo social como a idéia que fazemos a respeito de qualquer fato ocorrido em sociedade e vivenciado pelo indivíduo.

O homem é um ser que, ao mesmo tempo, cria cultura e simboliza suas vivências, sendo capaz de expressá-las. A expressão dessas vivências é que constitui a representação social, que possui sempre elementos conscientes e inconscientes. Assim, não preciso, necessariamente, elaborar ou redefinir a idéia que tenho de mulher, de trabalho, de religião, de espaço, de tempo. Ela está presente e é histórica e socialmente construída. A idéia de tempo que atualmente possuímos, por exemplo, corresponde à concepção dominante de que tempo é dinheiro, tempo se gasta, se aproveita, se desperdiça.

Nós marcamos e dividimos o tempo, espaçamos o dia diferentemente da sociedade da Idade Média ou de uma sociedade primitiva. Nós nos localizamos e nos organizamos de uma dada forma, concebemos o espaço econômico de uma certa maneira, e assim por diante. Segundo Marx (1980), essas idéias, concepções ou representações não são necessariamente conscientes. Em uma sociedade dividida em classes, elas sāo construídas pelas classes dominantes. No entanto, essas concepçōes, marcadas pela ideologia dominante, são reinterpretadas em cada segmento específico da sociedade. Por exemplo, a idéia que eu possa ter de vida e morte - embora contenha elementos gerais das idéias dominantes - possivelmente não será idêntica àquela que possuem os componentes da classe trabalhadora pobre, porque cada elemento da nossa representação social é reinterpretado pelo grupo a que pertencemos, pela vivência que temos na so- 
ciedade. Da mesma forma, essa reinterpretação terá um viés cultural de gênero, de idade, de pertinência a determinado país, grupo étnico etc.

A concepçāo, a visão de mundo é, pois, composta das idéias dominantes em determinada sociedade. Weber (1974) afirma que, em qualquer sociedade, haverá sempre idéias dominantes. Desse modo, seria impossível viver o capitalismo sem a idéia de espaço e de tempo dominantes na sociedade. Embora se possam reinterpretar de alguma forma, essas concepções sāo uma mistura das idéias filosóficas de nosso tempo, uma mistura do próprio senso comum que é elaborado através da experiência dos diversos grupos sociais, vivenciadas no plano das contradições. Por isso nossas representaçōes sociais, nossas concepçōes sociais são capazes de revelar a natureza contraditória da sociedade em que vivemos, do grupo social que freqüentamos e, de certa forma, representamos.

Do ponto de vista mais geral, a representação social não é meramente uma opinião, a opinião a integra. A maneira como se constrói um hospital ou um centro de saúde, de certa forma, cristaliza uma representação social própria de saúde e doença. Num hospital em que a enfermaria de pediatria só possui espaço para a criança sozinha, desacompanhada da mãe, está-se expressando um tipo de concepção de saúde e doença que pode ser resolvida apenas por intervençōes médicas. Ou seja, na concepçāo dominante, saúde e doença são algo organicamente localizado, a ser tratado por meio de um medicamento, de uma cirurgia. Esse é o modelo biomédico dominante em nossa sociedade.

Thomaz (1963), renomado fenomenologista, afirma o seguinte: "O problema das idéias que a gente tem, o problema das questōes que a gente pensa é que aquilo que a gente pensa é real nas suas conseqüências." Chamo a atenção para isso porque, em determinadas correntes de pensamento, há uma tendência a valorizar, isoladamente, ora a idéia, ora o fato material. Parto do princípio de que uma concepção social ou uma representação social é capaz de revelar a natureza contraditória da realidade: ela une a base material e a idéia que vigora na sociedade. Se a idéia influencia a base material, esta, por sua vez, também repercute na elaboraçāo das concepções vigentes.

\section{Concepções sociais de saúde e doença}

Do ponto de vista da saúde-doença, embora esse binômio acompanhe nossa existência desde que o homem é um ser social, pensar esse fenômeno como um fato social, como uma questăo de interesse maior para a sociedade, é um enfoque recente para o qual tem sido decisiva a contribuição de sociólogos e antropólogos. Significa refletir que a doença, além de ser um fato biológico, é uma realidade construída tanto historicamente, como dentro da expressão simbólica coletiva e individual do sujeito. O antropólogo Lévy-Strauss (1970) chama a atençāo para isso ao 
afirmar que a dor que sentimos, o esforço que julgamos passivel ou não de realização é muito mais função de uma criação social do que de uma realidade do nosso corpo. Isto é, o corpo é capaz de executar determinados atos que a sociedade julgue que ele é capaz de fazer. Esse mesmo enfoque é dado quando ele aborda o problema do racismo, ao dizer que a questão da cor - como elemento importante para avaliar a capacidade de um ser humano - também é uma realidade construída.

Portanto, em que sentido se pode pensar o fenômeno saúde e doença do ponto de vista mais geral e, depois, pensá-lo mais especialmente para a sociedade? Pelo fato de saúde e doença estarem vinculadas a duas questōes fundamentais para todos nós - a vida e a morte -, poderíamos dizer que a concepção de saúde e doença é particularmente reveladora do grupo social. Ela mostra, de forma muito especial, como o indivíduo se situa na sociedade e como esta se situa em relação ao indivíduo. Ou seja, construímos um discurso social-histórico sobre saúde e doença, um discurso social-histórico sobre o corpo e um discurso sobre a vida e sobre a morte. Saúde e doença, portanto, não são apenas efeitos biológicos, mas também acontecimentos culturais historicamente construídos de diferentes formas em diferentes sociedades.

Nossa sociedade capitalista, marcada pela desigualdade, tem uma concepção de saúde e doença que expressa a natureza contraditória da própria sociedade. De modo geral, pode-se dizer que o tema da doença costuma ser tratado, algumas vezes, a partir do indivíduo e de causas endógenas a seu organismo e psiquismo, e outras, a partir da própria sociedade, do ambiente, das condiçōes de vida e trabalho. Quando proveniente do indivíduo, a idéia de doença inclui questões como, por exemplo, o fatalismo. Muitas vezes, é explicada também de forma transcendental e não apenas pela ótica social. Nessa visão de fatalidade, de desperdício da saúde pelo sujeito, atribui-se a ele, quase sempre, a culpa pelos problemas que o acometem.

A explicação pelo enfoque mais social da saúde inclui, particularmente, a questão do modo de vida como algo externo que provoca a doença. Por esse ângulo, concebe-se a poluição atmosférica, a violência, o estresse, o ritmo de trabalho e o ambiente familiar como elementos prejudiciais à saúde.

Existe aí uma contradiçāo: a saúde é fator, é função do indivíduo, mas o modo de vida é de tal forma 'adoecedor' que prejudica a saúde das pessoas. Atualmente, existe uma tendência a explicar a saúde como um bem que o indivíduo pode perder; bem cujo capital inicial é devido a uma infância bem nutrida; e a doença, por sua vez, como resultante do modo de vida. Pensando, porém, de forma dialética, há sempre uma ligação entre o indivíduo e a sociedade, entre o indivíduo e a qualidade de vida. A própria 'biologia' trabalhada pela sociedade cria, como diria Marx, uma 'segunda natureza'.

Cabe então indagar: - Que modo de vida externo é esse que parece capaz de neutralizar o sujeito da ação? Do ponto de vista das classes médias, Herslish (1983) detecta a explicação do modo de vida como algo fetichizado, concebido 
como fora de nós, a-histórico, que nos prejudica como se fôssemos vítimas incapazes de mudar a realidade. É uma explicação bastante positivista e estática da doença.

$\mathrm{Na}$ nossa sociedade capitalista, desigual, injusta e iníqua, para pensar saúde e doença, têm-se que assumir as contradiçōes geradas pelas desigualdades econômicas, políticas, sociais e ideológicas, que se expressam nas concepções e práticas de saúde e doença. Nessa sociedade contraditória, saúde e doença sāo pensadas, em primeira instância, como fatores de produção, e o sistema de saúde é organizado de forma a tornar o indivíduo produtivo. Assim, se uma pessoa tiver uma crise depressiva ou algum outro problema de ordem emocional, ao solicitar um atestado médico num posto de saúde, para nāo ter descontado um dia do salário, possivelmente nāo obterá o documento. Isto porque năo tem uma doença localizada no corpo. Certamente, dirão: "Você pode trabalhar, isso é problema da sua cabeça, você tem que reagir".

A concepçāo de doença é a localizada no corpo, uma concepção biomédica e que se encontra vinculada à questão da produção. A morte é pensada como uma parada de funcionamento do organismo, e a vida equivale a ter saúde, isto é, ao bom funcionamento de todos os órgāos do corpo. Grosso modo, a concepção biomédica reduz a doença e a saúde ao contorno biológico individual, separando o sujeito de seu contexto integral de vida.

Quando uma pessoa procura o médico, este não quer saber de que ambiente ela vem, que problemas enfrenta. Importante é localizar a doença, entendida como uma especialidade, e o corpo doente é encarado como espaço da doença, e não como espaço da vida. Em última instância, vai-se cada vez mais sofisticando uma linha de especialização (e de fragmentação) que concebe a doença por meio das mensagens infracorporais fornecidas pelos exames. A saúde seria o reverso, seria o corpo em perfeito funcionamento. Para a visão dominante, o importante é o cuidado médico fragmentado, localizado, capaz de intervir e consertar 'a máquina produtiva'.

Essa concepção médica é a mesma tanto para a classe dominante quanto para a classe trabalhadora, até para seus estratos mais baixos. Mas a classe dominante usa outros recursos, tem seus cuidados para proteger aquele 'capital inicial', aquela acumulação primitiva de saúde que daria sustentação ao corpo. Ela está mais vinculada a uma visão global, que inclui lazer, cuidados corporais, assistência aos sofrimentos emocionais, potencialização do espaço e do tempo de vida. Os cuidados médicos para a classe dominante incluem um leque de possibilidades que não estão disponíveis para outros grupos.

A classe dominante está mais preocupada em analisar o modo de vida enquanto opressor por si mesmo, sem sujeitos: "Estamos numa sociedade na qual a violência, o ambiente poluído, as relações estressantes não têm jeito, os conflitos são muitos, nós somos vítimas". É como se houvesse algo externo prejudicando, mas algo que não tivesse solução. 


\section{A doença como metáfora}

Gostaria de reforçar que a concepção de doença (não de saúde) observada na classe dominante, bem como a maneira de tratá-la, é a mesma que se aplica à classe trabalhadora. É a doença biomédica, localizada nos órgãos e, particularmente, aquela que busca mensagens infracorporais. Penso que a forma mais concreta dessa 'ideologia da doença' se expressa por meio das chamadas 'doenças-metáforas', que simbolizam fortemente o tipo de sociedade em que ocorrem, inclusive pela falsa idéia de que elas ultrapassam a questão de classe. A Aids, o câncer e, nas sociedades mais antigas, a sífilis são doenças que, para a sociedade, atingiram indiscriminadamente todas as classes. Não é bem verdade, mas, como elas alcançam também a classe dominante, tornam-se muito chocantes para a sociedade, que imediatamente reage frente a elas. Numa perspectiva sociológica, elas apareceriam como uma espécie de anomalias sociais e indicariam desordens, desvios, devassidão, limite e incapacidade do ser humano diante do mal. São doenças que remetem à morte, e, diante delas, a sociedade reflete sobre o seu próprio desaparecimento. Isso se expressa de forma muito particular nas teorias milenaristas e nas religióes e crenças populares.

Segundo Sontag (1984), "essas doenças-metáforas fazem cóm que nos encontremos com a nossa concepção arcaica e moderna de mal". Trememos diante delas porque assinalariam um limite humano, nos colocariam o desafio da própria capacidade de sobrevivência. São, portanto, metáforas da sociedade, metáforas muito fortes de tudo aquilo que, também individualmente, se acha colocado para nós. Para o sistema médico, em especial, elas também expōem o desafio e o limite de suas potencialidades. Contraditoriamente, porém, ao mesmo tempo em que se depara com o limite, o sistema médico dominante reforça uma ideologia muito própria, que é a de vencer a doença. Essa sensação de onipotência é uma concepção do médico em relação à sua função e em relação à saúde e doença na sociedade. Ou seja, ante o desafio, a corporação reafirma a ideologia de que um dia a morte será vencida.

O que é interessante em relação a essas doenças-metáforas é que elas se contrapõem a doenças muito próprias das populaçōes trabalhadoras e de baixa renda. Sabemos que hoje, no Brasil, a Aids mata muito menos que a fome, pois a mortalidade infantil, tendo a desnutrição como causa associada, é muito grande. Por ano, são registrados 650 mil novos casos de malária, 250 mil novos casos de hanseníase, a desnutrição ameaça a vida de cerca de trinta por cento das crianças brasileiras. Mais de um milhão de acidentes de trabalho e doenças profissionais atingem os brasileiros anualmente, com cerca de cinco mil mortes por essa causa. No entanto, elas não mobilizam, não são contempladas por nenhum discurso político em favor da saúde. 
A contradição é que a doença, enquanto expressão das condiçōes adversas de vida e trabalho, é discriminada inclusive pelo próprio sistema médico, que se abstém de enfrentá-la. As enfermidades próprias do trabalho, da desnutrição, da fome, que atingem desde as camadas riłais pobres até o operariado, ficam de certa forma subsumidas no quadro geral de preocupações da sociedade.

Recordo que, num curso de especialização ministrado no Acre, deparei-me com um mural de informaçōes repleto de dados sobre Aids, embora a incidência da doença naquele estado fosse nula na época. Um dos exercícios realizado no curso foi estabelecer um quadro epidemiológico da regiăo, ainda que de modo superficial. No trabalho, foi observado o elevado número de acidentes de trânsito e a altíssima incịdência de malária. Diferentemente da Aids, esses agravos à saúde não haviam recelsido nenhum destaque.

Nosso imaginário social é marcado por essas doenças que aparecem de forma muito gritante, fazendo com que sejam encaradas como prioritárias, mesmo não constituindo um problema local, isto é, uma situação de fato.

\section{A concepção de saúde-doença das camadas populares}

Corn relação às camadas populares (consideradas aqui como o conjunto da população de baixa renda), a concepção de saúde e doença, de acordo com o exposto anteriormente sobre representação social, é contraditória. Numa primeira instância, elà támbém assume a questāo da produção. Um estudo que realizei junto a seis favelas do Rio de Janeiro sobre representações sociais, saúde e doença demonstrou que os moradores entrevistados expressavam a concepção dominante nesse campo, ou seja, doença como impossibilidade de trabalhar, de realizar os af́azeres rotineiros e cotidianos.

As pessoas diziam que, quando ficarn "perrengues" e não conseguem trabalhar, "a gente fica quieto, fica parado". E, se perguntadas quando percebem que uma criança está doente, a reflexão é mais ou menos na mesma linha: pela falta de atividade, pelo fatu de a criança ficar quieta, calada, parar de brincar. A representação scicia! de saúcie e doença, portanto, está muito ligada à atividade física e à capacijade para trabalhar.

Essa equivalência da doença ao não-trabalho ou à não-atividade não é natural, mas sociaimente construída de acordo com a ideologia de que nosso corpo é feito para produzir. Produção essa que, para a classe trabalhadora, tem um valor estipulado sob a forma de salário. É uma equivalência construída com base na realidade social, pelo modo de produçāo vigente. Os trabalhadores sabem disso na şọ́̂tia rarne: se não trabaiham, nāo têm o que comer. Saúde, doença e trabalho 
constituem, portanto, uma interdependente e cotidiana relação, que pode ser traduzida pela própria concepção da vida.

A classe dominante possui uma dissimetria em relação à linguagem médica. Não sabe, nem tem necessidade e capacidade para conhecer termos médicos. Mas, se uma enfermeira, por exemplo, 'traduz' determinado vocábulo técnico em linguagem coloquial, qualquer membro da classe média ou das elites é capaz de entender do que se está falando, porque a visãc de mundo é semelhante.

Essa dissimetria da linguagem pode ser considerada para os estratos da classe dominante, mas, para a classe trabalhadora, não se resume apenas ao problema de linguagem. Há uma oposição de valores que está muito mais ligada à categoria de vida, à própria expressão que a classe possui de saúde e doença.

Ao mesmo tempo em que a classe trabalhadora usa a não-atividade para falar de doença, ela utiliza, ainda que erroneamente, expressōes anátonio-fisiológicas para falar sobre o assunto, de certa maneira copiando o discurso médico. Sabe nome de remédio, repete nome de doenças e reinterpreta diagnósticos feitos pelo médico. Isso já foi obsenvado e pesquisado tambéín for Boltanski na França (1984). Por outro lado, essa classe tem uin outro código de leitura de seu corpo, de seus valores, de sua vida, e isso coloca os médicos $\mathrm{cm}$ xeque. Sobretudo porque a doença é explicada por meio de condições existenciais oil, às vezzss, de intervençōes sobrenaturais. Na verdade, quando está falando de doença, a populaçăo está se referindo a um conjunto de sıtuaçōes infelizes na sua vida, enquanto ao médico interessam, para diagnóstico, os sintomas que configurem a doença enquanto ente biofisiológico.

Há, pois, duas concepçōes em jogo: uma hegemònica, a médica; a outra, que vem tentando se expressar. Muitas vezes, os médicos vão dizer: "É preciso educar a populaçāo para, pelo menos, entender e saber tratar as doenças". Mas năo basta educar a população neste sentido de intervenção. É preciso entender como ela vê a questão, qual o seu código, sem perder die vista que nas concepçôes sociais de saúde e doença existe bom senso tanto da parte do médico quanto da população. Seria importante para o médico perceber o grau de born senso contido nas queixas do paciente, porque esse discurso diferenciado é uma linguagem de uma classe que expressa conflitos reais, que se forma nas condiçôes de vida e que condensa vários tipos de experiências. É agir de maneira preconceituosa considerar que a classe trabalhadora năo sabe explicar sua doença e saúde. Sua linguagem própria reflete o saber da experiência e, inclusive, contém muitos elementos do esquema médico dominante. A população pobre que vai aos centros de saúde, aos hospitais, desconcerta o médico, porque questiona o seu saber, relativiza-o e o combina com muitas outras crenças e práticas. Desconcerta-o também porque traz para o campo. dito científico, a eficácia simbólica já tratada e creditada pela antropologia (Lévy. Strauss, 1970: Douglas, 1970; Minayo, 1994). 
Para essa classe, o médico é um intermediário de suas carências, e a passividade diante do sistema médico é uma forma de resistência. A mãe que leva o filho ao médico freqüentemente está dizendo alguma coisa e é preciso entender isso. Ao solicitar um remédio, ela também está expressando o seu pedido de socorro e de mediação. É dessa forma que exprime suas necessidades, insegurança e impotência. Mas, por outro lado, ela busca outros meios, como a 'medicina caseira' e as práticas terapêuticas religiosas. Para a população pobre, nāo existe a menor contradição entre ir ao médico e, logo em seguida, procurar uma rezadeira. Ela acredita no médico, mas não totalmente, assim como também não acredita totalmente no padre ou na rezadeira. Ela combina as formas, porque esses 'especialistas' the dão respostas diferentes.

O que se observa nessas camadas populares é que elas não restringem a doença ao ponto de vista biomédico, mas têm uma concepção de saúde e doença muito mais ampla. Relacionam a questão da infelicidade, do modo de viver, com a ecologia ao se referirem ao ar impuro, à vala negra, às mudanças no tempo, assim como ao mau-olhado, à 'coisa feita' ou a outras interferências. Elas reclamam da alimentação, do salário, das condiçōes de trabaiho, e assim todo o chamado conceito ampliado de saúde transparece na fala de qualquer pessoa dos estratos populares.

\section{A saúde coletiva enquanto conceito contraditório}

O conceito de saúde coletiva (que hoje fundamenta a própria política de saúde) enfoca a saúde sob um prisma abrangente, que inclui trabalho, lazer, alimentação, condições de vida, indo ao encontro tanto da fala experiencial, vivida, da classe trabalhadora, como da fala mais organizada dos sindicatos, que expressam o pensamento mais elaborado, via intelectuais orgânicos dessa classe. O que se percebe no movimento da saúde coletiva é o seu caráter minoritário, de resistência, diante da visão medicalizada que entende o setor como o conjunto de instituições e práticas curativas, haja vista a baixa remuneração dos que atuam nos programas preventivos e de atenção básica e a alta proporção do orçamento voltada para as atividades curativas.

É importante observar, porém, que, do mesmo modo, o modelo filosófico da saúde coletiva apenas toca na questão cultural das representações e da fala dos diferentes grupos sociais para considerá-las integrantes do paradigma de saúde e doença. Essas concepções, formadas pela experiência de vida, são parte do esquema que produz a cura dentro da realidade social.

As camadas populares invocam Deus na saúde e na doença, mas isso não significa que elas expliquem a doença apenas por meio da religiăo. Não existe essa oposição. A etiologia popular explica saúde e doença por condiçōes de vida, por questóes emocionais, salariais, religiosas. Quando fala em Deus, é sua forma de 
chamar a atenção para alguma coisa que o sistema de saúde não capta. Isto porque a doença é algo mais integral, dá em gente, e gente não é só corpo, gente é muito mais que isso: é parte de um ecossistema integrado e um sistema social carregado de contradições e possíveis consensos (Minayo, 1988).

O grande desafio da saúde coletiva é essa concepção mais abrangente que integra as políticas sociais, as condições de vida e também a sensibilidade para a riqueza e a diversidade cultural.

\section{Referências Bibliográficas}

Boltanski, L. As Classes Sociais e o Corpo. Rio de Janeiro: Graal, 1984.

Douglas, M. Pureza e Perigo. São Paulo: Perspectiva, 1970.

Herslish, C. Santé et Maladie. Paris: La Haye Mouton, 1983.

Lévy-Strauss, C. Magia e religiāo. In: Antropologia Estrutural. Rio de Janeiro: Tempo Brasileiro, 1970.

Marx, K. A ideologia alemã. In: Obras Escolhidas. 2.ed. São Paulo: Alfa e Ômega, 1980. Minayo, M. C. S. Uma concepção popular da etiologia. Cadernos de Saúde Pública, 4(4): 363-381, 1988.

Minayo, M. C. S. Representaçōes da cura no catolicismo popular. In: Alves, P. C. \& Minayo, M. C. S. (Orgs.) Saúde e Doença: um olhar antropológico. Rio de Janeiro: Ed. Fiocruz, 1994.

Sontag, S. A Doença como Metáfora. Rio de Janeiro: Graal, 1984.

Thomaz, W. \& Znarniecki, C. The polish peasant in Europa and America. In: Sociological Research. New York: Harcourt Brace, 1963.

Weber, M. A Ética Protestante e o Espírito do Capitalismo. São Paulo: Perspectiva, 1974. 


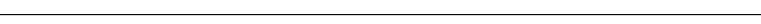




\section{O CONCEITO DE NECESSIDADES DE SAUUDE E AS POLÍTICAS SANITÁRIAS}

Hésio de Albuquerque Cordeiro

No âmbito das representações sociais que envolvem o processo saúdedoença, um problema interessante a ser abordado é pensar de que forma (ou formas) a sociedade se organiza para atender à necessidade de saúde. Essa necessidade traduz-se em três dimensóes, que, embora não sejam obrigatoriamente complementares, representam suas próprias verdades.

A primeira delas refere-se ao fato de a necessidade de saúde, enquanto representação social, não se traduzir da mesma forma em cada classe, fração de classe ou grupo social. Ou seja: o que se pode expressar como necessidade de saúde e se transformar numa ação qualquer para buscar apoio, auxílio, cuidado de saúde não é idêntico entre as pessoas de uma mesma classe e muito menos entre classes distintas. Ademais, essa representação da necessidade repercute na forma como as pessoas se relacionam com os serviços de saúde, públicos ou privados.

A segunda dimensão situa-se do ponto de vista do médico, que expressa a necessidade de saúde de uma forma bastante distinta, estabelecendo-se, assim, um choque entre o saber científico do médico, o saber dominante, e a concepção do indivíduo que recorre ao serviço médico. A fala dessa pessoa que busca o médico para relatar seus sofrimentos, suas mazelas, seus modos de vida não coincide, na maioria dos casos, com aquilo que o médico espera. Tampouco esse relato corresponde a uma definição objetiva de doença. Em geral, é um conjunto de sintomas diferentés daqueles que estão transcritos nos consagrados livros de patologia, de anatomia patológica, de fisiopatologia, em que os profissionais de saúde estudam.

Essa diferença de percep̧̧ōes da necessidade de saúde resulta, muitas vezes, numa relaçăo conflitante. Em alguns casos, o médico recusa-se até mesmo a aceitar que dado problema esteja relacionado à saúde. $E$, na maioria das vezes, ele procura impor sua concepção, sua visão, enquadrando determinado conjunto de sintomas numa categoria de diagnóstico: "Isto é hipertensão arterial, isto é úlcera no estômago." 
Uma terceira dimensāo, a dos planejadores de saúde, dos sanitaristas, dos profissionais de saúde pública, também freqüentemente nāo coincide com as definiçōes do médico. Tampouco coincide com a percepção ou com a definição de necessidade de saúde por parte dos indivíduos que compōem as várias classes sociais.

A definição das chamadas prioridades de saúde, que expressa o modo pelo qual essas necessidades são entendidas pelos planejadores de saúde, usualmente tem uma forma de percepção distinta das outras. Ao dizer: "Não é prioridade nesse momento fazer transplantes renais; vamos destinar mais recursos para combater diarréia infecciosa e desidrataçāo em crianças de zero a um ano", o planejador de saúde está comprando uma briga com os nefrologistas, que afirmam: "Não, a minha especialidade é que é importante. Todos os que tiverem um rim funcionando mal têm o direito de ter esse rim substituído", o que é uma verdade também, até no discurso democrático, da universalização do cuidado da saúde. Já o planejador, com um viés mais tecnocrático, dirá: "Nāo, vamos alocar recursos aqui, formar tais tipos de especialistas, formular tal tipo de programa." Isso freqüentemente difere do que os especialistas médicos dizem e, muitas vezes, não corresponde às necessidades socialmente determinadas e percebidas pela população, entendida não como um todo homogêneo, mas como uma estrutura de classes.

Essa questão aponta para o problema da própria política de saúde. Para precisar melhor este conceito, é importante salientar que política de saúde nāo se resume à política oficial ou institucional de saúde, dos aparelhos de Estado. Existem políticas de saúde formuladas por grupos de interesse, por grupos de pressão, por grupos corporativos. Há, também, aquelas vinculadas a grupos sociais marginalizados, ou excluídos dos sistemas de cuidados de saúde, que se organizam nos movimentos populares para pressionar por reformulaçōes no sistema de saúde. É preciso entender a política de saúde (ou as políticas de saúde) como qualquer política, como um processo de contradiçōes e de relações entre grupos que disputam o poder de forma distinta. Disputam fatias de poder no sentido de impor ou de colocar em marcha seu projeto de saúde ou seu projeto de sociedade.

Nos últimos vinte anos, as políticas de saúde traduziram fundamentalmente um projeto excludente, que não contemplou os movimentos populares, não contemplou reivindicaçōes por outras políticas de saúde e prestigiou, basicamente, um conjunto de articulações, de relaçōes, que se foram dando em torno do Estado para sustentar determinado modelo. Isto se deu, primeiro, estabelecendo-se uma profunda dicotomia entre a saúde pública e a assistência médica, em particular a assistência médica hospitalar. Historicamente, no Brasil, consolidou-se uma forma bastante esquizofrênica de concepção: de um lado, no Ministério da Saúde, um conjunto de instituições foi-se especializando em saúde pública; de outro lado, um segundo conjunto de instituiçōes, vinculadas à Previdência Social, foi-se organizando para dar assistência médica e hospitalar, separando não só as formas de per- 
ceber e de representar a doença, mas também as formas de intervenção do Estado no sentido de promover umas ou outras.

Em conseqüência dessa separação, a saúde pública, historicamente, foi perdendo prestígio e recursos, tendo seus orçamentos reduzidos de tal forma que, entre 1969 e 1970, o do Ministério da Saúde representava apenas 0,9\% do orçamento global da União, enquanto, na década de 50 , girava em torno de 3 a $4 \%$. Embora a saúde pública nunca tenha tido muito prestígio, constata-se que a situação se agravou mais ainda a partir da década de 70 , quando se reduziram os projetos de saúde pública e se hipertrofiaram os projetos de organizaçāo da assistência médica e hospitalar.

Esse movimento partiu de um mecanismo de concentração de poder e de recursos econômicos na Previdência Social, no então INPS, criado em 1967. Dez anos depois, deu-se o segundo momento de maior concentração, com a criação do Inamps e uma reestruturação de todo o sistema da Previdência Social, orientado por uma visão e por uma política de expansão do atendimento hospitalar, atendimento esse constituído fundamentalmente pela área hospitalar privada. Ademais, o movimento direcionou a ampliação do mercado de consumo de medicamentos e de equipamentos médicos a partir da ação do Estado via Previdência Social, estabelecendo o que se vem constituindo como o complexo médico-industrial. Essa estruturação proporcionou uma forma de organização intensamente privada da prestaçăo da assistência médica, articulada com as indústrias farmacêutica e de equipamentos e, mais recentemente, com o seguro-saúde, uma espécie de presença do capital financeiro 'organizando' o setor saúde privado, intrometendo-se no setor público e esvaziando o projeto de organizaçāo pública do sistema de saúde.

A partir do processo iniciado em 1966 - e considerando que estamos hoje enfrentando um processo contraditório e transitório de reordenação desse sistema de saúde -, estabeleceu-se, em termos de políticas oficiais de saúde, uma separação crescente entre 'saúde pública' e 'medicina curativa', com um esvaziamento institucional da chamada saúde pública e uma privatização acelerada e intensa dos recursos da Previdência Social. Privatização não só dos recursos dos trabalhadores, mas também dos consumidores, pois hoje todas as pessoas que adquirem qualquer bem estão contribuindo indiretamente para a Previdência Social, já que a parcela do empregador se transfere ao preço da mercadoria consumida. Esse tipo de concepção certamente contribui para fragmentar a própria concepção de saúde e doença.

Essa dicotomia foi representada por uma fragmentaçâo extremamente acentuada das políticas sociais no campo da saúde. Não é exagero dizer que essas políticas não só segmentaram a saúde pública, como também a medicina curativa, separando as doenças por nível de competência: doenças federais, doenças estaduais e doenças municipais. "Malária é da esfera federal, é com a Sucam, mas tratar criança já se tornou uma tradição das Secretarias Municipais." Essa segmentação traduz uma forma também bastante desintegrada de cuidar do fenômeno vida, 
porque se lida com o vetor, com o vírus ou com o sistema, de modo que a relação entre a populaçāo e o senviço de saúde se apresenta de forma totalmente rompida.

O que ocorreu de grave no Brasil foi um processo intenso de privatização, ao se restringir o âmbito do processo de saúde e doença ao restabelecimento ou à restituição - da força de trabalho, e, principalmente, ao se criar um sentido da lucratividade do trabalho de prestação de cuidados de saúde. Assim, além de ser uma forma de restabelecer a capacidade de trabalho do individuo, também se tornou objeto de lucro, objeto de um processo específico de transformaçāo e de crescimento, de acumulação capitalista, consubstanciado e estruturado na forma das empresas médicas.

São, portanto, dois processos simultâneos, o que leva ao entendimento de: que, na própria organização do sistema de saúde, não há uma única representação da doença. Assim é que o empresário da saúde - ou aquele que vende a apólice do seguro-saúde -, o sanitarista e o médico liberal - que atende no consultório do subúrbio - vão expressar concepçōes bem distintas em relação ao processo saúde e doença. Isso tem gerado e ampliado um sistema de desigualdades.

Mesmo admitindo que a questão das relaçōes entre a população c cs serviços já esteja mais ou menos equacionada, temos que pensar que existem outras formas de desigualdade, e uma delas refere-se ao acesso ao serviço. A situação da população da área rural do País é ainda extremamente precária, correspondendo, em média, a menos de uma consulta/ano por habitante. A área urbana - onde se situam dois terços da população - está na faixa de duas consultas/ano por habitante. É evidente que essa média reflete muito mal também as desigualdades, pois certamente alguns segmentos dessa população urbana, das classes médias para cima, têm mais facilidade de acesso, têm mais consultas, vâis ao médico mais ou menos quando querem. Ainda que a população urbana das favelas freqüentemente busque a atenção médica, constata-se que, ainda assim, na média, esse acesso é muito precário. Na Baixada Fluminense, há um déficit de quase três milhões de consultas/ano.

Há, portanto, um diferencial de acesso das pessoas aos serviços, desigualdade essa que se expressa em função das classes, bem como das regiões do País, já que o número de consultas por habitante no Nordeste é menor do que no Sul e Sudeste. Há um acesso diferencial em relação à qualidade do cuidado de saúde, não só em termos da atenção e da forma como se estabelecem as relações médicopaciente, como até, por exemplo, no tempo gasto na consulta com pacientes de classes sociais distintas.

Analisando o conteúdo dessa relação, observa-se que o médico, ao se relacionar com uma pessoa empiricamente classificada como 'classe média alta', não é tão impositivo, é mais atencioso, dá muito mais explicaçōes, procurando usar uma linguagem que se aproxime do universo conceitual daquele paciente. Quando se relaciona com um trabalhador ou com um paciente das chamadas classes populares, o 
tempo de consulta é menor, e o conteúdo da consulta é muito prescritivo: "Você vai tomar esse remédio porque vai the fazer bem". Não interessa muito explicar o mecanismo da doença e o mecanismo de atuação daquele medicamento. É uma relação muito mais assimétrica do que aquela com um paciente das classes dominantes.

Há ainda um diferencial de gastos em saúde. Embora, no Brasil, o gasto público em saúde não chegue a cinqüenta dólares por habitantes/ano, ele está mais concentrado nas regióes Sul e Sudeste, exatamente porque foi muito direcionado para o atendimento hospitalar de natureza privada.

Esse contexto é acrescido de um conjunto de desigualdades das próprias formas de adoecer e de morrer. Desigualdades que se traduzem com maior gravidade, com maior freqüência, num maior grau de sofrimento para as classes dominadas, para os segmentos mais pobres das classes trabalhadoras. Costumase dizer: "Pressão alta, infarto, câncer, isso é doença de rico." Pobre morre de diarréia, de desidratação, de infecção respiratória aguda; morre de câncer de pulmăo, de câncer de mama, de câncer de colo uterino, de câncer de estômago; morre por homicídio, de acidentes, de várias formas de violência. Morre, inclusive - mais do que o rico - de infarto, derrame, acidente vascular cerebral, lesão nos rins, hipertensáo. Isto significa que nas camadas mais pobres não só se concentram as doenças, como também se revestem de maior gravidade aquelas popularmente identificadas como 'doenças de rico'.

Esse conjunto de desigualdades reflete políticas oficiais, públicas, que na realidade tiveram muito pouco de públicas, já que visaram primordialmente ao fortalecimento de um setor médico empresarial, cuja forma de funcionamento e dinâmica de crescimento reforçaram uma concepção baseada no lucro. Uma concepção, portanto, de reprodução e ampliação das desigualdades sociais, que contribuiu para excluir segmentos importantes da população brasileira do acesso aos serviços de saúde.

Todo o movimento de denúncia e de luta contra o crescimento desse complexo médico-empresarial, assim como a própria politização do conceito de saúde e doença, ampliando-se o sentido do processo saúde e doença, é que caracteriza o conceito ou o movimento da Reforma Sanitária. Ou seja, o entendimento de que é preciso ter um conjunto de políticas sociais articuladas, integradas, para mudar concepçōes de modos de vida, de alguma forma ligadas à gênese de uma dada situação de saúde e doença da populaçāo.

Esses problemas têm que ser encarados de forma articulada e integrada por meio de políticas que enfrentem os agravos ligados ao meio ambiente, à falta de saneamento, à questão do salário, às condições do ambiente de trabalho, aos riscos que se traduzem no processo de trabalho e à própria qualidade dos serviços de saúde. Mais ainda: seria preciso aproximar essas duas concepçōes de saúde pública e de medicina curativa que se divorciaram, promovendo o que os sanitaristas e os planejadores de saúde passaram a chamar de "integralidade das açōes de saúde". isto significa entender que não adianta assistência médica se não houver também 
melhores condições de nutriçāo, de saneamento, enfim, melhores condições de vida. É preciso que essas açōes sejam conjuntas e, mais ainda, que isso se traduza num direito de toda a populaçăo. Implica, portanto, a universalização do acesso ao serviço de saúde, rompendo com uma outra concepção, a do seguro-saúde.

Quando se organizaram os institutos de aposentadoria e pensão como uma forma de seguro social para a classe operária e vários outros segmentos de trabalhadores do País, no sentido de dar maior garantia em situaçōes de perda de emprego, de doença, isso representou um avanço nos trinta primeiros anos deste século. Representou absorver conquistas extraordinárias das lutas da classe operária européia dos séculos dezoito e dezenove, mas que, numa visăo atual, representam uma concepção restrita do direito social.

A idéia do seguro social é a de que o trabalhador deve contribuir com uma parcela do seu salário para que, na aposentadoria, na doença, na invalidez, tenha condiçôes de se manter. Essa concepção do seguro, contudo, exclui setores que não estão na força de trabalho. Se a pessoa estiver desempregada ou se trabalhar no setor informal da economia, não contribui para nenhuma forma de Previdência Social e, portanto, também nāo tem qualquer direito. Essa concepção do seguro social está sendo rompida segundo o conceito de universalização, que é a forma mais abrangente, é a forma da Seguridade Social entendida como algo que coincide com a universalização do acesso. De acordo com esse conceito, năo é preciso ser trabalhador inserido no mercado formal de trabalho para obter atendimento médico, para ter inclusive certos direitos sociais, certos benefícios, como seguro-desemprego. $\mathrm{O}$ idoso sem nenhuma forma de subsistência tem garantido, pela Constituição, o direito de receber pelo menos um salário mínimo para sua manutenção.

Situo todo esse processo e essa formulaçāo das políticas de saúde na atualidade dentro desse marco da universalização, do reconhecimento do direito à saúde e do direito social, do direito numa concepção mais ampla do que a do seguro, que é o da Seguridade Social, dentro de um princípio de integralidade, isto é, o de colocar juntas, do ponto de vista de conteúdos das açōes de saúde, as partes tanto preventiva quanto curativa.

A aprovaçāo de uma lei complementar à Constituição vai reordenar o Sistema de Saúde no Brasil, unificando as partes preventiva e curativa via Ministério da Saúde, para, institucionalmente, se traduzir em integralidade das ações. Esse conjunto de propostas é ainda uma espécie de ideário de lutas. Pela história dos sistemas de saúcle do Brasil, pode-se entender por que razōes surgiram, surgem e surgirāo oposições a essas propostas. $O$ setor privado encara com muito temor o fortalecimento e a reordenação do setor público, fazendo uma ofensiva bastante intensa pelos meios de comunicação, no sentido de buscar uma alternativa, fora do Estado, para o financiamento da área privada com a poupança das pessoas que podem pagar seguro-saúde. Atua, assim, de forma até bastante inteligente com a crise, com as dificuldades de fortalecimento do setor público e com o que este signi- 
fica em termos de formulação de alternativas para a melhoria do acesso e da qualidade. Jogando com essas dificuldades, o setor privado oferece alternativas do tipo: "Esse negócio de posto de saúde fica para os pobres; vocês, da classe média, que vêem televisão colorida, têm uma alternativa melhor, uma forma de buscar e escolher o seu médico, por meio do seguro-saúde". Propõe-se, assim, uma nova forma de diferenciação de classes no acesso ao serviço de saúde.

Nessa discussão, um desafio importante na defesa do serviço público de saúde consiste em explicitar que não basta ser público, é preciso que seja democratizado no sentido do acesso, do controle social, da fiscalização e, mais ainda, que ele funcione no sentido da qualidade do atendimento, recebendo recursos que permitam efetivamente tornar disponivel o que há de moderno para o conjunto da população. A percepção hoje é de que o serviço público, nessa competição de mercado de consumo de saúde, deve oferecer serviços que contemplem também a classe média, a classe dominante, no sentido de fortalecer a concepção de um serviço público de saúde. O desafio que se enfrenta é o de ampliar realmente o acesso para cerca de quarenta milhóes de pessoas que hoje estão praticamente à margem do sistema oficial de saúde. São pessoas que têm estratégias próprias de sobrevivência, que buscam soluçóes alternativas para seus problemas de saúde em outros sistemas, como os vinculados às religiōes ou as práticas populares, como forma de resolver o problema do sofrimento que decorre da doença. 



\section{DEBATE}

Considerando as diferentes concepçöes de saúde e políticas públicas, que tipo de formação seria mais adequado e que necessidades deveriam estar contempladas na formação de pessoal de nível médio (técnico) da área de saúde? Além disso, a dicotomia saúde pública e assistência médica não seria uma divisão necessária, por constituirem duas áreas de competências distintas, que não se confundem e nem se fundem? Controle das doenças, do meio ambiente, implica políticas distintas da atuação médica. Ademais, será que o Estado tem que oferecer serviços para toda a população, seja serviço médico ou educação? Ou será que o Estado, hoje, não é o equivalente ao asilo que já existia na ldade Média para atender a quem fosse morrer? Como defender a saúde ou o ensino público e gratuito, dadas as condiçōes em que esses serviços são oferecidos?

\section{Hésio Cordeiro}

Não se trata de defender o serviço público na forma em que ele se encontra. Entre os países capitalistas de industrialização tardia, o grau de desigualdade social é dos mais profundos em termos de acesso aos serviços ou de salários. Imaginar que, no Brasil, oitenta milhões de pessoas recebem menos de cinco salários mínimos e que, desse contingente, quarenta milhöes vivem abaixo da linha da pobreza absoluta, recebendo menos de um salário, é se aperceber do grau de precariedade da situação não só de saúde, mas de vida dessas pessoas. Acredito que a conquista de novos instrumentos se dê por meio da política pública - não a do Estado excludente, não a do Estado autoritário, mas a do Estado democrático. A ação da política pública da área econômica e social firma-se como condição necessária para promover uma redução dessas desigualdades sociais. Para isso ocorrer com eficácia, tem-se que promover mudanças na área do deteriorado ensino público, bem como 
na área de saúde, já que as modificações institucionais da saúde ainda não atingiram a 'ponta da linha' para atender melhor à população. É preciso defender uma concepção de política distinta da que vem sendo proposta no Brasil em todo debate sobre a ação do Estado.

Hoje, está em voga - e é um assunto debatido tanto pela esquerda, quanto pelos setores mais conservadores e liberais - a idéia de que o Estado cresceu demais, que as instituiçōes do Estado são ineficientes, que o serviço público é péssimo, que o funcionário público não trabalha e, portanto, que a qualidade do servidor é inferior. É preciso recuperar e recolocar a concepção de Estado e a concepção de política pública. De que forma? Todos os argumentos sempre levam à seguinte conclusão: como o Estado não funciona, como os serviços são ruins, resta fortalecer o privado, o filantrópico, enfim, fortalecer a sociedade fora do Estado, como se isso fosse o suficiente para promover uma redução das desigualdades sociais. Isso é o que o chamado pensamento neoliberal está propondo, as várias vertentes neoliberais discutem esta questão: "Se o Estado cresceu muito e não funciona, vamos reduzi-lo. Existe a questão dos 'marajás' do funcionalismo público, o inchaço da burocracia do Estado, desse modo não adianta pagar melhor aos professores nem aos profissionais de saúde, pois qualquer ação estatal é fadada ao insucesso". Às vezes, encontramos o mesmo discurso em alguns pensadores da esquerda (ou das esquerdas), no sentido de fortalecer mais a sociedade civil, porém diminuindo o âmbito das políticas públicas. Imagino que só se pode defender o serviço público por meio de uma formulação distinta da própria concepção da relação do Estado com as classes sociais e da restituição da dignidade do serviço público. Isso só pode ser conseguido por meio de um debate ideológico profundo, em que se definam prioridades e, fundamentalmente, por meio de recursos orçamentários que considerem essas prioridades.

É impossível resolver a questão da qualidade do serviço público sem definir uma política econômica ou uma política social que solucione alguns estrangulamentos em relação tanto à dívida externa quanto à estrutura do gasto público, numa perspectiva de combate à recessăo e à posição ideológica, na esfera social, de que o Estado precisa gastar menos, e, na área econômica, à ideologia da privatização das empresas estatais. Nesse campo, aliás, alguns mais moderados e conscienciosos chegam a afirmar: "Vamos privatizar somente as ineficientes, as deficitárias, mas vamos preservar, por exemplo, a Petrobrás". Outros são mais audaciosos: "Vamos privatizar inclusive a Petrobrás, porque assim haverá concorrência e ela se tornará mais eficiente".

Esse enfoque 'anti-Estado' das chamadas posiçóes neoliberais tem que ser combatido, em função de uma nova concepção, de uma nova democratização do Estado, de uma ampliação dos canais de participação em relação às políticas públicas e de uma valorização do senviço público. Na questão da saúde pública e da medicina curativa, há saberes distintos envolvidos. O metabolismo do fígado, por exemplo, envolve um saber médico bem localizado, distinto do saber que trata dos 
vetores ou dos riscos ambientais. Mas o problema está menos nesses saberes e mais na organização da ação estatal, na destinação de recursos para o desenvolvimento das açóes. Ou seja: na hora de alocar recursos ou de definir prioridades para tal ou qual área, é melhor que isto se dê numa única instituiçăo e nāo em instituiçōes que disputam o poder entre si.

O orçamento do Inamps é da ordem de quatro bilhões de dólares, o do Ministério da Saúde é dez vezes menor. O Ministério da Saúde pode propor tal ou qual prioridade, mas, se essa prioridade nāo se traduzir em recursos, de nada adiantará. Com o outro conjunto de decisões situado na esfera da medicina curativa, privilegiava-se outro tipo de ação, a hospitalar. É lógico que não suponho que basta juntar os dois orçamentos e repartir o dinheiro para que tudo se resolva, mesmo porque se gasta mal e pouco em saúde. Também não se conseguirá ampliar o gasto em saúde em curtíssimo prazo (hoje, o Brasil gasta em torno de $5 \%$ do Produto interno Bruto em saúde, 2,5\% público e $2,5 \%$ privado).

Algumas estimativas apontam que, só para recuperar os serviços públicos de saúde - considerando aumento de salários, isonomia, tempo integral, recuperação física da rede, que se deteriorou nos últimos anos -, seria necessário aumentar os recursos de $2,5 \%$ para $5 \%$. Parece pouco, mas, quando se imagina tal percentual dentro do volume do que representa o Produto Interno Bruto brasileiro, os números crescem muito. Competem com os números da dívida externa e com os do pagamento dos juros.

Não é, portanto, uma questão de efetuar pequenas modificaçōes aqui ou ali. Isso implica não só muito dinheiro, mas também a formulaçāo de uma política econômica e social integrada. De qualquer modo, a idéia da unificação garante, pelo menos, que as prioridades se expressem com mais nitidez. Vamos resolver o problema da malária em Rondônia por açôes dirigidas ao meio ambiente, ao tratamento dos doentes, ao combate aos vetores. Isso tem que se traduzir em um volume de recursos e em sua aplicação correta, pois também não adianta fornecer os recursos e desviá-los para outra finalidade.

\section{Cecília Minayo}

Muitas contradiçōes permanecerão no processo da chamada Reforma Sanitária, que vai mudando de atores e autores. Muitos dos que pensaram a Reforma já não estão mais atuando na sua implantação. Sonho com o dia em que qualquer bairro popular tenha seu centro de saúde ou seu hospital, sua unidade primária ou secundária, onde as pessoas possam ter atendimento gratuito às suas necessidades médicas. A isso eu chamo serviço público. Quando penso no que é possivel realizar para que a população tenha o seu serviço de saúde, sem enfrentar filas, com um tratamento digno, com saneamento básico, não tenho a menor dúvida 
de que isso é dever do Estado, mesmo porque nós contribuímos por meio dos impostos para ter esses direitos assegurados. O desafio é conseguir institucionalizar um ideal agindo contra a maré da desvalorização e do desrespeito à população, pois, freqüentemente, a ação passa a se dar desvinculada, descolada do idealizado, desvirtuando-se totalmente a idéia de público e da Reforma Sanitária.

A contradição que a Reforma Sanitária enfrenta conta, de um lado, com a pequena participação dos movimentos populares, dos sindicatos, e, de outro, coincide com a própria crise, real ou fictícia, que o Estado brasileiro atravessa. Há dados econômicos positivos em relação ao crescimento do PIB e ao crescimento da exportação, mas isso não se vem refletindo em melhoria da qualidade de vida. Em 1970, por exemplo, o peso da massa salarial no PIB representava $38 \%$, e agora significa $30 \%$.

Então, há uma crise real e uma crise criada pela classe dominante. As contradiçōes estão passando pelo econômico, pelo político e têm repercussão concreta na possibilidade de implantação de um sistema universal.

Quanto à formaçăo dos que trabalham com saúde, deve-se ter como princípio norteador que eles vão tratar com seres humanos. Do ponto de vista filosófico, isso significa colocar esta concepção no 'coraçāo' de qualquer currículo. Para isso, não basta incluir Antropologia e Sociologia como disciplinas optativas nos currículos do médico e do pessoal técnico. Trata-se de fundamentar a 'ação técnica' por uma ideologia claramente 'humanística'.

A questāo técnica é muita séria, mas, do meu ponto de vista, o técnico que não for totalmente envolvido pelo humano será um técnico de robô, não um técnico de gente. Penso dessa maneira em relação à formação de todo o pessoal que trabalha com a saúde.

A visão popular da saúde e da doença parece central. Contudo, considero não ter sido abordada, com a ênfase devida, a questão do sobrenatural, do porquê da doença $\varepsilon$ como se materializa a justificativa do sobrenatural na visão popular, no sentido de dar uma resposta àquilo que o individuo desconhece. Resposta que, por um lado, talvez represente uma forma de acomodação, mas que também pode significar, para o indivíduo, a perspectiva de mudança de que ele necessita. Parece-me que a questão educacional está muito próxima dessa visão popular do porquê da doença e da saúde. Ela é uma visão mais totalizante do que a da classe dominante, que é positivista, fragmentária, porque assim the interessa.

Desse modo, o processo educativo deveria deixar de se restringir ao ensino, à educação strirto sensu, e abranger até as lideranças sindicais, que são fundamentalmente corporativistas e que, no mais das vezes, têm uma visão fetichizada de que as 
ciências, sejam da natureza ou sociais, constituem, em si, a verdade. Não seria essa a resposta para compreender o ensino como processo, para construir uma visão de saúde totalizante, integral, resgatando o que há de totalizante e de integral na visão popular, tentando descartar o elemento mítico, que não responde efetivamente? Como resgatar a própria condição de agente revolucionário, de agente de transformação social, na medida em que o sobrenatural tem esse lado material, mas é utilizado pelas forças dominantes como uma força de acomodação?

Costaria ainda de abordar um segundo tópico: o da Reforma Sanitária. Jaime Oliveira, em um de seus trabalhos, compara as reformas da saúde italiana e brasileira, que são distintas principalmente pelo fato de que a italiana vem 'de baixo para cima', e a brasileira caminha no sentido inverso. Além disso, a italiana tinha uma perspectiva que não findava na própria reforma da saúde, e, sim, na superação do modo de produção capitalista, mediante a ocupação de posições, quebra do Estado, implantação do socialismo. No Brasil, segundo esse autor, o que existe ainda é um modelo um tanto ou quanto 'social-democrata', por questões conjunturais. Ele atribui o peso dos equivocos principalmente aos partidos politicos, aos quais caberia tentar trabalhar essa visão da transição, da guerra de posiçōes, de a Reforma Sanitária representar um processo de luta maior, mais ampla.

\section{Cecília Minayo}

Os núcleos de bom senso que existem no pensamento popular são altamente aproveitáveis do ponto de vista tanto da educação enquanto interferência, como da educação enquanto inter-relação. Coordenei uma pesquisa em seis favelas da Penha, não só na parte de entrevistas individuais e visitas domiciliares, mas também promovendo reuniões para discutir saúde. Constatei que as pessoas têm essa concepção ampliada de saúde e que sabem expressar muito bem as prioridades que thes interessam em relação a esse tema. Participei de reuniōes em que as pessoas afirmavam com clareza: "Na nossa favela, neste momento, a gente precisa é de contenção de encosta". Outro depoimento revelador foi o de uma senhora que buscou o hospital, e o médico lhe disse: "Isso aqui é uma gangrena, tem que cortar a perna". Ela fugiu, e todos a apoiaram: "Você não vai cortar a perna, nós vamos cuidar". Então, contando com a médica do centro de saúde e fazendo uma série de tratamentos alternativos, a senhora foi-se recuperando. Houve, assim, um real enfrentamento.

Em relação a esse tema, penso que o conceito de salário em Marx pode contribuir para o debate Para ele, o salário tem duas funçôes: cobrir a necessidade de subsistência e atender às necessidades sociais. Em cada época, há um nível de vida que não é mais dado somente pelas necessidades básicas. A partir daí, todos temos direito e devemos brigar, porque há o direito, mas não o acesso. A população de 
favela - estou falando de favela no Rio de Janeiro - tem a compreensão de que precisa lutar pelo acesso ao hospital, mas também pelo saneamento, pois o que está prejudicando sua vida sāo os ratos, as valas negras e a falta de água encanada e potável. Em outros casos, a população tem que partir para uma luta ecológica, porque determinada fábrica está causando um nível de poluição prejudicial à vida dela. No caso da Penha, o movimento popular assumiu essa reivindicaçăo.

Junto a essas questōes, surge também a do sobrenatural, mas que aparece de uma forma que nāo é só mágica, e é isso que às vezes confunde, como se a mágica substituísse a ciência. Não é bem assim. Os núcleos de bom senso existem não só no pensamento popular, mas no de todos nós e, por isso, nos tornam passíveis de mudança e transformação. E é esse limite que nos ajuda a pensar a educaçăo no sentido político de mudança. Em várias discussões com a populaçāo, pude observar recorrentemente a frase "foi Deus quem me curou", seguida de "pelas mãos de dona fulana (curandeira)". Mas essa reverência a Deus nunca ocultou a crítica aos serviços e profissionais considerados omissos ou às condiçōes de vida e trabalho geradoras de doença.

\section{Hésio Cordeiro}

É difícil comparar os processos das reformas italiana e brasileira. Em primeiro lugar, o processo brasileiro ocorreu num contexto absolutamente dife-rente, de transiçāo democrática, de passagem de um regime autoritário, ditatorial, para um mínimo de conquistas democráticas. A mobilização em torno da saúde não tinha o sentido da passagem do capitalismo ao socialismo, mas sim da passagem da ditadura para algum grau de regime democrático dentro da própria ordem capitalista. É lógico que a questão não estava colocada só nesses termos. Existem vários projetos de Reforma Sanitária, da mesma forma que existem vários projetos de socialismo. Provavelmente, o projeto socialista do PT não é exatamente o projeto socialista do PCB ou do PC do B. Há, também, vários socialismos em questão, e um aspecto em que se avançou nesse debate é o de que, na maioria das vezes, na arena do debate político, ninguém tem absoluta segurança de que sua verdade seja a única. Isso foi algo importante a que os movimentos socialistas conseguiram chegar.

No projeto da Reforma Sanitária brasileira, várias estratégias foram colocadas em marcha, umas com uma visāo mais transformadora do modo de produção e outras mais de consolidação democrática. No campo específico da saúde, há dificuldades e enfrentamentos extremamente localizados, mas importantes, dentro do processo de reordenação do sistema de saúde e no interior da própria organizaçāo de um dos seus componentes, os serviços. Não sei se vêm de cima para baixo ou de fora para dentro, mas houve e há um movimento crescente não só dos sanitaristas, mas também de movimentos populares, e uma crescente ampliaçāo da consciência 
sanitária em relação não apenas aos determinantes da saúde e doença, mas também ao direito à saúde, à necessidade de fortalecer outro tipo de serviço público de saúde que nos dê mais qualidade, mais acesso etc.

Pode ser que os processos de decisão tenham sido menos participativos, mas não podemos negar que, nos últimos dez anos, a chamada consciência sanitária se ampliou muito no País, especialmente por meio dos movimentos populares, dos movimentos sindicais. Um setor importante de resistência à unificação do sistema de saúde era a área sindical, que tinha a sua concepção do seguro social. Argumentava-se: "Quando houver a unificação, vou perder o direito de ser atendido no hospital de Ipanema, que é do INPS". Nas décadas de 40 e 50 , houve enorme resistência à Lei Orgânica da Previdência Social, que unificaria todos os benefícios, pois os bancários não queriam se igualar aos comerciários. Naquele momento, a chamada solidariedade da classe operária, ou da classe trabalhadora, desapareceu. Era o bancário disputando com o comerciário e o rodoviário urbano, que tinha menor salário e era mais doente, e o laptec possuía um precário hospital em Bonsucesso. Isso é para assinalar que o movimento social de superação de uma série de entraves à Reforma Sanitária ocorreu simultaneamente ao desenvolvimento do próprio processo da Reforma.

A construçāo e a superação das várias ideologias em choque foram, estão sendo e serão um movimento de luta política muito intensa. Atualmente, o processo italiano enfrenta dificuldades enormes, com o movimento médico corporativo se opondo à reforma. Isso sem mencionar que a aprovação da legislação da Reforma Sanitária italiana ocorreu mediante uma grande coalizăo entre os partidos Socialista, Comunista e o Democrata Cristão. Do ponto de vista da legitimação do processo político por meio da ordenação legal, isto é, como se constituem distritos sanitários, como se organiza o sistema, como se fortalece o poder local, tudo isso ocorreu a partir de um acordo político entre os três grandes partidos e as três grandes centrais sindicais a eles vinculadas.

Atualmente, vem ocorrendo um certo desmoronamento da reforma italiana em função da esperada ruptura da coalizão entre o Partido Comunista, de um lado, e os partidos Socialista e Democrata Cristão, de outro. Também contribui para isso a resistência corporativa da categoria médica, que é extremamente forte. Contudo, a reforma avançou em outras dimensões, que ainda não alcançamos, como, por exemplo, na área da saúde do trabalhador e da presença dos sindicatos na fiscalização e controle do ambiente de trabalho. Os centros comunitários, as unidades médico-sanitárias possuem especialistas que medem a exposição aos agentes químicos, físicos e biológicos. Ao lado disso, técnicos do movimento sindical fazem as medições para conferir os dados fornecidos pela fábrica e pelo serviço de saúde.

Analisando retrospectivamente $o$ processo da reforma italiana - processo mais demorado que o nosso, porém igualmente difícil -, penso que ele está longe de 
apontar para o socialismo. É lógico que inclui, na intençāo das forças sociais e partidárias, algumas propostas de cunho socialista e outras simplesmente reformistas no sentido da social-democracia. Nós, entretanto, estamos aquém disso. O contexto da nossa Reforma Sanitária foi absolutamente distinto, pois o que estava em jogo era a ampliação dos espaços democráticos mais do que qualquer outra transformação social mais profunda.

Determinada concepção de saúde é construída nas relações sociais dadas pela sociedade, mas é também certo que o sistema de ensino, o sistema de formação profissional, tem um papel importante, mas não determinante, na modificação dessa concepção. Assim, pensar em reformulação ou em movimento contra-hegemônico é pensar a formação desses profissionais.

A questão da educação para a saúde, educação na saúde ou educação em saúde, na verdade, é apresentada de forma superposta, sem que se apresente uma efetiva articulação entre os dois sistemas (saúde e educação). Identifico isso, por exemplo, quando se discute a Reforma Sanitária. Penso que não se implementa essa proposta sem passar pelos profissionais que, em última instância, respondem por sua execuçāo. Quando afirmo que nāo existe essa articulaçāo, mas uma justaposição, é que, da leitura dos documentos da Conferência Nacional de Saúde, pode-se deduzir, por exemplo, que o movimento de saúde tende a querer resolver o problema da formação profissional em si e por si, sem buscar articulaçāo com o sistema oficial de ensino. Penso que isso apresenta sérios óbices, pois existem papéis que não competem à área de saúde, já que ela não tem como dar conta de forma satisfatória do problema, restringindo-se aos cursos emergenciais. Claro que existe um contexto que exige determinada intervenção imediata ou mais direta. Mas é papel desse movimento refletir sobre essa articulação entre os sistemas da educação e da saúde, bem como sobre o tipo de profissional para a construção do projeto de Reforma Sanitária. Ainda hoje, está muito presente a concepção do profissional enquanto mais um dos recursos que sustentam o Sistema de Saúde, com propostas de formação visando à eficiência desse recurso, à efetividade do papel desse profissional. Portanto, do ponto de vista da Reforma Sanitária, como é encarada a formação dos profissionais da saúde e a articulação entre os setores educação e saúde? 


\section{Hésio Cordeiro}

Uma das grandes carências da Reforma Sanitária está na área de formação da força de trabalho em saúde. Entender a Reforma Sanitária como algo global, e não apenas como a simples reestruturação de serviços de saúde, apresenta como um grande desafio esse campo de recursos humanos ou de pessoal de saúde.

Em toda crítica à política de saúde do regime autoritário, afirmava-se que a educação dos profissionais de saúde só se modificaria quando, de certa forma, dependesse das condiçōes de organização do mercado de trabalho em saúde. Nas reuniões da Associaçăo Brasileira de Educação Médica, repetia-se isso exaustivamente. Ao se procurar delinear o perfil do médico de que o País necessitava, a definição era dada pela forma de inserção no mercado de trabalho, pelo processo de privatização, pelo crescimento da prática hospitalar especializada. Aplicava-se também o mesmo raciocínio aos demais profissionais de saúde dentro de um processo de divisão social e técnica do trabalho em saúde, desqualificando certos segmentos desse pessoal e qualificando ou superqualificando outros.

No âmbito da Reforma Sanitária, excetuando-se determinadas palavras de ordem muito gerais, como, por exemplo, a necessidade de desenvolver experiências no sentido de integrar ensino e serviço, penso que não se conseguiu ainda formular com clareza a proposta de formação do profissional de saúde. É uma área precária, um dos pontos mais graves de estrangulamento. Seria preciso equacionar o conteúdo de conhecimentos técnicos que esse pessoal deve ter com o que se entende por conhecimentos humanísticos, que, aliás, prefiro chamar de compromisso social com a saúde. Um aspecto importante, no caso dos médicos, é o crescente descompromisso para com o doente. Salvo exceções, atender a uma pessoa com uma queixa significa resolver o problema o mais rápido possivel, de preferência passando adiante, para outro especialista. Aquele indivíduo não tem nome nem sobrenome, no máximo sofre de pressão alta ou possui uma úlcera que dói, mas o que vai acontecer depois ou o que aconteceu antes não está na esfera das preocupaçōes do médico. A preocupação é com o cuidado imediato, o cuidado tópico.

Imagino uma reorganização do sistema de saúde no sentido de mudar o conteúdo das práticas de saúde. A idéia do distrito sanitário, que tanto se discute, passa menos pelo planejamento e organização administrativa do que pela concepção de um novo conteúdo dessas práticas, em que a equipe de profissionais, de modo coletivo, se organize para que, no processo de trabalho, os doentes năo sejam objetos, mas sujeitos que interagem, que têm uma história, uma vida, năo se traduzindo apenas em indicadores de saúde.

A formação do pessoal de saúde deveria ser discutida a partir de situações concretas de trabalho em distritos sanitários, dentro da concepção da mudança do conteúdo das práticas, questionando-se esses profissionais na sua própria prática. Por exemplo, o radiologista não está ali somente para fazer ou interpretar uma ra- 
diografia de pulmão. Ele tem que inscrever sua atividade dentro de um processo de trabalho que vai resultar em algum benefício para aquela pessoa que sofre e que foi fazer a radiografia. Isso significa tentar - reconhecendo que o parcelamento desse processo de trabalho é inevitável, tanto pelo próprio avanço tecnológico, quanto pela forma de organização social da prática de saúde - uma recomposição desse processo sob um outro compromisso social, na ótica de um conjunto de trabalhadores de saúde que prestam determinado tipo de atendimento. Como isso se traduz em currículos, em planos de estudos, em técnicas educacionais é um campo em que não se avançou nem na esfera teórica nem na política.

\section{Cecilia Minayo}

Realmente, năo se avançou muito nessa área, e isso não é ingênuo, não é neutro. A formação médica está marcada pelos interesses de um grupo hegemônico, voltados principalmente para a especialidade, a produtividade, a incorporaçăo de novos equipamentos e tecnologias. O doente é um ser fragmentado no pensamento médico dominante. Assim, quando se pensa um currículo, está-se pensando nessa fragmentação.

Tome-se como exemplo o pessoal de residência médica em Pediatria que está acabando a graduação e começando a praticar. A maioria desconhece completamente os problemas da criança. Por quê? Porque o interesse nâo é saber sobre a criança, mas sobre a doença. Isso não é ingênuo, porque hoje se especializa para a doença. A educação, de certa forma, é caudatária.

A Reforma Sanitária é uma questão mais ampla e, ainda que tenha reformulaçōes curriculares como um de seus componentes, tem que ser pensada e compreendida não como alguma coisa voluntarista, mas como luta política, luta econômica e também como uma tarefa educativa e um projeto cultural. Caso contrário, se esvai no fracasso administrativo. Será que um dia a pessoa - doente ou sã - terá vez? Parece estranha a pergunta, mas constato que o doente é o que menos vem importando nessa discussão. Na verdade, o interesse está voltado para a doença, a especialização, o ganho pecuniário, a localizaçāo do consultório particular. Apenas em alguns centros, como a Escola Nacional de Saúde Pública, onde as pessoas fazem especialização, mestrado, doutorado, é que se discutem mais globalmente esses problemas, uma vez que lá a preocupação primeira não é com a formação médica.

Sobre a questão da hegemonia, constata-se que ela não diz respeito apenas ao pensamento biomédico localizado, mas inclui os profissionais que integram uma equipe de saúde. Na medida em que se define que saúde é o oposto de doença e que quem cuida da doença é o médico, de certa forma se hegemoniza um sujeito ao qual todos são submissos. É possível que outro grupo pense e se posicione de modo diferente, mas certamente será exceçāo. 
Uma outra questão é, na verdade, uma crítica à Reforma Sanitária no tocante à mudança organizativa, que deveria ser mais bem pensada, mesmo porque há certos passos políticos que podem ser inviabilizados pela não-adesão dos atores envolvidos. Os profissionais de saúde, os atores sociais que atuam no sistema, não se sentiram participantes, não foram nem consultados. Foi um movimento que aglutinou certa elite, certo grupo, que caminhou sem muita participação dos profissionais que realmente executam a gestão e os serviços.

Finalmente, deve-se refletir sobre educação não apenas como transmissão de conhecimento, como currículo, mas especialmente em termos de relaçōes sociais, integrando os profissionais de saúde entre si e estes com a população. Quando o médico atende o paciente de determinada forma, quando uma enfermeira ou um assistente social age de uma forma dada, estão, simultaneamente, educando a população, estão transmitindo um modo de conceber saúde e doença. É, sem dúvida, um desafio para a continuidade da Reforma Sanitária, a ser enfrentado concretamente.

Quando se imaginou uma escola como a Politécnica de Saúde, havia a preocupação com o problema da qualidade, talvez em reação a um certo discurso iniciado anos atrás, encampado tanto pela esquerda como pela direita, que defendia a quantidade em detrimento da qualidade. Entretanto, o que se verifica hoje é que aumentou a quantidade, mas não se preservou a qualidade.

A idéia da Escola Politécnica de Saúde era retomar a qualidade, e esse projeto era bastante concreto, uma vez que se pretendia ensinar o que se estava fazendo bem na Fundação Oswaldo Cruz. Trabalharíamos com dez, vinte, trinta alunos apenas, com o objetivo de garantir qualidade, tendo muito claro que a proposta serviria de modelo para que iniciativa semelhante viesse a ocorrer no Instituto Adolpho Lutz, na Usina Siderúrgica de Volta Redonda, nas universidades. Costumávamos dizer: "Queremos que os alunos saiam da Escola Politécnica de Saúde em condiçōes de competir com quaisquer alunos, inclusive os do Colégio São Bento. Não queremos ensino de segunda para gente de segunda". Costaria de ouvir a opinião dos expositores sobre essa proposta.

Um segundo ponto é que, muitas vezes, ouve-se o discurso contra a especialização do médico, contra a técnica muito sofisticada. No entanto, essa é a medicina das elites. Os ricos vão-se operar em Cleveland, a classe média alta vai a São Paulo, buscando sempre as técnicas e os equipamentos mais sofisticados. Independente de se discutir se isso é eficiente ou não, cabe indagar se, ao fazer um discurso em defesa de agentes de saúde, de médicos generalistas, de formas simplificadas de tratamento, não estaremos escolhendo oferecer um atendimento médico de segunda para gente 
de segunda. Mesmo o indio da itha de Bananal também gostaria de se operar em Cleveland, ele só não vai porque não tem condições. Não estaremos, assim, escorregando em novo discurso, subestimando a ansiedade e o desejo dessas populaçōes mais carentes, que é simplesmente sonhar com o acesso à mesma medicina da elite?

\section{Hésio Cordeiro}

A recuperação da qualidade não deve ocorrer apenas no ensino técnico. Atualmente, o ensino médico está profundamente comprometido na sua qualidade. Hoje, muitos sextanistas de medicina não fazem, não gostam e não sabem fazer as tarefas mais simples, como auscultar um coração. Penso que a massificação teve um papel importante nesse tipo de resultado e que é fundamental retomar o tema da qualidade.

Para tentar compatibilizar o problema da formação do pessoal de saúde com a reestruturação das práticas de saúde, penso que uma alternativa interessante a ser testada é a inserção de organismos como a Escola Politécnica de Saúde em instituiçóes que podem aproveitar as suas atividades e formar pessoal de muito boa qualidade, de muito bom nível. Poder-se-ia também pensar, por exemplo, em formar pessoal de nivel médio para a saúde de um modo qualitativamente melhor, mudando a própria concepção da prática de saúde. Essa formação tem que se inserir também no processo de organização dos distritos sanitários. Esse relacionamento seria extremamente desafiante no processo de identificar soluções para a qualificação de pessoal. Imagino que o relacionamento entre projetos ou experiências, como a da Escola Politécnica de Saúde, com certas formas de reorganização da prática de saúde pode ser muito criativo no sentido de buscar a definição de novos profissionais, bem como de contribuir positivamente na maneira como eles devem ser preparados.

A atenção primária, tal como foi vista, pensada e debatida na década de 70, hoje está fora de cogitação. Tem-se que encontrar uma forma de organização das práticas de saúde que considere o que exista de mais efetivo e eficaz em termos de tecnologia, de procedimentos, de equipamentos, de materiais, mas que seja acessivel a toda a população. Devem-se estabelecer critérios objetivos e técnicos que permitam tanto ao indivíduo que ganha um salário mínimo quanto ao capitalista terem acesso a uma ponte safena ou a uma angioplastia. Reafirmo que, fora da política pública, do Estado, não há nenhum outro mecanismo que permita ampliar o acesso da população mais carente, já que o das classes dominantes, das famílias de alta renda, está muito mais bem resolvido, em função de seu poder econômico. 


\section{Cecília Minayo}

Para discutir a questão da qualidade, gostaria de usar um exemplo. Tive uma filha que faleceu de câncer. $\mathrm{E}$, como toda a população trabalhadora, usei os serviços do Hospital Nacional do Câncer, onde minha filha compartilhava o tratamento com colegas mais pobres e necessitados. Do ponto de vista tecnológico, não faltou nada, nem para ela, nem para as demais crianças. Nunca detectei nenhuma forma de discriminação em termos do serviço, de remédios, de atenção das enfermeiras ou dos médicos. Aquele hospital está capacitado para tratar qualquer tipo de câncer, tem um aparelhamento caríssimo, o mais avançado em termos de tecnologia, equiparado ao dos países desenvolvidos. Contudo - e disso reclamo -, nesse hospital, os médicos não estavam preparados para uma visão mais ampla da questão da saúde e da doença.

Havia uma ala do hospital onde minha filha fazia eletrocardiograma. Era um corredor imenso, em que todos, sentados, aguardavam o exame com muito sofrimento. Percebia-se uma representação social de saúde e doença localizada, institucionalizada em um grande prédio. (O máximo a que chegamos na concepção saúde e doença, no sistema biomédico, foi a psicossomática.) No hospital, havia quatro profissionais, entre psicólogos e psiquiatras, com horário parcial, que se limitavam a assinar papéis. Eram burocratas. Sequer consideravam que o câncer afeta a mente, as emoções. Não estavam preocupados com isso, mesmo sabendo-se que, atualmente, há estudos que provam que a questão do câncer está muito relacionada, por exemplo, com o estresse, com problemas que afetam profundamente o emocional. Nem cogitavam que pessoas com câncer incurável, a partir de um atendimento emocional ou de outros tratamentos específicos, ficam curadas e muitas têm uma sobrevida ampliada quando a químio e a radioterapia são acompanhadas de atendimento mais integralizado.

Quando falo de formação humanística, refiro-me à necessidade de considerar que o doente é gente, que gente não é só corpo, que gente não é só pedaço, não é só órgão. $O$ que estou reivindicando é que o centro do pensamento médico seja a 'pessoa' e não a especialidade em si. A especialidade é necessária, temos que ser técnicos altamente qualificados, mas tendo incorporado, como parte da atividade, a dimensão do humano, que deveria ser considerada nos currículos dos diferentes niveis de ensino. Em relação à graduação, parece que isso não está ocorrendo, pois as questōes sociais são secundarizadas, já que as 'matérias médicas' ocupam o tempo todo e motivam mais. Não estou afirmando que se devam introduzir disciplinas da área das ciências sociais no currículo. Entretanto, parece-me crucial que essa concepção humanística informe todo o processo de formação do profissional de saúde. 



\section{RELAÇÕES DE TRABALHO NO SETOR SAÚDE}





\section{EDUCAÇÃO E SAÚDE: DIMENSÕES DA VIDA E DA EXISTÊNCIA HUMANA}

Joaquim Alberto Cardoso de Melo

Discutiremos a saúde do ponto de vista da educação a partir de duas colocaçōes: a dicotomia entre saúde pública e assistência médica, e a educação como elemento constitutivo das relaçōes sociais.

Educação e saúde são áreas que não se separam. A educação é parte integrante das relações sociais, $e$, tanto na educação quanto na saúde, as relaçöes de trabalho se dão em torno de práticas. As concepçōes oficiais, dominantes, das representaçōes desses fenômenos variam segundo as classes sociais. As classes populares possuem uma representaçăo mais ampla da saúde, enquanto o discurso oficial corresponde a uma representaçăo (ou conceituação) de saúde mais restrita, fragmentada, pontual, centrada no modelo biomédico, que busca localizar a doença em algum ponto ou órgão do corpo das pessoas.

Cecília Minayo, no texto "Saúde e sociedade", faz uma reflexão sobre saúde como prática social, fornecendo um histórico do surgimento da saúde pública. As açōes ou as políticas públicas de saúde inicialmente foram açōes de controle do Estado sobre o meio ambiente. É a partir de dados de mortalidade, de epidemias e de suas relaçōes com as condições de vida e trabalho das populações dos séculos dezoito e dezenove que se vai constituindo a saúde pública. Até os anos 20, essas açōes do Estado ocorrem com o objetivo de sanear as cidades e os rios, higienizando os espaços urbanos, os corpos e as mentes das pessoas. Resolvidos os problemas de saneamento, surge então a saúde pública, o movimento sanitário, não no sentido atual, mas como uma nova etapa, mais voltada para o controle não apenas das doenças epidêmicas ou ligadas ao meio ambiente, mas também para o controle de doenças crônicas, cardiovasculares, diabetes, e de vetores.

A dicotomia entre saúde pública e assistência médica sempre existiu no Brasil. Constata-se que a assistência médica começa a ser organizada somente no início deste século, muito depois, portanto, do surgimento da saúde pública. Nos anos 20, com a reforma Paula Souza, em São Paulo, e a implantação do primeiro Centro de Saúde na América Latina, também em São Paulo, começa-se a discutir se 
o atendimento médico deve ser de caráter público ou privado, no mesmo movimento em que se coloca a questão da escola pública. Quer-se definir se a atenção médica será incorporada pelo Estado, junto com as ações de controle sobre o meio, ou se essas ações médicas serão essencialmente curativas. Ou seja: a discussão começa a se configurar no âmbito (ou no limite) da assistência médica, estabelecendo, de um lado, as ações curativas e, de outro, as ações preventivas, ligadas às ações tradicionais da saúde pública.

Na década de 60, particularmente em 1967 e 1968, os recursos para a saúde pública são bastante reduzidos e, coincidentemente, aumenta o volume de recursos para a área da assistência médica, ocorrendo ainda a unificação dos institutos previdenciários. Isso, de alguma forma, já traduz certa incorporação de aspectos preventivos à chamada medicina curativa.

Tal situação coincide, de um lado, com a decadência da saúde pública clássica e, de outro, com o crescimento de interesses no sentido da unificação das áreas preventiva e curativa, não na forma de organização do serviço, mas incorporando aspectos preventivos à prática médica. É o momento em que os departamentos de Medicina Preventiva, valorizados, se reorientam, se oxigenam, incorporando uma série de discussóes e, também, iniciando uma crítica ao modelo vigente. Inaugurase, assim, uma área da medicina social. Com o crescimento do INPS (depois Inamps), o enfoque da saúde pública volta-se para a assistência médica, não abrangendo mais as questões de controle do ambiente. Nesse contexto, o movimento sanitário e os núcleos de saúde coletiva que se estăo criando nos Estados ocorrem sob enfoques médicos, restringindo a saúde ao âmbito da assistência médica, embora, ao longo da sua históri:, cla não se tenha sempre apresentado dessa forma.

Durante o período em que a saúde teve como alvo principal o controle do ambiente, ela constituiu muito mais um problema de engenharia sanitária do que de medicina. Os próprios serviços de saúde pública tinham um profissional para a zona rural, chamado inspetor sanitário, um profissional de nível médio, de nível técnico, que exercia funçōes de engenheiro no controle das doenças. Hoje, não só a maneira como a própria Escola Nacional de Saúde Pública da Fiocruz se organiza e as modalidades de cursos que oferece, mas também o espaço que o Departamento de Ciências Biológicas perdeu nesses cursos indicam um esvaziamento das questões da saúde pública. Esse esvaziamento, ainda que por pouco tempo, foi acentuado e reforçado no período da ditadura, pois tudo o que representava controle do Estado era visto como reprodução da ideologia das classes dominantes e autoritarismo.

Mais recentemente, começam a surgir movimentos que reivindicam a necessidade de controle da ação do homem sobre o meio ambiente, bem como de controle da produção de agrotóxicos e de medicamentos. São áreas que não estão sendo formalmente contempladas e que constituem um campo que, de certa maneira, encontra muita oposição e resistência. Defender a natureza, buscar formas 
alternativas de produção ou controlar a produção são temas sem muita repercussão, como se ecologia não constituísse matéria relevante.

No início do desenvolvimento do capital, para que ele pudesse se expandir, necessitou-se controlar o ambiente. Exemplo clássico no Brasil é o da ex-Fundação Serviços Especializados de Saúde Pública (FSESP), um serviço complexo e interessante, que, durante anos, foi tomado como padrão de qualidade e de organizaçăo, saneando o meio e protegendo o trabalhador das doenças, criando condições saudáveis para a exploração da borracha e dos minérios. Atualmente, o controle sobre o meio restringe-se, fundamentalmente, ao controle do processo industrial de produçăo, processo este que não só coloca em risco as condições de vida do planeta, como também implica o controle sobre o capital, os processos de trabalho, os processos de exploração da relação homem-natureza e das relaçōes homem-homem.

A escola do setor saúde deve ser uma resposta a essas preocupações. Num certo momento, entendia-se que ela - em particular a escola médica - tinha que atender ao mercado de trabalho, como se fosse um reflexo mecânico determinado por este mercado, o que constituía um falso entendimento, porque, se por um lado ela é isso, por outro também pode apontar ou criar uma outra maneira de pensar a formação dos profissionais.

Não há essa relação permanente, mecânica, a escola não é tão passiva em face da realidade do mercado de trabalho. O setor saúde é um complexo, e a saúde pública tem, de maneira ainda pouco dinamizada, muito amortecida, espaços de ação sobre o meio. Existe hoje, na Secretaria de Saúde do Estado do Rio de Janeiro, um setor de vigilância sanitária, com veterinários, farmacêuticos, laboratórios, que, entretanto, não discute temas relacionados ao controle da qualidade dos medicamentos, do sangue, dos alimentos. Em São Paulo, o setor de vigilância sanitária, com uma tradição bem maior, mantém uma concepção bastante conservadora. As ações desse setor recaem principalmente sobre o controle da prática profissional, refletindo uma preocupação com a profissão, e não com a produção e a qualidade do produto ou com os riscos desses produtos para a saúde dos consumidores.

Deve-se, portanto, pensar a formação técnica profissional para além do âmbito da saúde e pensar saúde pública para além do âmbito da assistência médica. A unificação do Inamps e do Ministério da Saúde pode significar, de um lado, a unificação da assistência médica, mas esta não se confunde com a saúde pública ou com o dever do Estado de controlar qualidade da produção, no sentido mais abrangente. É preciso pensar saúde também para além das condições meramente materiais de existência, de classes, grupos ou indivíduos, e até a partir do próprio modo de produção, para encontrar limites ou transformaçōes desse modelo da relação homemhomem-natureza, avaliando os riscos do desaparecimento das condições de sobrevivência da espécie humana. 
A população e os profissionais de saúde têm representaçöes próprias de saúde, de doença, do corpo, da vida, da morte. Ambos os segmentos criam suas metáforas, têm seus preconceitos, adiotam uma visāo particular de mundo, do homem nesse mundo e do serviço de saúde. Constitui-se, assim, um universo de representações diferenciadas, muitas vezes antagônicas, visto que a posição de classe do médico, aparentemente unificada em um discurso pontual, espacial, desumanizador, fundado numa ordem biomédica, submete pacientes e demais profissionais de saúde. Mas submetidos näo quer dizer reduzidos a ele. Nas relações de trabalho, impera o discurso dominante mediador, um discurso médico, organizado segundo uma ordem médica, com açōes práticas e técnicas específicas, aparentemente um discurso que unifica e que organiza as relações entre profissionais de saúde e pacientes. Essas relações, porém, não se reduzem ao interior do discurso, ou seja, tanto os profissionais de saúde como os pacientes irão se relacionar enquanto seres sociais, e outros discursos, outras representações estão em jogo. Há uma esfera mais abrangente no agir social, que é uma interação de representaçōes, constituindo um complexo de relações sociais entre profissionais de saúde, pacientes e instituiçăo. Instituição essa em cujo discurso o sujeito é sempre indeterminado: fala-se, diz-se, pensa-se, faz-se.

Pensar, entăo, as relaçōes de trabalho na saúde ou na educaçăo significa redimensioná-las para além do discurso racionalizador, instrumental, seja ele da pedagogia ou da medicina. Existe um complexo de relaçöes dos seres sociais com suas representaçōes de mundo, de ordem, de vida, de doença, que estão criando resistências, oposiçōes, negaçōes. Analisar o trabalho numa empresa, numa instituição pública ou numa escola é refletir sobre essa dimensão social em que, junto com as representaçóes do que sejam a ciência e a técnica, existe um complexo de relaçōes intersubjetivas de seres sociais. É, portanto, um espaço de lutas, de confrontos, de resistências, de antagonismos, de visōes de mundo diferentes, um espaço de relações de hegemonia e de construção de hegemonias.

Pensando saúde e educação como uma articulação com a vida e a existência, é interessante atentar para o fato de que os gregos possuíam dois vocábulos diferentes para expressar o conceito atual de vida. Um deles - physis (uma lei geral para todos os fenômenos) - correspondia à vida orgânica, cósmica; o outro - bios - integrava representaçōes, idéias, pensamentos, formas de existência humana, bem como valores éticos e morais. O mundo helênico năo se restringia, pois, a uma ordem cósmica, havia uma diferenciação da vida da sociedade humana dentro dessa ordem maior. A partir do racionalismo moderno, o homem se destinou uma nova inserção no universo, como ser mais complexo, mais perfeito, o animal racional que se diferencia de todos os outros.

Aprende-se na escola como o mundo é dividido: há os seres vivos e os inanimados, os seres racionais e os irracionais, os úteis e os nocivos ao homem. A construção dessa visão do mundo, na qual o homem se atribui o papel de criador, contribui 
para que 'esqueçamos' que a vida não é apenas humana, e a saúde não é um atributo exclusivo do homem. A vida está para além do homem, numa interdependência com outros seres, isto é, o mundo inanimado não é tão inanimado assim, ele é parte da constituição do ser humano. Então, a vida é o complexo constituído da relação entre esse chamado 'mundo bruto' e os seres vivos. A depredação ou o esgotamento desse 'mundo bruto' significa o esgotamento da vida, já que as condições de vida năo se restringem apenas ao âmbito do humano: são condições de vida e de saúde das espécies em geral e de um modo de vida do próprio planeta, planeta como uma construção da vida.

A existência, por outro lado, é particularidade do homem, só o homem a constrói, e o processo de produção e reprodução dessa existência é o processo de educação. A educação constitui-se nos processos pelos quais os humanos 'arquitetam' sua existência, que, embora se construa enquanto vida, não se impõe ou sobrepöe como forma única possivel, como que independente das demais condiçōes de vida e saúde do próprio planeta. Vida e saúde são sempre interligadas: vida é saúde, saúde é vida; vida é educação, educação é vida; educaçăo é saúde, saúde é educação. Essa complexidade do que seja vida e saúde, educação e existência é uma questão imperiosa para quem trabalha com a saúde e, portanto, com a vida. 



\section{AS DIMENSÕES DO TRABALHO EM SAÚDE}

Roberto Passos Nogueira

Discutirei dois temas que continuam a ser muito instigantes, apesar de não estarem mais em voga na esfera acadêmica. O primeiro, a questão da teoria, assunto que vem perdendo prestígio devido à crise do racionalismo contemporâneo. $O$ segundo, a questão do trabalho, categoria essencial na economia clássica e para os filósofos clássicos do século dezenove, que vem sendo relegada ao esquecimento pelos snciólogos. ${ }^{1}$ Entretanto, como tenho uma veia clássica que, ao mesmo tempo, conflitua e compactua dentro de mim com uma tendência de viés pós-moderno, interessa-me muito ainda o problema do trabalho em saúde, mas creio ser necessário abordá-lo a partir da revalorização de certos elementos vivenciais.

Não discordo da tese de Joaquim Cardoso de Melo de que a saúde pública, ao longo de sua evolução nos últimos anos, negligenciou a questão do meio ambiente e sua importância no currículo dos cursos que oferece. Faz-se premente recuperar o espaço dos problemas ambientais no ensino de saúde pública, mas isso deve ser combinado com um tratamento adequado do tema da assistência médica. Os cursos de saúde pública limitam-se, em geral, a uma espécie de propedêutica da assistência à saúde, sem entrar de fato em suas dimensões técnicas efetivas. Por exemplo, no que se refere à avaliação e à organização dos serviços, privilegiam-se, freqüentemente, os aspectos de políticas de planejamento e de gerência, enquanto a questão técnica da ponta é esquecida.

Este é o grande desafio para a renovação das práticas educativas em saúde pública: como aprofundar tecnicamente o tema do cuidado de saúde e incorporar a temática ecológica, que hoje não pode se ater apenas ao controle dos agentes transmissores de doenças, devendo, também, abarcar todos os possíveis danos à qualidade do meio ambiente.

1 Os interessal'os no tema da perda de centralidade da categoria trabalho devem consultar o artigo de Klaus Offe, na coletânea Capitalismo Desorganizado. 
Insisto na importância do entendimento técnico dos serviços de saúde, no que eles dependem do processo de trabalho nesta área, e este é o foco principal desta discussão.

Ao analisar o processo de trabalho em saúde, é necessário considerar três aspectos fundamentais. Em primeiro lugar, ele é um exemplo do processo de trabalho em geral e, portanto, compartilha características comuns com outros processos que ocorrem na indústria e em outros setores da economia. Segundo, ele é um 'serviço', já que toda assistência à saúde constitui um serviço. Terceiro, é um serviço que se funda numa inter-relação pessoal muito intensa. Há muitas outras formas de serviço que dependem de um laço interpessoal, mas, no caso da saúde, ele é particularmente forte e decisivo para a própria eficácia da ação.

Essas três dimensōes são complementares e interatuantes. De um lado, temse um processo de trabalho, com sua direcionalidade técnica, envolvendo instrumentos e força de trabalho, sendo passível de uma análise macroeconômica geral, na forma efetuada por Marx em O Capital. Nessa obra, encontram-se elementos para analisar igualmente o processo de trabalho em saúde, inclusive em suas questōes complexas de composiçăo econômica e técnica do capital, bem como da dinâmica das trocas, que têm também uma correspondência no setor saúde.

Mas há uma outra dimensảo, que é a do serviço. A assistência à saúde não é um processo de trabalho igual ao da indústria, ela tem uma especificidade por ser um serviço. Esta palavra tem por trás de si uma tradição quase pejorativa: serviço vem de 'servo'. Por outro lado, a economia clássica praticamente não se preocupou com a análise teórica do que fosse serviço, porque, dentro da dinâmica da acumulação capitalista do século dezenove, esse não era um setor decisivo. Entretanto, atualmente, ele adquire extrema importância e, sem dúvida alguma, é o que marca a própria modernidade do capitalismo. $O$ setor saúde talvez seja um dos mais peculiares a essa nova forma de sociedade baseada na proeminência do trabalho em senviços.

$O$ terceiro aspecto advém do fato de esse serviço não se realizar sobre coisas, sobre objetos, como acontece no caso de um serviço de mecânica de automóveis. Dá-se, ao contrário, sobre pessoas e, sobretudo, com base numa inter-relação em que o consumidor contribui no processo de trabalho, é parte desse processo, na medida em que fornece valores de uso necessários ao processo de trabalho. Exige-se dele não só informação acerca do que the ocorreu, a história de sua queixa ou doença, mas também participação ativa para que sejam corretamente aplicadas normas e prescrições médicas. Assim entendida, a assistência é também um processo de profunda inter-relação entre quem consome o serviço e quem o presta. Mais tipicamente do que em outros setores da economia de serviço, encontra-se aí o fato peculiar de que o usuário é um fornecedor de valores substantivos de uso, de tal modo que ele é co-partícipe do processo de trabalho e, freqüentemente, co-responsável pelo êxito ou malogro da ação terapêutica.

A idéia de processo de trabalho em saúde é algo extremamente abstrato, porque existem inúmeras formas tecnicamente particularizadas de realizar atos de 
saúde. Considere-se, por exemplo, como são diferentes as ações de saneamento e as de atendimento médico. Por isso, é preferivel tratar das formas mais homogêneas e falar apenas dos serviços de saúde propriamente ditos.

Há que se afirmar, em primeiro lugar, que esse processo é marcado por uma tecnicalidade ou direcionalidade técnica inerente a qualquer processo de trabalho humano. Pressupōe, assim, uma antevisão dos resultados almejados e uma ação inteligente como ardil da razão em sentido hegeliano: fazer com que os instrumentos físicos, químicos, bioquímicos atuem sobre o objeto, produzindo um efeito útil. $\mathrm{O}$ ardil da razão tem por fundamento certos conhecimentos científicos, mas requer uma adaptação constante às características particulares: este indivíduo 'aqui', com sua história e necessidades. Isso já suscita de imediato a questăo do serviço na medida em que traduz a adequação constante ao particular, no sentido não só do indivíduo como ser, mas também das circunstâncias em que surgem seus problemas ou necessidades.

A direcionalidade técnica tem atualmente uma natureza coletiva, porque um conjunto de categorias e de indivíduos procura agir coerentemente, compartilhando os conhecimentos científicos contemporâneos. Contudo, sabe-se que apenas determinada categoria controla o processo de trabalho em saúde a partir de sua autoridade técnica e social: a dos médicos. Mesmo quando não são proprietários dos meios de produção donos de clínicas ou de hospitais -, os médicos têm a faculdade de comandar o ato técnico em saúde, no que se diferenciam dos demais trabalhadores.

Outra particularidade do trabalho em saúde deve ser sublinhada: a integração entre seus aspectos intelectual e manual. Ao contrário de outros processos de produção, na saúde quem detém a direcionalidade técnica também 'põe a mão na massa', ou seja, participa diretamente do ato técnico final (compare-se, por exemplo, com o papel de um engenheiro numa fábrica). Isso não significa que não exista separação entre esses dois aspectos em termos funcionais mais globais. De fato, as tecnologias atuais vão reservando aos médicos certas funções mais intelectuais - como interpretar uma chapa de radiodiagnóstico -, deixando aos auxiliares as operacionais - como produção e revelação dessa chapa. Mas, ao analisar o conjunto dos trabalhadores, compreende-se que essa separaçăo não é generalizada, o médico continua a ser um trabalhador manual na cirurgia, na clínica e em muitas outras áreas.

Outra característica muito particular do processo de trabalho em saúde é a fragmentação dos atos. Num hospital ou numa clínica, o usuário tem que passar por uma quantidade enorme de atos de diagnóstico e de terapia para ter seu problema resolvido. Sabe-se que, usualmente, isso implica o deslocamento físico dele, de um setor a outro, dentro da mesma unidade produtiva ou entre estabelecimentos distintos. A saúde não é uma área que funciona segundo a lógica de substituição de tecnologia por trabalho. A tendência geral é a de acúmulo das novas 
tecnologias e de variedade de serviços. Daí, o sentido de fragmentação da prestação e do consumo de serviços de saúde.

Se, de um lado, o sentido, o porquê de cada ato escapa ao usuário, de outro, há uma profusão infindável de tipos parciais ou autônomos desses atos. Desse modo, ele tem que percorrer um labirinto de serviços e obter uma coisa aqui, outra ali, ignorando a finalidade dessas intervenções executadas sobre o seu corpo. Além disso, ainda é solicitado a colaborar.

Onde está, nesse torvelinho, a direcionalidade técnica do trabaiho em saúde? Encontra-se profundamente dividida e fraturada, do ponto de vista tanto do trabalhador como do consumidor. A vivência do consumidor diante desse monstro que é o aparato de assistência médica torna-se ainda mais dramática na medida em que se espera que ele preste informaçōes, siga ordens, execute certos atos e se esforce em colaborar. Entretanto, seguramente, ele se pergunta: colaborar para quê? Onde se quer chegar com toda essa parafernália?

Nesse sentido, os serviços geram um enredo de alienação muito semelhante às situações clássicas abordadas por Marx no século passado, situações essas que hoje já não são tão peculiares ao trabalhador produtivo.

Discussão fundamental a ser realizada em relação ao trabalho em saúde é a do seviço. Afinal, o que é um serviço? Na definição genérica dada por Marx, serviço é o efeito útil de alguma coisa, mercadoria ou trabalho. É o que resulta da utilização de bens ou da força de trabalho em seu aspecto de valor de uso. Na sua origem, a idéia de serviço estava muito presa à de serviço pessoal: serviço de uma empregada doméstica, de um advogado e assim por diante.

Em certa medida, os serviços de saúde parecem-se com esses serviços pessoais, porque requerem uma íntima relação interpessoal, mas envolvem um consumo intenso de mercadorias, o que os situa numa dimensão mercantil distinta. $\mathrm{O}$ serviço de saúde nunca resulta de uma aplicação de regras gerais a um processo de trabalho genérico. Ele pressupõe, ao contrário, uma aplicação de conhecimentos ao particular, ao caso, numa forma de inter-relação em que o usuário fornece alguns valores de uso e também participa ativamente do processo. O que se obtém são certos efeitos úteis, observáveis ou presumidos, em determinado período de tempo. Por outro lado, o que se compra e vende são esses atos úteis. Deve-se pagar por todas essas mercadorias - medicamentos, materiais diversos, equipamentos etc. -, núcleo dos distintos processos de trabalho envolvidos no diagnóstico e na terapia. $O$ usuário paga pelo efeito útil presumido na medida em que sela um pacto de cientificidade com a medicina moderna e seus prestadores, raciocinando mais ou menos assim: "aceito que essa multiplicidade de atos, cujas razões e objetivos específicos desconheço, terá um resultado positivo sobre meu estado de saúde".

Não interessa, do ponto de vista da lógica econômica dos serviços, se esses atos, em sua multiplicidade fragmentada, terão um efeito final efetivamente útil ou não - a utilidade é presumida em função do pacto de cientificidade com a 
medicina, que é totalmente distinto do pacto que se estabelece com um curandeiro, a quem também se costuma remunerar pelos serviços. Assim, em relação à medicina moderna, o usuário pagará pelo valor dos bens materiais utilizados e pelo uso da força de trabalho preparada segundo os padrǒes correntes.

Desse modo, ao lado da fragmentaçăo vivencial, aparece uma outra, de natureza econômica. Quando o pagamento por esses atos múltiplos e variados é efetuado por meio do seguro privado ou social, o que surge daí é o problema de como realizar um controle efetivo sobre eles, já que, nesse caso, a utilidade náo pode ser meramente presumida. Ela deve-se adaptar a certas normas técnico-científicas e administrativas estabelecidas pelo contratante.

Mas é extremamente complexo regular a produção desses serviços caso não se tenha certa flexibilidade. Não se pode desconhecer que cada ato é uma aproximação do particular, havendo sempre um razoável desvio a partir da média. Por outro lado, hoje já năo se pode admitir, como fazia a antiga medicina liberal, que o trabalho médico deva ser totalmente livre e se pautar exclusivamente pelo arbítrio clínico do profissional. O controle da fragmentação dos atos médicos requer, assim, um grau de inteligência e de habilidade técnica muito grande. Este é um dos maiores problemas atuais no desenvolvimento dos seguros de saúde, sejam privados ou públicos: estabelecer modalidades 'clinicamente' justas de remuneraçāo dos serviços. Como continuar remunerando os serviços de saúde segundo normas que não prejudiquem esse pacto de cientificidade firmado com o usuário que espera ver restabelecida sua saúde? Uma das tentativas recentes é a construção dos chamados "Grupos Relacionados com o Diagnóstico" (Diagnostic Related Groups), nos Estados Unidos e na Europa, cuja viabilidade de introdução no Brasil vem sendo estudada pela Escola Nacional de Saúde Pública/Fiocruz.

Administrar uma unidade hospitalar ou uma rede de serviços contratados por seguro não constitui tarefa simples. Nāo só devido à já mencionada fragmentação dos atos técnicos, com suas implicações econômicas, mas também porque a direcionalidade técnica desses atos depende em si mesma do comportamento de uma categoria profissional - os médicos - que normalmente faz um uso corporativo desse poder.

Finalmente, voltamos à questão da inter-relaçāo pessoal, esse diálogo singular que sempre tem que existir, não só entre o médico privado, o clínico e seu usuário, mas também esse diálogo singular, universalizado, que se deve travar entre trabathador coletivo e usuários dos serviços de saúde. Esse é um tema que foi muito discutido - de forma idealizada e ideologizada - pela medicina liberal. O pressuposto é o de que ninguém pode ter a faculdade de controlar esse ato de diálogo, porque ele sempre tem que se dar a partir de cada situaçāo particular. No entanto, sabe-se que isso não só é possivel ética e politicamente, como também é uma exigência da organização moderna dos serviços de saúde. Como um hospital ou um sistema de saúde pode estabelecer uma ética de trabalho em relação ao indivíduo 
que necessita de cuidado de saúde que não seja a ética liberal, que não seja a ética da livre escolha por uma confiança absoluta no médico particular? Esse problema pode ser resolvido por meio de um pacto político entre trabalhadores de saúde e dirigentes, por meio de uma nova ética de comportamento diante das necessidades e demandas dos usuários.

Esse é o limite da área de recursos humanos em saúde. Pode-se examinar a questão do processo de produção dos serviços de saúde com uma visão bem geral. Pode-se trabalhar com a questão dos serviços, com a administração dos serviços, com base numa longa aprendizagem. Entretanto, quando se chega à dimensão pessoal, entra-se no campo puramente ideológico (e, dentre as ideologias consagradas, uma é a da medicina liberal). $E$, então, há que se pensar em novas formas de harmonizar os trabalhadores com a clientela, e a responsabilidade institucional com os anseios dos trabalhadores. Esse é um dos desafios que a Reforma Sanitária enfrenta hoje no Brasil.

Se as condiçōes de trabalho melhoram para os trabathadores, como assumir uma nova ética profissional (exigência decorrente dessa mudança)? De que modo abordar esse diálogo que se estabelece com o indivíduo que sofre, que vem ao serviço de saúde com suas preocupações, cheio de expectativas de que esses atos fragmentários possam resolver os problemas? Então, esse é o limite, limite para o qual não existem regras, para o qual há procedimentos, há experiências políticas, mas que depende da sabedoria dos dirigentes, dos líderes sindicais inclusive e também de um processo histórico de construçăo de uma nova consciência, sobretudo dos médicos, para vencer a etapa liberal e mesmo conflitar com a neoliberal que aí está.

É necessário, entăo, refletir constantemente sobre essa dimensão porque ela complementa todas as outras envolvidas no processo de trabalho de saúde - no nível técnico, no nível do processo de trabalho em geral e no nível do serviço como aproximação ao individual. Como se deve dar numa forma coletiva essa aproximação, esse diálogo com o paciente, de tal forma que ele realmente participe do processo de uma forma menos alienada? Porque o objetivo deve ser tratar o usuário não como um simples objeto, mas como um colaborador efetivo da prestação de serviços de saúde. 


\section{DEBATE}

Entendo que a exposição de Roberto Passos Nogueira constata algumas contradiçōes. Dentre elas, a especificidade do processo de produção dos serviços de saúde, em que o usuário é também partícipe. Mas, por outro lado, e cada vez mais, o serviço é definido pela tecnologia, que, por sua vez, fragmenta e exige a participação de sujeitos novos para atendimento ao paciente, atendimento que tem a particularidade de ser individualizado.

Assim, a primeira contradição é que, paradoxalmente, aquilo que chamamos de tecnologia e de cientificidade e que ajudaria a resolver alguns problemas estaria, na verdade, agravando outros. Em outros termos: o processo de especialização cria o risco, pela fragmentação, de perda do objeto, agregando complicadores à questão inicial. A contradição se amplia quando se atenta para o fato de estarmos em face de um problema político, de certa mistificação da relaçāo paciente-médico, em especial do paciente em relação ao profissional que pode resolver a sua situação.

Como saída para essa situação, é apontado o surgimento e o fortalecimento de uma nova consciência em relação ao que pode significar o serviço público de saúde. A qualidade desse serviço não ficaria mais restrita ao desempenho do médico, mas seria conseqüência também de condiçôes de trabalho, da forma de incorporação e utilização de novas tecnologias etc. A ação política demandaria a compreensão do usuário como sujeito coletivo, concebendo-se a saúde pública na perspectiva dessa nova consciência, que inclui tanto o médico quanto o usuário. Um grande problema dessa política é que os usuários criam seus bruxos, e esse não é mais um problema médico, nem de saúde, é um problema de cultura geral.

Roberto Nogueira, em outro trabalho, aborda duas visões distintas ao analisar os trabalhadores de saúde: força de trabalho e recursos humanos, uma na ótica da 
teoria de sistema e a outra na visão marxista, focalizando, ainda, como uma questão menor, a própria expressão 'recursos humanos'. Concordo em parte com isso. Com certeza, a denominação não é o fundamental, principalmente quando trabalhada só do ponto de vista formal. Existe, porém, uma relação entre a forma e o conteúdo, ou seja, entre a própria denominação e o objeto a que ela se refere.

Considero interessante essa linha de raciocínio que estabelece as distinções, porque há uma tendência a fazer uma leitura bastante mecânica do que Marx escreveu no século dezenove. É interessante fazer a distinção entre a lógica da produção que Marx trabalhou em O Capital e aquela que está colocada para o setor serviços.

Encontro uma tendência do que vem ocorrendo no setor produtivo a se tornar dominante também nos serviços, tanto pela divisão técnica do trabalho, quanto pelo permanente avanço tecnológico. Nos Estados Unidos, está começando a aparecer uma nova categoria profissional, que se situa entre o médico e um auxiliar, o que é uma tendência a transportar a lógica da produção para os serviços.

\section{Roberto Passos Nogueira}

A questão levantada remete a uma intensa discussão, ocorrida no início dos anos 80 , acerca das diferenças entre abordagens centradas na 'força de trabalho' e em 'recursos humanos'. A esse respeito, escrevi um trabalho afirmando que esses enfoques não são necessariamente conflitantes.

'Força de trabalho em saúde' remete ao nivel macroeconômico da demografia, da economia clássica, que procura ver a dinâmica dessa força no mercado. Analisa a questão do emprego em saúde na sociedade, como ele se distribui pelos vários tipos de instituição do setor e co-relaciona o emprego em saúde com o emprego na sociedade em geral, dentro de uma visăo macro que, ao mesmo tempo, é analítica e descritiva. 'Recursos humanos' resultam de uma intervenção maior no nivel institucional, procurando planejar, gerenciar a força de trabalho, situada principalmente no nivel microinstitucional.

Nesse mesmo artigo, enfatizo que as duas abordagens deveriam conviver, desde que o enfoque intervencionista de recursos humanos incluísse a análise da força de trabalho em saúde. O problema é que, tradicionalmente, na análise de recursos humanos, toma-se, como ponto de partida, a preocupação em intervir, e, assim, não se examina a força de trabalho em saúde na sociedade com um todo, isto é, a dinâmica da totalidade desse processo. Não se aprofunda a discussão dessa força de trabalho, nem do setor saúde em geral, nem das categorias profissionais isoladamente. Essa concepção é prescritiva a priori e, às vezes, bastante superficial. Quantifica "tantos médicos por leito, tantas enfermeiras por leito, tantos médicos por habitantes" e postula uma série de critérios de intervenção na gerência de pes- 
soal, sem avaliar não só a dinâmica específica dessa força de trabalho, mas também a esfera institucional.

Em outras palavras, não me parecem conflitantes as duas abordagens, desde que uma delas, a de força de trabalho, preceda, esteja presente no pensamento de quem esteja falando e intervindo em recursos humanos. Nosso esforço pedagógico tem sido esse. Dizer "vamos trabalhar com recursos humanos porque temos compromissos com as mudanças do setor" significa assumir um comprometimento com as políticas de recursos humanos, com as políticas de saúde de modo geral. Mas esse compromisso pressupóe uma análise profunda do que está acontecendo com a questão da força de trabalho em saúde no País. 


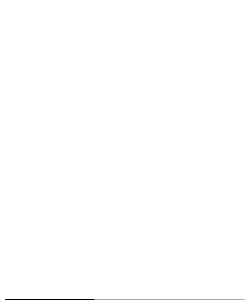




\section{FORMAÇÃO PROFISSIONAL: DIAGNÓSTICO E PARTICIPANTES}




\title{
O NOVO PARADIGMA DA ORGANIZAÇÃO DO TRABALHO E A FORMAÇÃO PROFISSIONAL NA ÁREA DA SAÚDE
}

\author{
Maria Umbelina Caiafa Salgado
}

Para esta exposição, pensei em apresentar um quadro amplo, a partir do qual se pudesse analisar o problema da formação profissional na área da saúde. Surpreendi-me, porém, com o fato de encontrar pouquíssimos registros sobre a formação de técnicos de nível médio e elementar nessa área, apesar da existência de um infindável número de pessoas com esses graus de escolaridade trabalhando em postos do sistema de saúde. O material encontrado trata do médico, da enfermeira ou do odontólogo, observando-se uma surpreendente lacuna em relação ao pessoal de nível médio.

Além da responsabilidade, da importância do trabalho e até do risco que o usuário do serviço corre em funçăo de uma possível não-qualificação desse técnico, a mencionada escassez de estudos certamente deve dificultar a organização, a proteção e a defesa desse indivíduo enquanto trabalhador. A área da saúde precisa ser examinada com mais atenção. Na atual Constituição, houve ganhos, mas é necessário que se possa fazer valer esses ganhos e cobrar do Estado as responsabilidades que lhe cabem, principalmente seu papel na prevenção e na democratização do acesso aos serviços de saúde.

A partir de pesquisas que venho realizando sobre o profissional de nível técnico, analisando sua inserção diante da realidade brasileira atual, pretendo apontar as especificidades dessa formação na área da saúde dentro do quadro econômico, político e social do País.

A educaçāo básica, especificamente a de nível médio, tem que ser tratada no quadro de sua relação com a organização do trabalho. Considero que as questōes do trabalho, da participação e da cidadania têm de ser discutidas a partir da análise da organização do processo de trabalho e das relaçōes sociais subjacentes.

Essa discussão é importante porque permite, por exemplo, tratar alguns assuntos relacionados com o estágio de desenvolvimento científico e tecnológico do País, observando onde ele existe, onde é mais danoso para a sociedade brasileira, como pode afetar a saúde da população. Além disso, permite captar as contradiçôes 
e mediações que permeiam os processos de organização do trabalho, a reestruturação ocupacional da economia e a própria forma de controle social da força de trabalho, que acompanha esses processos. Possibilita, ainda, propor alternativas de formaçăo profissional que levem em conta os interesses da coletividade e não apenas os dos setores produtivo ou empresarial. Finalmente, essa análise permite considerar as especificidades de uma situação histórica concreta. O Brasil, enquanto país periférico, sofre as contradições, os desequilíbrios de uma modernização dependente e, além disso, é uma sociedade de classes antagônicas, dado importante que năo pode ser esquecido. Assim, tentarei caracterizar o capitalismo contemporâneo e os modos como são afetadas por ele: a estrutura do setor industrial, a estrutura do setor terciário, incluindo o serviço de saúde, e, por último, a profissionalização.

Estamos vivendo um momento importante, em que o paradigma da organização do trabalho, baseado na extrema segmentação do modelo fordista/taylorista, está alcançando seu limite. Esse paradigma teve sua fase de implantação, nos Estados Unidos, do início do século até a Primeira Guerra e, na Europa, nos anos intermediários entre as duas guerras. Sua disseminação pelo resto do mundo deu-se nos anos do pós-guerra. A partir da década de 60 , começou a apresentar sinais de decadência, observando-se hoje a transição do paradigma da produção em massa para um novo paradigma, o da produçāo flexível.

Algumas características permitem revelar em que consiste o paradigma que ora se vem esgotando. Primeiro, o refinamento da cooperaçăo baseada na divisăo do trabalho, portanto cooperação mecânica, nāo-orgânica, alienada, leva à concentração dos meios de produção e à centralização das decisôes. Tal modelo resulta na oligopolização da economia, ou seja, na organização de grandes grupos ou de grandes unidades produtoras, gerando uma estrutura do setor industrial integrada horizontal e verticalmente. Verticalmente no sentido da tendência das empresas a produzirem desde a matéria-prima até o produto final ou, quando isso não ocorre no âmbito da mesma empresa, mediante uma articulação setorial bastante estreita, de tal maneira que o insumo de uma empresa é o produto de outra. Esse processo de centralização, de concentração, acaba por gerar, intrinsecamente, uma série de problemas de funcionamento, porque ele é baseado na produção em massa e deve ter um consumo de massa. É concentrador de capital, mas, ao mesmo tempo, depende de certo grau de distribuição para viabilizar o consumo necessário.

Um fato importante é que, nos países do Primeiro Mundo, a oligopolizaçāo precedeu a internacionalização, enquanto nos países subdesenvolvidos se observa o contrário: a decisão de internacionalizar é que acarreta a oligopolização da economia. Isso é muito mais dramático, mais selvagem, porque não existe qualquer anteparo que possa reduzir a violência do choque. Embora o capitalismo sempre tenha tido esse caráter de internacionalidade, é a partir do período identificado com a Segunda Guerra que se constitui um verdadeiro sistema internacional, incluindo o capital financeiro e incorporando os países do Terceiro Mundo como dependentes 
ou periféricos. Estes passaram a fazer parte do sistema internacional enquanto unidades desse sistema, nào mais na posição de colônias.

Entretanto, ao mesmo tempo em que são postos em xeque pela internacionalizaçāo das decisōes da economia, esses países é que viabilizam esse mesmo processo, no sentido de que despressurizam contradiçóes internas dos países ricos, socializando as responsabilidades, os riscos e as perdas.

É característico desse paradigma, por exemplo, que a reprodução da força de trabalho seja responsabilidade da empresa apenas durante o tempo de trabalho direto. Para além dessa esfera, passa a ser responsabilidade do Estado, que tem que criar esquemas para a sustentaçāo da infância, da velhice, dos gastos com a aposentadoria e com a cobertura à doença. No paradigma da produção em massa, a manutençăo da saúde do trabalhador é atribuição do Estado, que pode, ele próprio, executá-la ou delegar a tarefa. De qualquer maneira, porém, ele distribui a responsabilidade pela manutenção da saúde do trabalhador em condiçōes compatíveis com as demandas do setor oligopolizado. Assim, o direito à saúde nāo abrange toda a populaçāo, mas apenas os empregados desse setor. $O$ mesmo ocorre em relaçāo a medidas que visam a prevenir ou a minorar impactos ocasionados por condições desumanas de trabalho, privilégio restrito a esse setor. Cabe ressaltar que a melhoria das condiçōes de trabalho restringe-se a ajudar o empregado ou dar-the cobertura para suportar a agressăo do dia-a-dia sobre seu corpo e sua mente. Nessa mesma linha, situa-se, também, a política de manter os salários em nível compativel com o consumo necessário à manutençāo da economia.

Quando se trata de Brasil, esse quadro revela-se ainda mais dramático e perverso. As políticas de habitação, saneamento, educaçāo e formaçāo profissional têmse limitado a compor um conjunto de atividades que o Estado, diretamente ou intermediando, assume para manter a força de trabalho em condiçōes de ser utilizada pelos setores oligopolizados da economia. Enquanto isso, grande massa da população encontra-se em situação calamitosa.

Outra característica do paradigma da produção em massa é o aumento dos lucros e a busca de 'superlucros' pela diminuição do custo de um dos fatores da produção, de maneira a manter o mesmo preço do mercado e obter um ganho adicional. Isso se conseguiu, por exemplo, instalando subsidiárias das grandes empresas multinacionais perto das fontes de matéria-prima e também através de mão-de-obra barata, tornando, assim, o preço do produto mais competitivo. Atualmente, esse 'superlucro' é obtido principalmente por meio da crescente incorporação de ciência e tecnologia ao processo produtivo, como forma de diminuir o custo de alguns fatores da produção.

A competitividade, nesse modelo, é baseada no baixo preço da unidade de um produto fabricado em larga escala. Uma de suas conseqüências é o fenômeno da terceirização da economia, ou seja, ampliação do setor terciário. Na própria empresa industrial, aumentam os setores de planejamento e de serviços, para dar 
cobertura à atividade de planejamento. Por outro lado, intensifica-se a urbanização e, em decorrência, a necessidade da criação de infra-estrutura urbana. $O$ próprio Estado tem que se modernizar e se racionalizar para cumprir as novas funções.

Nesse contexto, as relações entre capital e trabalho não podem mais se expor aos choques da fase concorrencial, não pode haver confronto direto porque isso perturba o fluxo da produção em massa, em que qualquer interrupção acarreta enormes prejuízos. É necessário ganhar, por antecipação, a boa vontade e a motivação da força de trabalho, sendo característico associar a produtividade à motivação do trabalhador. Para compensar a desqualificação, a desprofissionalização que a extrema divisão do trabalho acarreta, tenta-se criar um clima estimulante, que faça o trabalhador cooperar e ter vontade de participar, por meio de uma série de procedimentos persuasivos, de salários indiretos, de benefícios, relacionados ao aumento da produtividade. Um sintoma importante é a ênfase que a produção em massa dá ao treinamento gerencial e ao chamado desenvolvimento organizacional. O gerente, o administrador têm um papel importantíssimo na manutenção do nível de satisfação dos empregados, mesmo em condições adversas de execução do trabalho. Assim, a parte nobre do treinamento é direcionada para o corpo gerencial, que tem que ser coeso e 'comprar' o projeto da instituiçăo, seja uma empresa, um hospital ou uma entidade prestadora de serviços.

A educação e o trabalho, nesse modelo de produção em massa, tendem a um afastamento relativo, já que o sistema empresarial espera da escola apenas uma preparação básica. Interessa às empresas elas mesmas propiciarem o treinamento em serviço, já que, dessa forma, o trabalhador pode ser socializado dentro de uma cultura institucional específica.

Nos anos 60, esse modelo começa a entrar em crise, embora a maioria dos autores considere os anos 70 e 80 como o período de gestação de um novo paradigma. Enquanto a produção em massa tinha como pilares o preço baixo do petróleo e a mecanização barata, esse novo paradigma vai incorporar a microeletrônica para baratear seus custos. Do ponto de vista econômico, o esgotamento do paradigma da produção em massa decorre da dificuldade de continuar indefinidamente a divisăo do processo de trabalho de forma a eliminar os 'tempos mortos'. Por exemplo: a diminuição do tempo gasto por uma esteira para transportar certo equipamento tem limite, ou seja, acima de certo grau, não adianta aumentar a velocidade, porque aumenta o número de erros e de acidentes na linha de montagem, tornando economicamente impossivel compactar mais o trabalho.

Por outro lado, a produçăo em massa exige uma série de investimentos na aquisição e estocagem de matéria-prima, tendo-se que calcular corretamente a quantidade de cada material a ser comprado, para que a falta de um deles não inviabilize o processo produtivo. Tais fatores também representam limites econômicos para esse tipo de produção. Com a microeletrônica, foi possível inverter a lógica desse processo. A competitividade năo está mais associada à capacidade de produzir uma 
unidade barata para vender em grande quantidade, mas à de produzir exatamente 0 que o comprador deseja. Desse modo, ao invés de produzir primeiro para vender depois, produz-se o que já foi vendido. Com isso, pode-se evitar uma série de situaçöes, como a estocagem de matéria-prima e de mercadoria pronta, e reduzir o capital de giro e o investimento nas instalaçöes, assim como o tamanho das empresas.

O novo paradigma é compatível com a pequena empresa, que não precisa estar, necessariamente, vinculada a outras maiores. Neste novo modelo, ocorrem associações que acabam beneficiando o capital. Não mais se aumenta a planta da fábrica, mas criam-se pequenas empresas autônomas, embora do mesmo grupo, que prestam serviços à empresa maior. $O$ investimento desta se torna diferente, as proporções de capital fixo e variável também se modificam, facilitando a produção de itens específicos. Com isso, também se introduz um elemento considerável de controle da força de trabalho. Enquanto na produção em massa a organização dos trabalhadores é inevitável, pois, como resultado do nivelamento acarretado pela desqualificação, todos se igualam e se unem nas lutas comuns, nessa nova forma é possivel segmentar a organização dos trabahthadores, fazendo com que eles se voltem uns contra os outros. Os empregados da empresa maior são mais protegidos e têm bons salários, o que não acontece com os das outras, pequenas, que não possuem as mesmas regalias. Assim, estes passam a ver como seus grandes inimigos os colegas 'privilegiados', e não os patrōes.

É interessante observar como esse novo modelo permite, de certa forma, outros tipos de manipulação. A organização dos trabalhadores, que, no modelo de produção em massa, pode ter muita força, nesse outro torna-se mais delicada, por uma série de razōes. Se o primeiro já se caracterizava por ser um modelo excludente, o paradigma que surge é ainda mais. Alguns autores calculam que, no final do século, apenas um quarto da população economicamente ativa estará bem empregada e um quarto estará semi-empregada, enquanto a metade ficará fora da economia. Outros falam numa volta à manufatura, com grande parte da população permanecendo à margem da economia organizada, que manipula e reproduz o capital.

Por outro lado, afirma-se que o novo paradigma técnico-econômico não está ainda definido, existindo três opçōes, cuja escolha, em última instância, se pautará por critérios políticos. Uma delas - só compativel com o Terceiro Mundo - seria a intensificação do modelo fordista, cuja sobrevida seria possivel à custa, por exemplo, de achatamento salarial. Outra seria modificar esse modelo, mantidas, porém suas linhas gerais em benefício de algumas esferas não atendidas do mercado, tais como aquelas ligadas às novas tecnologias, em que se inclui a própria microeletrônica. $A$ terceira seria o abandono radical do paradigma fordista em favor da chamada flexibilização do trabalho, modelo baseado em pequenos grupos autônomos, de pessoal altamente qualificado, em que a máquina se coloca como um complemento do homem, tendo realmente sua produtividade aumentada pela criatividade humana. Isso leva aos conceitos de requalificação, reprofissionalização e politecnia, no 
sentido de que esses processos seräo extremamente importantes somente para aquela parcela dos trabalhadores protegidos.

Nesse contexto, as relações entre educação e trabalho revestem-se de novos significados. A função da educação se torna mais importante na preparação da força de trabalho, uma vez que as habilidades requeridas do novo trabalhador são muito relacionadas com aquelas desenvolvidas na escola, isto é, responsabilidade, capacidade de abstração, de resolver problemas, de trabalhar com símbolos e compreensão de textos abstratos, entre outras. Surgem também as idéias da educação do consumidor e da consciência ecológica, pois tanto a produção quanto o consumo podem ocasionar a destruição do planeta.

Parece que, em termos de qualificação, o que deve acontecer é um aumento do que se chama polarização da qualificação, isto é, um aumento do número absoluto de pessoas altamente qualificadas $\mathbf{e}$, simultaneamente, um aumento na quantidade de pessoas que perdem em matéria de qualificação.

Abro um parêntese para chamar a atenção para as questōes da biotecnologia e da microeletrônica, que, seguramente, vão ocasionar mudanças significativas no perfil da qualificação do profissional da saúde em todos os niveis. Nesse contexto, o técnico de segundo grau aparece como um elemento muito importante, como membro das equipes de pesquisa e desenvolvimento, como operador de equipamentos mais sofisticados em hospitais e no atendimento direto à população, bem como no estabelecimento de estratégias de saneamento e de combate a pragas.

Quando se pensa esse novo modelo em termos de Brasil, vê-se que o fato de a oligopolização ter precedido a abertura da economia trouxe contrastes muito maiores do que os existentes no Primeiro Mundo. Avalia-se que o País possui um parque industrial de base bastante ampla, bastante equilibrado e diversificado nas áreas tradicionais, mas extremamente deficitário no que diz respeito às chamadas tecnologias de ponta, que, inclusive, são os pontos frágeis da integração horizontal e vertical desse parque. De qualquer maneira, o tipo de industrialização ocorrida, embora propicie ao País menos condiçōes para competir no mercado internacional, fornece melhores condiçóes de recuperação. Ou seja: considerando-se seu grande mercado interno, essa base mais larga e diversificada permite pensar em obter autonomia industrial e sanar as falhas a partir da decisão política de enfrentar o problema.

No caso do Brasil, é importante notar que o modelo fordista da produção em massa nem chega a se consolidar. Na verdade, já no fim do chamado 'milagre econômico', esse processo praticamente aborta, tendo o Estado decidido assumir a realização de grandes obras para manter as taxas de crescimento e a consolidação do modelo de produção em massa, iniciativa também fracassada.

Concomitantemente a esse processo, começam a surgir indústrias baseadas no novo paradigma. Assim, além da heterogeneidade que já se observa nos países do Primeiro Mundo, em que a microeletrônica não avança uniformemente, aqui 
ainda existe essa outra heterogeneidade mais alarmante, ou seja, a convivência da tecnologia de ponta com a miséria absoluta, quadro que suscita importantes questões.

A reorganizaçāo da estrutura ocupacional no Brasil se caracteriza pelo crescimento do setor terciário, pela ampliação das funçōes do Estado e das grandes empresas, incluindo o crescimento do setor produtivo estatal e um primeiro momento de democratizaçāo, no sentido weberiano de racionalização da máquina governamental. O Estado, na verdade, serve de mediador para viabilizar a abertura da economia ao capital internacional, com o objetivo de preservar as condiçỏes de funcionamento dos oligopólios. Na agricultura, acontece o que se chama de modernizaçāo conservadora, baseada na criaçăo de agroindústrias, de grandes propriedades, de privilégios, de proteção ao grande proprietário. Por outro lado, as pequenas propriedades, embora sejam as responsáveis pela maior parte da produçāo (inclusive para exportação) têm menos acesso ao crédito, são menos protegidas.

Pode-se assinalar também o surgimento de um setor quaternário no País, com base em critérios que não estāo voltados para o bem-estar da população, mas, sim, para a sustentaçăo do modelo de crescimento econômico. O bem-estar da populaçāo constitui apenas um subproduto, e em momento algum desse crescimento é tratado como objetivo principal.

Por outro lado, o controle da força de trabalho por meios persuasivos é muito importante na década de 70 , perpassando toda a reforma de ensino que começa em 1968 e acaba em 1972. A própria criação do sistema nacional de formação de măo-de-obra e do incentivo fiscal à formação profissional (Lei 6.297/75) constitui un mecanismo que, de um modo ou de outro, viabiliza formas de controle social da força de trabalho por meios persuasivos, quer dando aos trabalhadores uma socialização prévia, quer propiciando às empresas condições de elas próprias socializarem seus empregados, dentro de uma cultura institucional específica.

De certa forma, essas iniciativas representam uma contramedida ao processo de sindicalizaçāo maciça no País observado na década de 70 , como resultado da própria política econômica. Realmente, é impossível oligopolizar a economia sem que os trabalhadores se articulem, porque māo-de-obra pronta para ser utilizada implica certa organização. E ela aconteceu no Brasil, nos anos 70 , quando quase dobrou o número de sindicalizados urbanos, e surgiu um novo tipo de sindicalismo com características diferentes das do tradicional 'peleguismo'. A esses fenômenos veio juntar-se a sindicalização maciça dos trabalhadores do campo, dos profissionais liberais e dos funcionários públicos.

Esse movimento teve, além dos mecanismos estatais de controle social da força de trabalho, uma contrapartida na instituição do lobby por parte das organizações patronais. Nesse espaço, o conhecimento das bases técnicas do processo de trabalho adquire maior importância como elemento de negociação. Numa situação em que a luta entre capital e trabalho passa a ser mediada pelas organizaçöes via mesa de negociação, o conhecimento das bases e das condiçóes em que o trabalho 
é produzido assume fundamental importância. Para o profissional dos níveis médio e elementar da área da saúde, é prejudicial não estar organizado e não ser qualificado, porque, dessa forma, ele não consegue contra-argumentar em relação à sua exploração, como mão-de-obra barata, pelas empresas prestadoras de serviços.

Nessas circunstâncias, é necessário distinguir dois pontos de vista em relação às funções sociais da educação básica. Primeiro, o ponto de vista do País. Se há uma vontade política de mudar a situação do Brasil na divisão internacional do trabalho, é preciso enfrentar a questão do novo paradigma. Algumas teorias dão certa vantagem aos países que, como o Brasil, abortaram o processo de produção em massa, porque eles não têm capacidade instalada ociosa para sucatear e perder. Ou seja: não tendo sido muito grande a inversão e havendo condiçōes de trabalhar com menor capital fixo, talvez seja possível queimar etapas. A educação básica, em particular a de nível médio, por causa da idade do aluno e das condiçōes em que ele tem de sistematizar o conhecimento, é de fundamental importância para criar as bases da produção endógena e de conhecimentos científicos e tecnológicos, da aplicação e da administração da política de ciência e tecnologia no País. Desse modo, é importante repensar o sistema de educação básica, especialmente no caso do técnico de segundo grau.

O segundo ponto de vista é o da população: o que é bom para o Brasil é bom também para todos os cidadãos brasileiros? Numa sociedade socialista talvez a resposta fosse positiva. Mas, numa sociedade de classes, o fato de ser importante para o País mudar a participação na divisão internacional do trabalho não significa que seja igualmente benéfico para todas as pessoas. Essa mudança pode mesmo ser uma forma de atender os interesses da classe dominante, e não da maioria dos trabalhadores. Por isso, é necessário distinguir duas perspectivas.

Para a classe dominante, resolver o problema das novas tecnologias talvez não seja tão decisivo quanto para os trabalhadores, porque, de certa forma, ela é conservadora no sentido de que, se o Brasil permanecer subdesenvolvido, continuará viável insistir com o paradigma fordista. Essa, provavelmente, seria a saída para as elites, mas não para os trabalhadores, aos quais necessariamente interessa o desenvolvimento das forças produtivas. Portanto, é importante notar a existência de contradiçōes que possibilitam espaço de manobra, que pode ser usado em benefício do trabalhador, desde que haja clareza na concepção da escola que se pretende, do técnico que se quer.

No momento, urge investir na formação do técnico nas áreas de saúde, educação, saneamento e em outras de interesse claramente coletivo. Não é tanto o caso do técnico industrial, pois a própria empresa encontrará mecanismos de qualificar esse tipo de profissional para sua demanda. É o técnico de interesse coletivo que deve merecer maior atenção dos especialistas e dos administradores da educação.

Há várias indagações ainda a serem respondidas. Mesmo que a escola fundamental seja unitária, como pensar o ensino técnico profissional, sabendo-se que 
grande parte da população está no mercado informal e que, à medida que o novo paradigma econômico for sendo incorporado à economia brasileira, essa parcela da população continuará excluída? Como pensar a habilitação técnica, considerando o setor informal ou o empregado nos oligopólios tradicionais que estão em crise, como a siderurgia, por exemplo? E para o setor chamado 'de ponta', qual seria o perfil desse técnico? As habilitações que existem hoje, baseadas nas disciplinas tradicionais, resolvem o problema? Qual o conhecimento necessário a um técnico em biotecnologia?

Os limites entre as áreas tradicionais do conhecimento estão cada vez menos distintos, o mesmo ocorrendo entre os setores da economia. $\mathrm{Na}$ agroindústria, estāo-se unindo os setores terciário e primário, ou seja, os próprios setores tradicionais da economia estão tornando mais tênues os seus limites. $́$ urgente pensar como deve ser a formação do técnico numa situação de transição e de mudanças tão significativas. 



\section{PROFISSIONALIZAÇÃO DE TRABALHADORES DE SAÚDE DE NÍVEL MÉDIO: PROBLEMAS E DESAFIOS}

Alina Maria de Almeida Souza

A formação de pessoal de nivel técnico apresenta alguns problemas que extrapolam as preocupações debatidas atualmente, como, por exemplo, a necessidade de integração entre ensino e serviço. As questōes vinculadas ao processo educativo, tema desta exposição, suscitam algumas outras, que consideramos importantes diante do projeto de Reforma Sanitária e da conjuntura nacional.

Observamos avanços importantes do ponto de vista político-jurídico para a instituição do Sistema Único de Saúde de acordo com as diretivas constitucionais, incluindo a formação de recursos humanos. A prerrogativa do setor saúde de ordenar essa formação acarreta uma série de conflitos, cuja resolução requer discussão e aprofundamento, principalmente com relação aos problemas educacionais, em especial no âmbito da universidade. Como equacioná-la com a proposta de autonomia universitária? Alguns setores da sociedade civil argumentam que o setor saúde não deve se envolver com educação, pois esta deveria ser uma atribuição exclusiva do setor educaçăo. A corporação universitária defende também este ponto de vista.

A tramitação da Lei de Diretrizes e Bases da Educação (LDB) no Congresso Nacional tem sido historicamente demorada em função da divergência de interesses dos vários setores ligados às instituições educacionais públicas e privadas, e também da relativa falta de organização do movimento social.

Além disso, as propostas contidas na LDB tratam a formação técnica como complementar à educaçāo básica, ou seja, uma área a ser construída após a conclusão do primeiro e segundo graus. Portanto, a profissionalização inclui-se no projeto como tarefa posterior ao processo de educação geral de formaçăo do cidadão.

Se consideramos que, no setor saúde, as forças organizativas têm sido mais ativas, e o projeto da saúde tem avançado mais rapidamente no campo políticojurídico a partir da Constituição, podemos concluir que as divergências entre projetos de preparação de técnicos para a área da saúde estarão presentes por algum tempo. Além disso, deve-se reconhecer que há situações problemáticas e heterogêneas quanto à força de trabalho no setor saúde, pois quase cinqüenta 
por cento da força de trabalho empregada não possui qualquer qualificação específica e exerce na prática direcionalidades técnicas.

Dessa forma, há uma contradição tanto do ponto de vista dos projetos educacionais, como do movimento da Reforma Sanitária, que, basicamente, se constrói no ideário da universalidade, eqüidade e integralizaçăo de açōes e que, necessariamente, pressupōe assistência à saúde de qualidade. Esse pressuposto, por sua vez, implica a formação adequada de todos os trabalhadores do setor saúde, universitários ou nāo, para que se possam alcançar os objetivos da Reforma.

Também é necessário pensar, prospectivamente, na renovação dos quadros $\mathrm{e}$ na ampliação da oferta de profissionais devidamente preparados. Dessa forma, a profissionalizaçăo na área da saúde deve avançar em duas direçōes: qualificar os trabalhadores e formar novas geraçōes de técnicos para ingressar no setor.

Do ponto de vista educacional, esse panorama apresenta alguns problemas. As escolas técnicas na área da saúde devem buscar metodologias para profissionalizar trabalhadores que foram marginalizados do processo educacional regular ao longo dos anos, muitos sem qualquer grau de escolaridade. Ao mesmo tempo, necessita desenvolver processos metodológicos para o contingente de jovens oriundos da escola regular, que podem iniciar seu processo de profissionalização antes de integrar-se à força de trabalho.

A busca de metodologias adequadas a essa situação deve conduzir o pensamento educacional para a profissionalização no setor saúde. A construção de um processo educativo para qualificar os trabalhadores já engajados na força de trabalho precisa ser necessariamente diferente daquela que se destina à profissionalização de leigos. Essa busca de metodologias suscita também questōes relativas à própria compreensão do processo de Reforma Sanitária.

A Reforma Sanitária, neste momento de processo eleitoral para a escolha de um novo presidente da República, pode vir a ser comprometida pelo entendimento de seu significado. O Brasil, como afirmam vários analistas políticos, não está elegendo apenas um novo presidente, mas uma opçāo no campo do neoliberalismo ou do socialismo. ${ }^{1}$ Essa opção terá repercussões no campo da saúde e do movimento da Reforma Sanitária. Existe a possibilidade de direcionar a implantação do SUS para atender apenas aos grupos marginalizados, ou seja, torná-lo um projeto de saúde para os pobres, cidadāos considerados de segunda categoria, e não para toda a população. Diante dessa alternativa, vai-se pensar na escola profissionalizante de saúde para preparar técnicos que cuidem da população de baixa renda ou, na perspectiva da universalização, preparar profissionais orientados para um patamar de cidadania mais avançado, ou seja, todos os brasileiros, independentemente da condição econômica e social, tendo seus direitos à saúde respei-

1 A autora faz referência ao processo eleitoral em que Fernando Collor se elegeu presidente (Nota dos Orgs.). 
tados e atendidos. Este momento, portanto, nos coloca frente a duas direçōes opostas na concepção de formação de pessoal técnico e constitui um desafio para a definiçăo de políticas de formação desse contingente.

Diante de nossa história de luta no movimento da Reforma Sanitária, cabe a interrogação: seremos os executores dessa política, formaremos um bloco de protesto ou teremos de nos aliar para ajudar a avançar e a manter o ideário constitutivo da Reforma? Frente à incógnita das eleiçōes e diante destas perspectivas, só nos resta ficar atentos e acompanhar os resultados.

Passaremos agora a examinar problemas inerentes aos processos de preparaçāo de pessoal de saúde, os fatores hoje presentes e suas tendências. Inicialmente, é necessário enfatizar que a área de recursos humanos vivencia uma contradiçăo: em termos de discurso é extremamente valorizada, mas na prática é pouco dignificada e tratada sem prioridade política. O corpo de conhecimentos da área é quase sempre relegado a um segundo plano, os problemas equacionados na base do 'eu acho', do 'jeitinho para tratar com pessoas' etc. É preciso, portanto, buscar caminhos para valorizar o setor. Estudos existem, houve avanço no conhecimento da força de trabalho, do processo de trabalho na saúde, da organizaçăo dos serviços, das profissōes, suas histórias e movimentos corporativos. Alguns trabalhos teóricos relevantes sobre a área vêm sendo apresentados e discutidos.

Verifica-se que uma ênfase maior tem sido dada aos assuntos referentes à administraçăo de pessoal. Por exemplo: as propostas da área de recursos humanos para a Constituição e a lei do SUS foram todas resumidas, enfatizando-se especificamente questōes dos planos de cargos e carreiras. O ordenamento da formaçăo de recursos humanos fica definido de forma ampla, sem especificar o papel do setor saúde na condução do processo de formaçăo de seu pessoal, principalmente de nível médio. Historicamente, a área da saúde vem preparando o pessoal auxiliar e técnico, sendo a experiência no setor educação, nesse campo, bastante limitada e de resultados pouco significativos, seja na quantidade, seja na qualidade. Pode-se afirmar, com segurança, que a maioria dos técnicos têm sido preparados, formal ou informalmente, pelo setor saúde. A área de enfermagem, em que a formaçâo da maioria dos auxiliares e técnicos é realizada por esse setor, comprova esse fato.

O papel do Ministério de Educação tem sido, basicamente, o de normatizar currículos mínimos profissionalizantes, nem sempre pautados por uma visão de recortes do conhecimento em função do processo de trabalho, mas por uma miniatura de currículos do nível superior, como no caso da enfermagem. É necessário analisar esses currículos e legitimar as habilitaçōes específicas da área da saúde, buscando visualizar o perfil do novo profissional para o SUS de acordo com as bandeiras de luta do movimento da Reforma Sanitária e das diretrizes estabelecidas na VIII Conferência Nacional de Saúde. Na formação desse profis- 
sional, deveremos, principalmente, buscar superar as dicotomias coletivo versus individual e teoria versus prática.

É fundamental refletir sobre como organizar um processo pedagógico que atenda essas questões. Torna-se imperativo conhecer o processo de trabalho de forma prospectiva, ou seja, aquele que esperamos vir a ocorrer com a reorganização do sistema, no sentido de sua maior produtividade e resolutividade. Precisa-se construir um currículo que reflita a integralidade das açöes de saúde e que, no campo de ensino de pessoal técnico e auxiliar, supere a dissociação entre teoria e prática. Trata-se de buscar um processo pedagógico que integre a formação profissional, a educação geral e o sentido de cidadania.

Esses são problemas cruciais no desenvolvimento de uma escola técnica para o setor saúde. Uma escola que recupere e legitime os que já estâo trabalhando sem preparação específica e que forme novos profissionais para o mercado. Em resumo, as questōes que se apresentam são: que novos perfis profissionais são esses? Qual será o processo de trabalho no SUS? Quais os aspectos coletivos desse processo, as relações interpessoais, quais as especificidades e direcionalidades técnicas? Assim, será possível definir cortes no conhecimento para fundamentar procedimentos e ações e, ao mesmo tempo, compor novas habilitações específicas para a área da saúde.

Essas são apenas especulações, pois a nossa realidade ainda apresenta uma necessidade primordial de superação em termos de quantidade. A área de enfermagem, por exemplo, representa aproximadamente $49 \%$ da força de trabalho, dos quais cerca de $60 \%$ não têm preparação específica. Devemos considerar imperativa a definição dessa área como prioridade política no desenvolvimento de esforços de formação, para superar a atual bipolarização na qualificação da força de trabalho (médicos versus trabalhadores sem qualificaçăo) e suas conseqüências nos processos institucionais de atenção à saúde. A partir dessa realidade, nos defrontamos com o desafio da metodologia para a integração ensino/serviço, ensino/trabalho e a legitimação do processo.

Os elementos da metodologia a serem examinados são o sujeito, o objeto (conteúdo) e o processo resultante dessa interação - o conhecimento -, para que a aprendizagem resulte da integração com a realidade. Do ponto de vista da cognição, temos que fazer uma opção clara de entendimento do sujeito. No caso dos trabalhadores de saúde ou postulantes de profissōes de saúde, sabemos tratar-se de adultos ou jovens, cidadãos com uma história sociocultural específica e com capacidade de promover transformações e desenvolver conhecimentos. Estamos diante de um grupo heterogêneo com relação não apenas à experiência no campo da saúde, mas também às visōes de mundo e à faixa etária, amplitude essa que não permite um equacionamento metodológico único, enfocado nas características do sujeito.

Com relação ao objeto, devemos considerar sua complexidade. A área da saúde deve ser entendida como um campo essencialmente multidisciplinar, em que 
as ciências biológicas, físicas e sociais interagem de forma singular na construção do objeto. A sua definição requer a compreensão da totalidade, e seu corte deve corresponder às necessidades do processo de trabalho, de modo que o conhecimento do objeto fundamente a prática concreta.

Uma vez equacionadas as questões relativas ao sujeito e ao objeto de conhecimento (conteúdo), cabe, na busca da metodologia, encontrar um caminho que possibilite ao sujeito interagir com o objeto de várias formas no plano da realidade, a partir de sua própria concepção de mundo. Em outras palavras, a metodologia deve definir uma série de atividades que coloquem o sujeito frente ao objeto, de modo que ele possa dominá-lo a partir de sua experiência e vivência e, nesse processo interativo, permitir que o mesmo não seja apenas especializado ou qualificado tecnicamente, mas transformado em agente ativo, sujeito crítico no processo de trabalho.

Diante dessas questōes, podemos considerar que a Escola Técnica de Saúde tem um desafio muito grande. Por um lado, ao definir uma metodologia para trabalhadores, deve considerar toda a prática específica acumulada e a necessidade de sua revisão. Por outro, para os que estão postulando a área sem experiência anterior, as aproximaçōes da realidade podem passar por vivências simuladas, como passo intermediário para a inserção no concreto das práticas de saúde.

Além disso, a escola profissionalizante de saúde que se proponha preparar pessoal de várias áreas técnicas deverá pensar nos aspectos coletivos do conhecimento para todos os trabalhadores da saúde, de modo a consubstanciar o ensino da cooperação e o sentido de equipe de trabalho nas especificidades de cada uma dessas áreas. Deve-se pensar que uma escola técnica pode desenvolver profissionais com um perfil que atenda às prioridades dos programas de saúde em termos de quantidade e qualidade, considerando a possibilidade de adaptar esse perfil à demanda local, regional e até nacional. É importante enfatizar que a escola técnica, para enfrentar os desafios da atualidade, não deverá, de nenhuma forma, pensar em polivalência para o pessoal da saúde, mas perseguir a formação especializada de acordo com direcionalidades técnicas específicas, dentro de um espírito de entendimento e cooperação de equipe de saúde. 



\section{DEBATE}

Maria Umbelina discute a formação profissional no campo da saúde, chamando a atenção para a crise dos paradigmas de regulação do processo de trabalho. Mostra que essa crise tem uma faceta no Primeiro Mundo, onde o processo de concentração do capital levou séculos, e que, nos países do Terceiro Mundo, isso acontece em poucas décadas, resultando em processo marcadamente violento. Aponta algumas contradições nessa crise dos paradigmas, entendendo que a definição dessas contradições é de caráter político. Conclui chamando a atenção para a formação básica e sua importância para a cidadania.

Alina Souza enfatiza também a necessidade de termos uma opção política que dê conta dessa realidade. Toma como ponto de partida a luta travada pelos profissionais que têm uma perspectiva de saúde pública que aponta para uma nova reordenação da sociedade e um novo tipo de homem. É preciso também levar em conta que essa luta se situa num contexto onde há um sistema único de saúde enquanto projeto e uma prática privatista brutal. Nessa nova perspectiva, como atender àqueles já inseridos no processo de trabalho em saúde (que ela sintetiza como ensino no trabalho), os que ainda não estão nesse processo e os que precisam ter essa mentalidade renovada?

Acrescento outro problema, tentando resgatar essa concepção mais ampla de saúde e de cidadania: quem garante que a formação básica, entendida como aquela que dá conta do entendimento das bases científicas, tecnológicas, não é profissionalizante?

Temos que pensar uma escola básica que, na sua concepção ampla, forneça elementos de profissionalização. Mas isso não resolve o recorte específico. A questão nos leva a refletir sobre como delimitar um campo sem restringi-lo demais. É preciso entender e 'desenhar' uma escola básica que tenha elementos de profissionalização, mantendo interfaces com a dimensão mais ampla de cidadania. Isso pode trazer luzes para pensar em que momento trabalhar a formação profissional mais específica, mo- 
mento que não é definido a priori, mas considerando as circunstâncias mais propícias para que ele ocorra.

Alina Souza chama a atenção para a complexidade do processo de formação dos profissionais, que, em última instância, serão os atores da concretização da Reforma Sanitária. A aproximação entre educação e saúde acaba acontecendo muito mais por justaposição desses dois setores do que em virtude de uma reflexão a respeito das estruturas educacional e de saúde e de como se elas se articulam. É freqüente encontrar na saúde a tentativa de suprir deficiências da formação do profissional recémingressado na rede por meio do próprio serviço de saúde, assumindo o compromisso (e se incumbindo) de responder pela qualificação desse trabalhador. Isso traz alguns problemas, porque há limites na possibilidade de atuação da área da saúde e, mais especificamente, do serviço. É uma questão nuclear para quem pensa não a educação pela educação, nem a saúde pela saúde. Maria Umbelina, quando discorre sobre a modificação dos paradigmas, traz um componente importante para essa reflexão, onde se inclui o tema do mercado profissional como definidor das habilitaçōes necessárias para formar o profissional $x$, y ou $z$.

É importante indagar como acontece a articulação da proposta de formaçāo profissional com o mercado de trabalho. Se a articulação é direta e uma vez modificado o paradigma, algumas coisas têm que ser repensadas, incluindo as cento e tantas habilitações profissionais existentes, das quais vinte e poucas da área da saúde. Tem-se que manter todas elas, acrescentar outras ou suprimir algumas? A discussão da habilitação profissional no segundo grau é fundamental, nuclear, no sentido de definir por onde caminhar. Alina Souza aborda o problema das escolas técnicas e desenha uma proposta para elas. Mas o que se está entendendo realmente por escola técnica para a saúde? Como a discussão está articulada com o pensar as especificidades de uma formação em nivel de segundo grau? E essa formação se insere na formação básica ou, prioritariamente, tem que se pensar a criação dessas escolas a partir das necessidades do setor saúde?

\section{Maria Umbelina}

A formação básica, nesse momento, tem que estar necessariamente articulada com a questão do trabalho. A idéia de uma educação separada do trabalho é obsoleta, em face das atuais transformações sociais.

Considerando a situação quer do País, quer dos trabalhadores, é importante que o segundo grau tenha condiçōes de 'abrir' para o aluno a compreensão de como se organiza o trabalho, o que é produção, que tipo de relaçōes são geradas a partir daí. É fundamental que o aluno tenha esse conhecimento, tenha condições de 
perceber de que forma se abrem ou se fecham instâncias de participação política, que relação essa participação política tem com a organização do trabalho, como o conhecimento da organização do trabalho é instrumento da participação política, é argumentação, é força do trabalhador em termos de participação política. Que ele tenha acesso, inclusive, à produção no campo das humanidades, das artes, que também fazem parte da produçăo da existência dele. São outras facetas relacionadas com essa totalidade da vida econômica, da vida política e da vida cultural.

É nesse sentido que entendo o segundo grau, com essa faceta de relação com o trabalho. Năo sei se seria profissionalização stricto sensu, mas, de qualquer maneira, significaria preparar a pessoa para viver na sociedade contemporânea. Na perspectiva desse novo paradigma, que não está ainda totaimente definido, pode-se ver claramente que a atuação de outro conjunto de princípios da organização do processo de trabalho em nossa sociedade de Terceiro Mundo ocasionará um contraste muito mais violento do que nos países do chamado Primeiro Mundo. Nesse prisma, o próprio exercício da cidadania, da participação política, a vida do cidadāo, enfim, fica muito condicionada por um conhecimento que se aproxima não apenas de uma profissionalização, mas do conhecimento bastante profundo de alguns aspectos do trabalho.

Isso pode ser observado, por exemplo, na questão epidemiológica, na importância de esquemas de vacinaçăo em massa e no movimento de defesa do consumidor quanto ao uso de defensivos agrícolas e outras drogas. É preciso ter alguma malícia em relação às derivaçôes das tecnologias, de forma mais contundente, de modo a năo se expor enquanto pessoa a riscos desnecessários e, também, a poder interferir, de forma qualificada, na tomada de decisões quanto ao uso de tecnologias que vão afetar a vida de cada um. Há uma interface muito grande entre esse ensino técnico e o segundo grau, considerado como educaçāo básica. Nas circunstâncias atuais, em grande parte, a bagagem do cidadāo comum deve conter os elementos necessários à profissionalização. É claro que a parte operacional do ensino técnico não será possível. Não tem cabimento formar todas as pessoas como técnicos em determinado campo. Essa reflexão sobre a educação básica voltada para o trabalho avança um pouco quando se discute, por exemplo, se a formação profissional deve ocorrer durante ou após o básico. Entendo que o ensino técnico deveria privilegiar, como função da educação pública, a formação de técnicos nas áreas de interesse coletivo, como saúde, educação e saneamento.

\section{Alina Souza}

No Brasil, dado seu quadro de carencias, ainda poderia haver muita festa para quem terminasse a quarta ou a oitava séries do primeiro grau. Na Europa e nos 
Estados Unidos, na época em que somente a metade da população conclúía o equivalente ao quarto ano, havia uma festa de família e missa, assinalando a conclusão de um ciclo.

Dadas as condições atuais do País, uma escola técnica para a área de saúde tem que, pelo menos, resgatar o social para os trabalhadores, para aquelas pessoas que foram marginalizadas do sistema educacional, até que seja possivel estabelecer níveis. Cuba, num determinado momento da revolução, fez um projeto político visando a atingir determinado patamar, que está mudando neste momento. $O$ país vem alterando, inclusive, a política e as exigências para a formação de enfermeiros.

Temos que pensar uma escola técnica para este Brasil tão conflituoso e contraditório, que tem patamares variados em funçāo de diferenças regionais. Essa escola técnica de saúde deve acolher essa discussão, bem como problemas mais diretamente ligados à área educacional, para poder profissionalizar, porque, em última instância, são pessoas que compõem a chamada população adulta, a população proclutiva.

Não penso na escola básica de 'cuspe e giz', mas, sim, na perspectiva de uma pessoa que faz a seguinte pergunta: "Se passarmos da química aristotélica para a química do raio laser, qual a mudança qualitativa para a sociedade?". Quando defendemos a escola básica ligada ao trabalho, não a ligação imediata, mas mediada, imaginamos um curso de química que, de modo gradativo, dê conta dos avanços da ciência química, mas que, ao mesmo tempo, forneça elementos consistentes ao individuo para que ele possa fazer o recorte, possibilitando-lhe, por exemplo, optar por ser técnico em saúde, e não técnico em transporte.

Parece-me que a tese defendida hoje seria a de garantir, de defender, a escola básica profissionalizante em todos os campos de uma sociedade democrática que aponte para uma sociedade socialista. Porém, como dar conta da realidade rebelde que ai está, o que fazer? A posição politicamente mais adequada seria que a profissionalizaçāo stricto sensu fosse concomitante a essa escola básica de primeiro c segundo graus. Hoje, o individuo passa quatro ou cinco horas por dia na escola e complementa sua formação em outra instituição. Sonhando um homem novo numa sociedade nova, uma educaçāo desinteressada, no sentido de não estar subordinada às imposiçōes do mercado, poderia ser pensada uma escola básica na qual o individuo tivesse um bom ensino de quimica, de física, de história, discutisse o processo de trabalho $c$, articuladamente, fosse se profissionalizando em outra entidade. Isso idealmente, pois estamos sonhando um homem novo numa sociedade nova.

Quando se afirma que o cnsino básico qualifica, profissionaliza, isto significa que esse básico deve dar conta dos vários campos, das ciências naturais, das ciências biológicas, das ciências físicas, das ciências químicas, das ciências sociais, da cultura, 
dos valores. Precisa também buscar um núcleo que organize o conhecimento em determinado campo. Isso é profundamente profissionalizante.

\section{Maria Umbelina}

O ensino técnico stricto sensu deve ter, obrigatoriamente, um compromisso com o exercício da profissão, porque é um processo mais sistematizado, em que se investe numa pessoa que já é privilegiada porque conseguiu atingir determinado grau de escolarização. Por outro lado, diante da tendência ao desemprego estrutural de metade da população, são da maior importância formas alternativas de profissionalizaçăo, especialmente para o indivíduo que atua na economia informal. A esperança seria que o desenvolvimento criasse condiçōes de tirar esse cidadão da economia informal, mas o que está surgindo é o contrário, o novo paradigma tende a acentuar essa marginalização.

Imagino como poderia ocorrer, na prática, a profissionalização dentro da educação geral. Entendo que, a médio e longo prazos, isso acarretaria uma mudança da sociedade. Seria também interessante saber como tem sido essa experiência no Projeto Larga Escala.

\section{Maria Umbelina}

Essa é uma questão extremamente complexa. Considero fundamental a perspectiva apontada como uma saída a curto prazo, não só melhorando a qualidade do ensino básico, mas tornando-o profissionalizante, no sentido mediador e não imediato, embora a abertura dessa perspectiva possa ser perigosa se não for estabelecida uma referência prévia. A marginalização, o não estar no processo produtivo é uma situação muito complexa, se aliada à fluidez das profissōes, que são temporárias e provisórias. Parece-me que a dificuldade é saber a referência que isso coloca, porque, caso contrário, a medida a ser adotada pode ser também fragmentária e, se falhar, poderá ficar associada ao que hoje acontece na chamada escola básica e na profissionalização.

Não há um eixo pelo qual se consiga, minimamente, dar coerência a uma articulação em benefício do próprio trabalhador, uma vez que ele pode até confundir o processo tecnológico como seu inimigo. Só se supera esse problema com uma compreensão distinta da atual sobre o avanço no setor produtivo que interesse, fundamentalmente, à classe trabalhadora e, se não contempla esse interesse, como o processo educacional pode acompanhar isso não de maneira imediata, mas na 
compreensão do próprio interesse e ponto de vista individual e coletivo dessa classe trabalhadora. O desafio está em pensar nas múltiplas formas diferenciadas (incluindo o ensino regular) que considerem a formação geral e a formação específica no espaço físico e temporal da unidade de serviço, e até nas formas de resolver, a curto prazo, determinadas demandas que as políticas públicas possam vir a exigir ou estejam exigindo em nível de qualificação profissional. A decisão, porém, deve contemplar um projeto contra-hegemônico, com o profissional não sendo visto como um simples recurso descartável. Não se pode pensar em pessoas enquanto simples recursos humanos, pelo menos no processo educacional, porque recurso se descarta. Se a máquina fica obsoleta e a substituo por outra, a tendência é utilizar essa nomenclatura e entender recursos humanos da mesma forma. Aquele profissional ficou velho, desgastado, năo interessa mais, chamo outro. Não vejo como dissociar forma de conteúdo, nomenclatura de essência.

\section{Alina Souza}

Em relaçăo ao Projeto Larga Escala, ${ }^{1}$ uma questáo deve ser compreendida: a profissionalização necessariamente nāo descarta a educação geral. A grande importância desse projeto é a tentativa de fazer cortes de conhecimento no currículo das habilitaçōes mediante um processo metodológico que parte da representação do real, de como se deseja trabalhar determinado conceito, para então caminhar no sentido de atingir esse mesmo conceito, mais elaborado e até científico, do ponto de vista da saúde. O aluno percorre uma trajetória diferente da que se conhece na escola regular, o que permite adicionar elementos, ainda que formalmente não oferecidos, da educação geral como, por exemplo, o português, com o objetivo de melhorar a redação.

Algumas habilitações do Projeto Larga Escala, que não se construíram no que se chama currículo integrado, mas utilizando o currículo tradicional, têm um certo tipo de deficiência: a questão da legitimação é absorvida, melhora a qualificação, porém não há um rigor tão grande sobre a qualidade, como ocorre num currículo que integra o conhecimento horizontal e verticalmente. Essa integração não se dá por disciplinas, mas por um enfoque que possibilite chegar a conceitos como o de

1 O "Programa de Formação em Larga Escala de Pessoal de Nível Médio e Elementar para os Serviços Básicos de Saúde", mais conhecido como "Projeto Larga Escala", foi concebido em 1981, resultado de parceria interinstitucional entre os Ministérios da Saúde, da Educação e Cultura e da Previdência e Assistência Social, com o apoio da Organizaçāo Pan-Americana de Saúde. A estratégia formulada pelo "Larga Escala" desenvolve-se no sentido de integrar o setor saúde com o da educaçāo, possibilitando uma formaçāo em serviço com reconhecimento legal. A partir do movimento de Reforma Sanitária, o Projeto ganhou impulso para sua institucionalizaçāo, com a criaçăo de Centros Formadores/Escolas Técnicas de Saúde, reconhecidos pelo sistema educacional e vinculados a Secretarias Estaduais de Saúde (Nota dos Orgs). 
'contaminação', por exemplo, partindo de representaçōes de vida, de como as pessoas vivem e adoecem. E, então, a partir desse grande círculo, chegar ao que seja 'contaminar' no sentido estrito mesmo, da agulha, da seringa, de um procedimento médico.

O caminho percorrido para chegar a essa conclusão começa no entendimento das formas de sobrevivência de determinada população, para depois alcançar o conceito desejado. Isso é que traz para dentro do biológico a dimensão do social, do antropológico, do cultural. Resgatar tudo isso e possibilitar uma visão mais geral é a experiência das pessoas que passaram pelo processo. O Projeto Larga Escala, em si, não contempla a educação geral. Ele tenta oferecer, em paralelo, reflexões sobre linguagem, operações básicas etc. $O$ Larga Escala tem-se preocupado muito com a especificidade da habilitação. Quando uma pessoa não tem a formação completa exigida pelo $\mathrm{MEC}$, recebe somente o certificado de habilitação, que não a credencia como técnico ou como auxiliar da categoria. A escola técnica tem que dar resposta também a essa questão.

Acho necessário que, além da oportunidade da escolarização, sejam postos à disposição da população centros públicos de formação profissional. O que existe hoje fora da rede escolar são instâncias de formação profissional controladas pelo capital e que têm todo empenho em fazer uma profissionalização muito operacional, sem a devida compreensão do processo. Nem sempre poderá ser feita a referida integração, principalmente considerando o trabalhador que está no mercado, que já foi prejudicado em relação à sua escolaridade normal. Então, é importante que existam centros de formação profissional que dêem uma visão mais pública, mais preocupada com o sentido de coletividade, com a importância do social, oferecendo oportunidades de profissionalização ao trabalhador já engajado ou até mesmo àquele que vai poder cursar somente o primeiro grau e precisa ter alguma habilitação para entrar no mercado. É fundamental que a pessoa não seja duplamente punida por ter que substituir o horário que seria dedicado à formação básica por outro que lhe proporcione a aquisição de uma série de informações sobre determinada ocupação.

Na formação do trabalhador hoje, especificamente daquele já inserido no serviço de saúde, não se deve perder a dimensão de que é uma atividade estratégica, mas temos que apostar na possibilidade de que, num determinado momento, algumas atividades não sejam mais necessárias. Elas hoje o são porque as relações de trabalho, as relaçōes da sociedade estão impondo essa necessidade e, portanto, não podemos perder de vista essa necessidade conjuntural (ou emergencial). Considero que atuar com o trabalhador é muito mais dificil do que com adolescentes que cursam o segundo grau regular. A formação dos trabalhadores engajados nos serviços de saúde enfrenta dificuldades muito maiores por vários mo- 
tivos. É muito mais fácil a alguém que percorreu o sistema de ensino aprender a executar determinada técnica no momento de inserir-se no trabalho do que ocorrer o inverso: uma pessoa inserida há tempos no trabalho assimilar novo conhecimento, o que, no meu entender, dificulta a superação de deficiências.

\section{Alina Souza}

Uma das maiores críticas que se faz ao Projeto Larga Escala é em relação ao tempo: "É um projeto que demora muito". Ele demora muito porque a metodologia adotada é para atuar no interior mesmo do trabalho, do serviço. É muito calcada em dois tempos, e não apenas naquela idéia mais comum da educação, que se referencia apenas no tempo de o indivíduo aprender. Há também um tempo do coletivo, porque o processo não se dá numa metodologia estritamente individual, numa relação instrutor-aluno. Ela depende do que estiver sendo feito pelo coletivo e depende da organização dos serviços de saúde. Por exemplo: consta do currículo que, em determinado momento, tem que se ensinar a aplicar vacina. Esse assunto está no currículo tradicional, mas, como é um processo educacional baseado no trabalho, para que esse ponto da unidade seja cumprido, é preciso que o serviço de saúde tenha os instrumentos necessários a esse aprendizado. Se o serviço năo tiver, a unidade năo avança. Ele é um projeto que está acoplado à idéia de formar na perspectiva da organizaçăo do serviço de saúde. Se tenho compromisso com a escola técnica do sistema formal, posso montar um laboratório e ensinar. Na proposta do Larga Escala, não existe a possibilidade dessa situaçāo (dita simulada) de ensinar um procedimento que não vai ser executado ou vai ser executado apenas ocasionalmente.

Por outro lado, se não existe o projeto político da reorganização do serviço, não ocorre a possibilidade de fazer o currículo. Por isso, demora dois, três anos, e demora por outra razão também: como podemos pensar que nossas classes marginalizadas da educação tenham que aprender em cursos de um, dois meses, quando nós mesmos, elite, intelectuais, passamos na escola mais de vinte anos? O Projeto Larga Escala sofre essa crítica do tempo, que é insuperável. Na tentativa de resgate profissional, alguns avançam mais depressa, outros menos, mas o tempo é muito maior do que nos treinamentos tradicionais que o serviço de saúde propiciou ou, historicamente, vem propiciando. 


\section{A QUESTÃO TECNOLÓGICA E A QUALIFICAÇÃO PROFISSIONAL}





\section{CIÊNCIA, TECNOLOGIA E QUALIFICAÇĀO PROFISSIONAL EM SAUUDE}

Marília Bernardes Marques

A respeito do tema ciência, tecnologia e qualificação profissional no Brasil, inexistem estudos setoriais que forneçam uma base empírica para refletir sobre as conseqüências que a tecnologia vem acarretando sobre o mercado de trabalho em saúde. Na verdade, há pouquíssimos estudos sobre esse assunto até mesmo em relação ao mercado de trabalho em geral, com exceção de algumas pesquisas específicas sobre os setores automobilístico e de serviços, em especial o bancário. A situação é bastante diferente nos países industrialmente avançados, onde já existem estudos não apenas empíricos, mas também analíticos da expressão e dos enfrentamentos políticos nessas sociedades, resultantes dos impactos causados pela tecnologia.

No Brasil, a Lei $5.692 / 71$ propôs uma reforma de ensino de primeiro e segundo graus no início dos anos 70 , no clima do 'milagre econômico'. Tal reforma era interpretada como uma verdadeira panacéia, por meio da qual o País iria superar a questão das desigualdades sociais. Essa idéia, entretanto, não era condizente com o modelo de 'Brasil potência' que o autoritarismo, entāo, estava projetando. Na verdade, essa lei tinha por objetivo impedir que o aluno terminasse o segundo grau sem que estivesse qualificado para o trabalho.

O subdesenvolvimento brasileiro se expressa, no mercado de trabalho, pelas elevadas taxas de participação das faixas etárias extremas - idosos, adultos jovens e menores de quinze anos - como força de trabalho, indicando que, de modo geral, a duração da vida escolar no Brasil é acentuadamente menor que a verificada nos países industrializados. Comprova ainda a situação de subdesenvolvimento o fato de haver apenas três milhōes e meio de pessoas formadas no nível superior. Desse total, apenas 1,5\% são pesquisadores, o que corresponde a uma taxa de quatro pesquisadores para cada dez mil habitantes, enquanto nos países industrialmente avançados esse índice alcança quarenta pesquisadores por dez mil habitantes, ou seja, é dez vezes maior. 
Outro aspecto importante é a taxa de formalidade no mercado de trabalho do País, que vem registrando uma acentuada tendência de queda desde a década de 80. A taxa de formalidade expressa o percentual dos trabalhadores com carteira assinada, mais os estatutários da administração pública, ou seja, o percentual desse contingente em relação ao total da população ocupada. Em 1979, a taxa era de $42 \%$; em 1986, caiu para $40 \%$, ou seja, $60 \%$ da populaçăo trabalhadora estava na informalidade, o que projeta um agravamento da situação.

Tais dados sugerem que o setor produtivo está concentrando seus lucros nos ganhos não-operacionais, fazendo investimentos nāo-produtivos e utilizando métodos informais para contratar mão-de-obra. Nos últimos vinte anos, tem-se verificado uma tendência de queda da participação da renda do trabalho, ou seja, a parte correspondente a salários mais encargos sociais tem caído na composição do PIB brasileiro. A renda do trabalho participou com 38,67\% do PIB em 1980; em 1970, com 40,7\%; para 1985, a projeçāo é ainda mais baixa, com uma perspectiva de cerca de $36 \%$; para 1988, esse índice cai para 33\%. Nos Estados Unidos, por exemplo, a situação é bem diferente: o rendimento do trabalho atinge uma taxa de $60 \%$ de participação no PIB, que, por sua vez, é muito maior do que o nosso. Para se ter uma idéia, enquanto o PIB brasileiro, em 1988, ficou em torno de US\$370 bilhōes, apenas o gasto em saúde nos Estados Unidos alcançou US\$ 550 bilhōes no mesmo ano.

No Japão, a renda do trabalho participa com $70 \%$ do PIB, e, na França, com $61 \%$. Perdemos até para o Paraguai. Somente o Equador e o Peru conseguem ter taxas ainda menores que as do Brasil. Nos países industrializados, o repasse de parcela dos ganhos de produtividade para os salários explica a elevação da participação da renda do trabalho no PIB. Isto é: do total que corresponder, na economia como um todo, à elevação de ganhos de produtividade, uma parte importante será repassada aos salários. Por esses indicadores, constata-se que o nosso modelo de desenvolvimento econômico está penalizando o investimento produtivo, premiando a aplicação de recursos na ciranda financeira, punindo quem trabalha, porque nāo está repassando eventuais elevaçōes de produtividade para a composiçāo do salário.

Para uma população economicamente ativa de 53 milhões, temos no País 44 milhões de pessoas ganhando menos de cinco salários mínimos, ou seja, a massa, o povo brasileiro, ganha muito pouco. Enquanto temos apenas de 30 a 35 milhōes de cidadāos integrando a sociedade de consumo, mais de cem milhōes de brasileiros estāo vivendo completamente à margem de padrões mínimos de consumo. Isso revela como o mercado interno brasileiro está brutalmente contido.

Em resumo, o Brasil é um país que hoje apresenta altos níveis de miséria social, de desemprego e subemprego estrutural e cíclico, e tendência de retrocesso da participação dos salários no PIB. Assim, é consenso a necessidade de formular rapidamente um modelo de desenvolvimento que possibilite ao País sair dessa cstagnaçāo econômica e retomar o crescimento sob um modelo que propicie maior par- 
ticipação dos salários na composição do PIB. E esse modelo, a nosso ver, para ser viável, deve ter como referência três pontos nodais: a modernização tecnológica, a distribuição da renda e a democracia. São os três pontos básicos para delinear um modelo de retomada do desenvolvimento econômico, porque o futuro do emprego e o processo de modernização tecnológica estão hoje - e isso é um fenômeno mundial - estreitamente vinculados.

Por ser hoje a economia brasileira bastante internacionalizada e, ao mesmo tempo, com um grau de atraso tecnológico muito acentuado, a demanda para a modernização tecnológica é muito grande e, com poucas exceçöes, ocorre em quase todos os setores. Esse atraso tecnológico vem atingindo mais as pequenas e médias empresas nacionais e as empresas mais jovens, justamente empresas que são empregadoras de mão-de-obra, que têm um número de trabalhadores maior em relação ao capital investido em máquinas. Esse atraso tem reflexos nos baixos índices de produtividade que a economia apresenta e nas sérias deficiências de qualidade e confiabilidade apresentadas por muitos produtos industrializados, que diminuem a competitividade da economia nacional. Apontar dados relativos à indústria não significa que a agricultura năo tenha importância, porém, quando se trata de desenvolvimento, a indústria tem um papel primordial, ao impor o ritmo e o padrão do desenvolvimento. Não se está negando, portanto, a importância, a pré-condiçăo e mesmo a complementaridade da agricultura.

Sabemos, entretanto, inclusive porque vivemos essa experiência na história recente do País, que não basta apenas o crescimento econômico. O Brasil experimentou um crescimento econômico fantástico na época do militarismo, mas foi um crescimento que se deu sem a preocupação de trazer, para dentro das fronteiras nacionais, a capacitação tecnológica e o controle não apenas de tecnologias avançadas e de ponta, mas da tecnologia de modo geral. O modelo de desenvolvimento industrial e tecnológico, baseado em substituição de importações, modernizou o Brasil, tornando-o um país industrializado, porém cabe indagar em que consiste essa modernidade que não se preocupou com a questão do controle da capacitaçāo tecnológica. Essa industrialização acabou por posicionar o Brasil, na escala mundial, na frente ou lá atrás em matéria de miséria social?

Necessita-se, obviamente, de modernização tecnológica, mas com controle decisório e com capacitação tecnológica ativa, endógena, nacional, em nossa indústria farmacêutica, em nossa indústria de produtos alimentares, em nosso complexo têxtil, em nosso complexo de couro e calçados, em nossa petroquímica. $\mathrm{O}$ futuro do emprego está vinculado, qualitativa e quantitativamente, a essa questão da modernização tecnológica. No futuro, se a inserção da economia brasileira no mercado internacional continuar sendo dependente, vai ocorrer a completa desnacionalização da nossa capacidade de investir e de produzir. Em outras palavras, as decisões sobre em que setor investir serăo tomadas fora das fronteiras nacionais. 
Nesse modelo dependente, a única vantagem que o Brasil tem a oferecer internacionalmente e a trazer para a mesa de negociação - se é que se pode falar de negociação quando se está de joelhos - é o baixo custo da mão-de-obra e seus preciosos recursos naturais, alguns à beira do esgotamento, tanto os renováveis como os não-renováveis. Esse modelo dependente continuará correspondendo a essa modernidade enganadora, que nos confundiu, mas que não se pode mais aceitar, porque hoje convivemos com uma situação ímpar de profunda iniqüidade social e violência. Essa modernidade, e isso está claro pelo menos no segmento mais consciente da sociedade brasileira, não serve mais. Uma via de desenvolvimento econômico que tenha como prioridade a satisfação das necessidades sociais da população exigirá crescimento com elevação dos salários reais e um padrão de consumo no mercado interno sem as distorções atuais resultantes da brutal concentração de renda hoje existente. Esta segunda via, não-dependente, exige a transformação da estrutura industrial a partir da tecnologia, ajustada a uma demanda do mercado interno que resulte da ampliação de programas sociais e da elevação de salários reais; que resulte na produção para o consumo de bens mais baratos e em maiores investimentos em infra-estrutura social.

É necessária uma estrutura produtiva eficiente, moderna, automatizada e com competitividade internacional para atender a esse acúmulo brutal de necessidades sociais não satisfeitas. Não há outra alternativa. É preciso ter competitividade internacional e vencer o desafio do mercado externo, para garantir o desenvolvimento econômico interno. Para o Brasil, a questão tecnológica, por isso mesmo, não pode ser colocada apenas nos termos dos efeitos negativos sobre o mercado de trabalho, porque até parece que já estamos na ponta, que somos um país industrialmente superavançado, discutindo os impactos negativos da tecnologia sobre o mercado de trabalho. Desse modo, embora seja um aspecto extremamente relevante, não podemos centrar nossa discussão apenas na eliminação ou diminuição de postos de trabalho pela incorporação da tecnologia, como se dá no caso da automação.

A opção por um modelo de desenvolvimento que não seja tecnologicamente sustentável ou sustentado poderá revelar um custo social muito maior. A perda da competitividade da indústria brasileira terá como conseqüência a diminuição do mercado para os seus produtos, o que conduzirá à redução da produção e das taxas de emprego e, conseqüentemente, ao aumento do desemprego. O grande desafio para um país como o Brasil é a escolha tecnológica correta, visando à modernização tecnológica. E esta deve ser apoiada na questão política e no correto balanceamento entre a exigência de elevar a competitividade das empresas e a geração de postos de trabalho. É necessário, pois, vencer esse desafio. Isso passa pela combinação inteligente de políticas públicas, de políticas dirigidas ao desenvolvimento e relacionadas com a questão da introdução da inovação tecnológica na economia e seus impactos sobre o mercado de trabalho e o ambiente. As implicações dessas novas tecnologias sobre o mercado são também qualitativas. Elas criam uma nova maneira de produzir e fazem com que certas profissőes se tornem obsoletas e sur- 
jam novos profissionais, com exigências de qualificação distintas das atuais. Na verdade, a própria natureza do trabalho está sendo profundamente alterada pelas inovaçōes tecnológicas. Isso ocorre menos pela ação em si da nova tecnologia incorporada, como no caso da microeletrônica, mas muito mais pela maneira como está sendo introduzida e incorporada.

Assim, é principalmente a orientação que se imprime, por exemplo, à utilização de controles automatizados na produção industrial ou de serviços que irá determinar o caráter ou as características de suas implicaçōes sociais. É uma questão de escolha política. O problema da opção tecnológica é, portanto, crucial no que se refere às decisōes referentes ao processo de inovação tecnológica. Para o Brasil e para outros países do Terceiro Mundo, ainda é possível a escolha de um modelo de desenvolvimento econômico equilibrado social e ecologicamente. Ainda temos uma oportunidade que nos está sendo dada justamente pela questāo da tecnologia avançada, pela questão da microeletrônica, pela questão da biotecnologia etc., isto é, pela possibilidade que essas tecnologias oferecem de revolucionar as relaçöes e o controle do processo de trabalho, bem como o impacto sobre o meio ambiente. No caso da microeletrônica, houve uma decisão política. A área de informática é, efetivamente, aquela em que se traçou claramente uma política industrial. E os resultados estão aí. Com distorçōes, mas são resultados inequívocos. $O$ sucesso brasileiro explica por que no Gatt (Acordo Geral de Tarifas e Comércio), fórum de negociação que tem estado a serviço dos interesses norte-americanos, o Brasil está sendo alvo de pressóes espantosas e retaliaçōes. No campo do software, vem-se alcançando também uma boa projeção. No caso da biotecnologia aplicada à saúde, das novas tecnologias de engenharia genética, é grande a tradição do Brasil em matéria de pesquisa biomédica nas instituições públicas, como a Fiocruz.

O Brasil é competente em biotecnologia graças, em grande parte, à Fiocruz, que tem uma longa tradição na área biomédica e na pesquisa aplicada. Foram os sanitaristas, companheiros de Oswaldo Cruz, que criaram os alicerces para o atual desempenho internacionalmente reconhecido no campo das novas biotecnologias. $\mathrm{Na}$ Fiocruz, portanto, temos uma responsabilidade política enorme com relação ao futuro deste país. Evidentemente, a mudança tecnológica ou o progresso tecnológico têm condicionantes sociais e políticos. A mudança tecnológica é produto de relaçōes sociais determinadas e marca profundamente os trabalhadores por meio das alteraçōes que promove na natureza e nas relaçōes de trabalho que se estabelecem no interior da empresa. Então, a difusão das inovações tecnológicas opera mudanças na divisão social do trabalho, alterando profundamente as características da força do trabalho. Ocorrem mudanças na composição das ocupaçōes, na qualificação, na escolaridade, e, para diferentes categorias de trabalhadores, altera-se a importância de cada uma das ocupaçōes no mercado de trabalho, com algumas qualificaçöes se tornando obsoletas e outras novas surgindo, altamente valorizadas. Basta citar o exemplo dos analistas de sistemas e programadores, profissionais cuja valorização no mercado atingiu patamar tão elevado a ponto de a Fiocruz não ter hoje, 
em termos salariais, a menor competitividade, em virtude da enorme diferença entre os salários que oferece e os praticados pelo setor privado.

Essa valorização, na área biomédica, aponta para um tema muito interessante: a incorporação de tecnologia moderna suscita a indagação a respeito do futuro de parte dos especialistas médicos, porque há indicaçōes de que esse tipo de profissional sofrerá um processo de 'desqualificação', isto é, será substituído por um engenheiro biomédico ou por profissionais de computaçăo. Para esse exercício de prospeç̧ão, há que buscar dados empíricos, talvez nos estudos sobre avaliação tecnológica e impactos sobre o mercado profissional médico, em países como os Estados Unidos, por exemplo. Inovaçōes tecnológicas podem trazer efetivamente alterações revolucionárias na organização do trabalho, e, no mundo, a difusão da microeletrônica trouxe o sistema da subcontratação, retornou ao velho sistema da produção no nível doméstico, realizada no domicílio, em diversos setores industriais e também nos serviços. Com o desenvolvimento de máquinas e ferramentas com controle numérico, o indivíduo pode trabalhar em casa. Isso está acontecendo também no Brasil, e, na área automobilística, há estudos que apontam nessa direção. Existe uma forte tendência à descentralização do trabalho, fato que tem implicações importantíssimas para a discussão na área sindical. Assim, o desenvolvimento tecnológico e as mudanças no processo de trabalho são politicamente condicionados, $e$ isso é bom, felizmente, porque senão a técnica estaria caminhando autonomamente, com seus impactos sociais e ambientais potencialmente negativos.

Chamo a atenção para essa condicionalidade política e social, isto é, mudanças no processo de trabalho se materializam conforme limites dados pelas relações entre capital e trabalho e pela intervenção do Estado, por meio das políticas públicas, com destaque para a política de desenvolvimento industrial e a política científica e tecnológica, que têm uma forte influência, um papel estratégico no rumo a ser tomado pelo País. Forte influência também deverá exercer a resistência sindical à inovação tecnológica que desemprega, que desqualifica. Há exemplos para alertar que um equívoco de encaminhamento do movimento sindical poderá acarretar perda de competitividade, perda de mercado e desemprego acentuado em alguns setores, como aconteceu na Inglaterra em relação ao setor gráfico. Então, é preciso que essa resistência em termos de consciência política se apóie na compreensão do processo tecnológico.

A inovação tecnológica, em si mesma, não predetermina nada, embora haja uma interpretação a partir da teoria marxista de que a própria natureza da tecnologia, sendo ela produzida no capitalismo, está condicionada aos desígnios do capital. Não acredito que a inovação tecnológica em si predetermine as conseqüências que sua difusão terá sobre o mercado de trabalho ou o meio ambiente. A organização social por meio da qual a tecnologia é incorporada ao trabalho é que terá relevância. Daí a ênfase na questão da democracia, posto que a participação política nas decisões referentes à introdução da inovação tecnológica numa sociedade de- 
mocrática pode imprimir rumos diferentes à condução do processo. A organização política é fundamental, porque facilita ou dificulta os efeitos quantitativos e qualitativos negativos sobre a força de trabalho e o meio ambiente. Assim, a tradição e a força do movimento sindical podem estabelecer limites aos impactos negativos da tecnologia. Desse modo, existe uma clara dialética, pois, se a tecnologia afirma a desqualificação como tendência, esta tendência é acompanhada também pela criação de novas qualificações. Se a tecnologia fornece ao capital meios mais eficazes de controle do processo de trabalho, ela prevê a melhoria das condições de trabalho para certos grupos profissionais, exigindo também que questões como a da responsabilidade em termos do trabalho passem a ter uma dimensão política extraordinária, envolvendo também a elevação do nível dos salários para algumas categorias. Não existe essa tendência inexorável à degradação do trabalho diante da inovação tecnológica, principalmente num país como o nosso, com o quadro inicial aqui apresentado. É preciso ter muita clareza quanto a essa questão.

O Brasil não sairá da situação atual num espaço curto de tempo, mas o que se decidir agora é crucial para o futuro e para alterar essa situação econômica de desemprego, de subemprego, de economia subterrânea, de miséria social. É preciso escolher um modelo de desenvolvimento que confira a mais absoluta prioridade à produção de ciência, ao desenvolvimento científico e tecnológico, e à educação, desde a erradicação do analfabetismo até os cursos mais especializados.

Para o Brasil, a ação do Estado deverá ser apropriada à complexidade atual da sociedade brasileira. Em matéria de política científica e tecnológica, temos tido em nossa história - curta, mas importante - fatos marcantes, como a criação do CNPq, do BNDES, da Finep e da Capes. Nesse arcabouço que temos hoje, a política científica não pode ser vista como um investimento puro e simples na produção científica, que, no País, tem estado muito distante do desenvolvimento tecnológico, e só recentemente algumas universidades vêm assumindo o papel de dinamizadoras do desenvolvimento econômico e tecnológico. A política de ciência e tecnologia não pode buscar simplesmente o desenvolvimento científico, distribuindo bolsas e recursos entre uma elite de cientistas que possivelmente irăo dizer que "o pes-

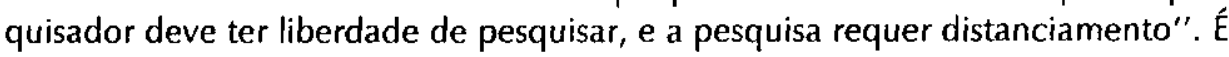
claro que a autonomia das instituições universitárias e de pesquisa tem que ser considerada estratégica para fortalecer o nosso desenvolvimento, mas não aquele tipo de autonomia que coloca a instituição como uma autarquia distante das políticas do governo. A política de ciência e tecnologia em saúde tem que ser discutida em suas relações de integraçăo com outras políticas, como a do emprego, a de salários, a de educação, a de saúde.

Analisando o segundo grau na área da saúde, encontrei vinte e duas qualificaçóes. Procurei identificar, nesse conjunto, cursos para profissionais, de diferentes níveis, de ciência e tecnologia em saúde. Não encontrei, lamentavelmente, habilitações que correspondessem à minha expectativa. A pesquisa biomédica e a pes- 
quisa clínica comportam determinadas disciplinas, determinados domínios e, em ambos os campos - mesmo sem considerar o caso da produção industrial ou da prestação de serviços na área de controle de qualidade ou de serviços de saúde -, não encontrei a menor relação entre essas disciplinas e as habilitações legais. $\mathrm{Na}$ legislação, há um descompasso evidente, um distanciamento em relação à realidade. Isso pode estar traduzindo a total desarticulação entre as políticas de educação e as outras, nas quais se inserem as políticas científica e tecnológica.

Parece-me que, na análise sobre a formação profissional na saúde, privilegiar a variável tecnologia é um excelente ponto de partida. Temos que pensar a Fiocruz como um espaço estratégico, como um laboratório exemplar para discutir e planejar a qualificação profissional em saúde. Creio que esse tema vem sendo tratado como se já fôssemos um país altamente industrializado. Devemos estar atentos para os impactos da tecnologia, mas sem perder a consciência do país que somos e, dentro desse país, a instituição em que atuamos, sobre a qual reside uma enorme expectativa da sociedade em relação ao papel que desempenhará no futuro. A responsabilidade aumenta no momento em que se caminha para uma mudança de governo, para uma mudança na presidência da Fiocruz, em que se vive o processo de mudança nas unidades técnico-científicas. Todos esses fatos chamam a atenção para a situação crucial que atravessa a comunidade de pesquisadores, tecnólogos, professores e médicos que compöem a 'Universidade da Saúde' que é a fiocruz. Há nesta instituição um elenco de atividades que também expressam um elenco de tecnologias, na medida em que cada atividade reúne uma ou mais tecnologias para o seu desenvolvimento. 


\section{QUALIFICAÇÃO TÉCNICA E QUALIFICAÇÃO SOCIAL: EM BUSCA DE UMA VISÃO PÓS HABERMASIANA}

Rogério Valle

Pode-se imaginar qualificação técnica e qualificação social como duas esferas que se opōem, as quais sabemos constituídas de matérias diferentes, mas que temos dificuldades em separar. Pretendo analisar a relação existente entre as duas segundo uma perspectiva diacrônica.

Em um momento inicial, a técnica foi tratada como algo à parte da sociedade. Tinha-se o progresso técnico como algo linear, autônomo em relação às opções políticas e às características culturais da sociedade. Essa era, mais ou menos, a visão dominante no final do século passado, quando o evolucionismo, o naturalismo, o racionalismo eram as tendências prevalentes. Até mesmo Marx não escapou dessa concepção, ainda que tenha tentado ser mais dialético do que evolucionista (ele, afinal, năo poderia ser melhor do que o seu próprio tempo...). $\mathrm{O}$ desenvolvimento acelerado da economia mundial capitalista no século $X X$ reforçou muito a idéia do 'determinismo técnico', segundo a qual a sociedade seria determinada pela evoluçāo da técnica, tendência assumida, grosso modo, tanto pela direita quanto pela esquerda.

Somente com os teóricos da Escola de Frankfurt é que se rompe com essa visão determinista. Marxistas que leram Weber começaram a perceber que o desenvolvimento técnico-científico constituía uma ameaça à evolução da sociedade e nāo era apenas algo vantajoso. Entāo, da "técnica e ciência como libertadoras", passa-se à concepçāo da "técnica e ciência como opressoras". Marcuse, um dos mais conhecidos pensadores dessa Escola, afirmava que uma nova sociedade exigia uma nova técnica e uma nova ciência. Mas outros 'frankfurtianos' foram bem mais radicais. Adorno, no fim da vida, afirmou que somente a arte traria a salvação, fora do estético nada poderia ser feito, o mundo estava se aproximando do fim. A Escola de Frankfurt foi dominada por forte pessimismo. Seus teóricos não vislumbravam saídas, na medida em que modernização era racionalização, e racionalidade significava exclusivamente a racionalidade instrumental. 
No Brasil, essas duas concepçóes influenciaram primordialmente a esfera acadêmica. Com a fase desenvolvimentista, a própria universidade brasileira começou a acreditar bastante nessa idéia do determinismo técnico. Em várias análises, os próprios sociólogos discutiam o nível de modernidade nos setores industriais, como se ele fosse capaz de determinar a consciência dos trabalhadores. Uma série de pesquisas, nos anos 50 e 60 , demonstrava ser a natureza da consciência dos trabalhadores conseqüência do setor industrial em que atuavam ou, mais exatamente, do grau de modernidade desse setor.

Quanto à visão da Escola de Frankfurt, ela acabou ressoando no País de forma indireta. No Brasil, não se tem consciência de que a crítica à ciência e à tecnologia surgida nos anos 70 é uma conseqüência da ruptura introduzida por aqueles teóricos alemães. Foi a partir da leitura de autores como o francês B. Coriat, por exemplo, que surgiu uma série de teses sobre as influências socialmente negativas do desenvolvimento técnico, criticando-se duramente a organização taylorista do trabalho como forma de controle dos operários. Sem dúvida, o controle é exercido, mas é uma simplificação extrema reduzir toda a técnica ao taylorismo, como se ele tivesse sido utilizado em todas as indústrias, o que de fato nāo ocorreu. Enfim, analisava-se o modelo taylorista e concluía-se que técnica era sinônimo de opressão.

Essas duas visões parecem inadequadas porque são exclusivamente sistêmicas. Analisa-se, de um lado, a sociedade como um sistema social a ser regulado, segundo a melhor tradição da sociologia americana. É o sistema que nos oprime, como se dizia no fim dos anos 60 e início dos 70 . A culpa é do sistema, não há nada a fazer, porque ele está em todo lugar. A sociedade seria exclusivamente um sistema social, caracterizado por um desenvolvimento tecnológico intenso e a fábrica seria um subsistema social. Só haveria opressão e nenhuma forma de resistência dos trabathadores seria possivel.

Ora, a realidade não é só essa. A sociedade é construída, também, pela resistência das pessoas, que reagem à 'burrificação' geral. Somos capazes de indignação diante da estupidez. Essa é a minha opinião a partir do que venho observando em fábricas brasileiras. Aliás, sem uma análise da resistência operária, não é possivel entender realmente o que é produção, nem o que é técnica. Embora não seja um estudioso da área, arrisco-me a afirmar que é impossível entender algo sobre o sistema de saúde brasileiro se acreditarmos cegamente no que está escrito. É preciso ver como é a ação real das pessoas, se elas se conformam com as normas escritas. Seria interessante verificar se há uma organização informal ao lado da formal. Dentro dessa organização informal (que freqüentemente é vista como 'bagunça', e muitas vezes realmente o é), com freqüência há também muito de resistência à opressão, resistência aos aspectos negativos da sociedade.

Enfim, essas duas visões, em que só há o sistema, carecem de uma perspectiva que a fenomenologia alemã chamava de 'mundo da vida'. Não vivemos num sistema social que nos domina, que nos empurra inexoravelmente para uma so- 
ciedade tecnocratizada, de um lado, ou, então, para o controle total. A sociedade não é apenas uma grande máquina. A sociedade industrial, é verdade, vive tão fascinada pelo exemplo da máquina, que ela própria, em alguns casos, se comporta como uma máquina de opressăo e, em outros, como uma máquina de libertação. Parece-me, entretanto, que se, por um lado, ela é um sistema, por outro, é também um mundo da vida que corresponde à perspectiva interna (não à perspectiva externa, de quem está de fora). O sistema é a visāo da sociedade de quem está do lado de dentro e constata que existem a opressão e a resistência, o positivo e o negativo, a dor e a alegria, o trabalho e o lazer. Então, essa visão interna é elaborada a partir da experiência de vida dos participantes da construção da sociedade.

$O$ ideal, então, seria conseguir reunir a perspectiva sistêmica e a perspectiva do mundo da vida. Como reunir essas duas perspectivas? Creio que ambas săo necessárias. É preciso olhar as coisas de fora e de dentro. É necessário saber que, olhando as coisas do lado de fora, não se tem o conhecimento total da realidade, porque há muitos aspectos por dentro que deixam de ser vistos. Também é necessário saber que, estando-se dentro, muitas vezes, perde-se a visão global.

Voltando ao tema que me foi apresentado: como honrar as exigências que nos sảo feitas, seja pela técnica, seja pelo social? Partindo da hipótese de que desejamos caminhar para uma sociedade mais justa, temos que evitar dois tipos de deformação ideológica. A primeira é a idéia de legitimar decisōes políticas por meio da técnica. A técnica não tem efetivamente o poder de legitimar questōes que dizem respeito à própria vida política. Isso, como dizia o primeiro Habermas, é transformar a técnica em ideologia. A técnica pode se transformar em ideologia quando invocada para responder a um problema social, que merece uma reflexão própria, um tratamento segundo a racionalidade própria da instituição política, por exemplo. Por outro lado, não podemos também nos deixar levar por um voluntarismo político que julgue poder passar por cima de assuntos que requerem reflexão propriamente técnica. Não é possivel realizar tudo o que desejamos politicamente. Algumas metas são exeqüíveis, outras não.

Em suma, não pode haver uma separação radical entre a técnica e a sociedade, nem tampouco uma fusão entre elas. A primeira visão, aquela do progresso técnico linear e autônomo, separava a técnica da sociedade. A segunda visão, de Marcuse e outros, confundia técnica e dominação, numa fusāo entre os dois domínios. É preciso compreender que se trata de duas esferas que năo vivem em situação de estranhamento mútuo, nem de completa confusão. Na verdade, essas duas esferas possuem uma racionalidade própria, racionalidade técnica de um lado, racionalidade social de outro, mas que se questionam incessantemente.

Sem invocar, mais uma vez, a 'solução dialética' de que todos falam, mas ninguém sabe bem o que é, penso que a ação é possível. Acredito, sim, na dialética, desde que enfocada a partir da prática. Não estamos completamente dominados por sistemas que nos oprimem. Compreende-se que essa idéia tenha sido alimen- 
tada enquanto vivíamos sob uma ditadura, mas já está na hora de dar um passo além, se nosso objetivo é realmente construir uma sociedade mais justa. É no âmbito da açăo que nos cabe encontrar respostas para esse questionamento incessante, que vem da técnica e do social. Para encontrar um equilíbrio dinâmico entre essas duas esferas, é necessário certo tipo de lucidez, que pode ser ajudada por alguns métodos. (Felizmente, há métodos para nos ajudar.) Por exemplo, uma discussăo coletiva entre os participantes interessados diretamente no assunto, uma discussão multicritérios, e não a partir de um critério só, o econômico, por exemplo. Um debate a partir das conseqüências possíveis de uma solução técnica (ecológicas, sanitárias, éticas etc.). Uma tomada de decisão coletiva, com troca de argumentos ligados a cada esfera, coerentes do ponto de vista técnico, mas também em face do projeto social que se tem. Certamente, uma reflexão nesses termos é capaz de nos levar a uma ação lúcida. Uma ação que seja capaz de equilibrar as exigências que nos vêm desses dois domínios.

Para que um debate como esse seja possível, há várias condiçōes. Em primeiro lugar, condiçōes políticas mais amplas. Não vou detalhá-las, porque me parecem bastante claras. Mas há ainda uma exigência ligada à capacidade de argumentar dos diversos agentes. É uma ilusão - freqüentemente, bem mais do que isso pensar que se pode garantir uma decisão democrática simplesmente juntando pessoas que nunca falaram em público, que nunca tiveram direito à palavra, com outras que estão acostumadas a lidar com esse tipo de discurso (um político, por exemplo). Não basta apenas dizer: "meus caros, a palavra está aberta; que cada um fale...". É preciso que as pessoas tenham a capacidade de saber defender seus argumentos. $E$ aí chegamos ao problema da qualificação. A condição inicial para esse debate seria que os participantes tivessem qualificação técnica e sociológica, bem como clareza para não confundir esses domínios.

Numa sociedade moderna - nisso Weber tinha razão -, as esferas de valor seguem leis autônomas. Isso é razoavelmente claro. O que não é óbvio é que, por causa disso, devamos abandonar a perspectiva de uma conciliação dialética entre essas esferas no nível da experiência. Porque é no nível da experiência, no nível de nossa ação, que é possível realmente fazer essa síntese. De fato, ela é muito mais difícil no plano das idéias.

É muito simples afirmar isso, mas tenho a esperança de que consigamos, por meio de nossa ação, dar passos firmes no sentido de um equilíbrio entre a lucidez técnica e a sociológica que nos conduza a uma sociedade menos injusta.

Sintetizando, a questão da qualificação - que está ligada à da educação - requer uma discussão entre o social e o técnico. No entanto, para que haja um verdadeiro debate; para que se tome, democraticamente, uma decisão sobre implantar ou não tal rede de esgotos em tal bairro; para escolher uma alternativa entre soluções técnicas que devam ter repercussão muito forte na vida da comunidade interessada; para que o debate não seja simplesmente ilusório, é necessário que seus participantes tenham qualificação técnica e qualificação sociológica, com conhecimento da realidade a ser enfrentada. 


\section{DEBATE}

A partir da temática da tecnologia, parece muito interessante discutir, por exemplo, riscos e questöes relacionados à saúde dos trabalhadores, o problema do ambiente, a questão do consumidor. Ela permite pensar em algumas evoluções conceituais, como o próprio conceito de risco. No debate sobre o valor inerente ao desenvolvimento, quando se discutem os aspectos destrutivos desse desenvolvimento, de maneira geral há uma tendência a negar ou a atacar essa possibilidade. Até hoje, mantemos a idéia do acidente dentro de uma concepção aristotélica, como um evento indesejável, atribuído normalmente a uma falha de um processo, de um sistema. A evolução nas abordagens sistêmicas e nas perspectivas tanto da ergonomia como de outras áreas sistêmicas, como, por exemplo, na área de acidentes, vem mostrando a inerência sistêmica do próprio acidente, e isso, relacionado à tecnologia, indicaria o risco relacionado a determinadas tecnologias.

A tecnologia é, antes de mais nada, uma rearrumação de energias não só humanas, mas também da natureza. Essa rearrumação, por vezes, gera concentraçōes estupendas. Temos falado desse conjunto de tecnologias na sua relação com o homem e com a natureza, provocando rupturas ecológicas. Nesse sentido, poderímos pensar que o desenvolvimento da velocidade é o desenvolvimento dos acidentes da velocidade. Essa é uma discussão que normalmente não se trava quando se discute trânsito. Verifica-se que mesmo os sistemas mais avançados de trânsito apresentam taxas de acidentes razoavelmente significativas. Ou seja: a evolução dos sistemas energéticos permitirá gerar energias cinéticas mecânicas fabulosas. Essa mesma questão ocorrerá também na indústria química, pois cerca de mil novas substâncias são colocadas anualmente no mercado mundial sem o devido conhecimento epidemiológico de seus efeitos a curto, médio e longo prazos. Nos Estados Unidos, o controle dessas substâncias no nível ocupacional só se dá em cerca de cinco centenas delas.

Pensamos a tecnologia também em relação a outras questōes, como a tecnologia nuclear e a própria biotecnologia e os riscos a elas associados. São assuntos extre- 
mamente complexos, que, em países desenvolvidos, ao contrário do nosso, vêm merecendo uma discussão bastante avançada. O problema da tecnologia, do ponto de vista do risco, envolve, também, em muitas situaçōes, uma ampliação da ação do risco. Podemos passar a ter que enfrentar, para o desenvolvimento tecnológico, acidentes catastróficos, por exemplo. Isso acontece no desenvolvimento da indústria química e nuclear, e potencialmente com a própria biotecnologia.

Isto remete a uma discussão extremamente complexa, que passa por quem julga o risco, qual a competência para julgar esse risco, quem vai sofrer com as conseqüências de determinados desenvolvimentos tecnológicos. Por exemplo, o papel e a responsabilidade de determinados indivíduos (técnicos) que não controlam nem entendem o processo como um todo e têm uma participação técnica apenas em parcela do processo. Às vezes, costumo brincar dizendo que não conheço um engenheiro nuclear que ataque a energia nuclear, embora até possa criticar o programa nuclear, como não conheço pessoa da área de biotecnologia que, apesar de possiveis críticas, não defenda o desenvolvimento da biotecnologia em si.

Nesta discussăo, parecem-me extremamente complexas as afirmaçōes que tendem a polarizar os efeitos positivos e negativos do desenvolvimento tecnológico. Penso ser importante trazer o assunto para reflexão especificamente no que se refere à educaçăo. Perder a referência do papel da educação nesse campo é correr o risco de cometer equivocos bastante sérios. Não se pode deixar de pensar a formaçāo do cidadão, e nisso está incluída a formação do consumidor e não só e exclusivamente - a qualificação técnico-profissional. Sendo o segundo grau parte integrante do ensino básico, é preciso formular uma proposta de formação que considere o domínio dos fundamentos científicos que subsidiam a execução de algumas técnicas. Nesse sentido, onde se situa a especificidade (ou a necessidade) de determinada qualificação profissional?

Considerando a biotecnologia como um setor de ponta no campo da saúde, como poderia se dar a formação de trabalhadores de nivel médio para essa área? Essa formação exigiria algum tipo de qualificação especifica ou seria suficiente uma formação geral básica, com a ciência e a questão do trabalho perpassando essa formação?

\section{Marília Bernardes}

Năo tenho a menor dúvida de que a formação profissional nessa área exige o domínio de habilitaçōes determinadas e específicas. Isso não conflita, a meu ver, com a necessidade de uma formação geral básica. As duas coisas têm que estar profundamente ligadas e devem trazer a marca da multidisciplinaridade. Não é porque estamos falando em nível médio que não devemos falar no desafio epistemológico, 
na queståo da interdisciplinaridade, da multidisciplinaridade. Não devemos nos restringir ao específico, mas não tenho a menor dúvida de que o específico tem hoje um lugar importantíssimo. Não podemos, também, imaginar que a Fiocruz vá dar conta de todas as disciplinas, de todos os conhecimentos necessários para habilitar alguém no campo das biotecnologias. O processo de trabalho em ciência e tecnoiogia tem um grau de complexidade muito grande, indo da pesquisa básica até a produção industrial, e é preciso definir a composição ideal de conhecimentos, de laboratórios etc., capaz de atender a toda essa complexidade. Existe a questão do controle de qualidade, a questão dos ensaios experimentais, os aspectos éticos e de segurança, o problema do meio ambiente, dos impactos, e é lógico que não podemos pretender criar uma escola no campus da Fiocruz que consiga atender a todas as necessidades dessa qualificação. Temos que pensar a nossa inserção de um modo articulado na rede de ensino como um todo, apostando na contribuição de outras instituições.

No caso do ensino da biotecnologia, estamos pensando numa proposta que inclua a discussão econômica, passando pela história da Filosofia da Ciência, e que considere o papel de instituiçôes como a Politécnica da USP, a Escola de Química e o Departamento de Macromoléculas da Universidade Federal do Rio de Janeiro, entre outras. O desafio é discutir a questão do ensino sem deixar de lado o que seja absolutamente relevante do ponto de vista técnico, para não cair no teorismo. Aliás, penso que esse momento já foi vivido e ultrapassado pela Escola Nacional de Saúde Pública. Por conta de um pragmatismo excessivo, de certo modo nos afastamos dos valores acadêmicos. Não se trata de discutir ciência e tecnologia porque é moderno e está na moda. É uma questão de sobrevivência para as instituições e, dentro da Fiocruz, para cada uma de suas unidades. Que conteúdos, que recursos laboratoriais empregar na formaçāo de nossos alunos de nível médio é um assunto que, sendo absolutamente prático, não nega a importância da multidisciplinaridade, que oferece o desafio de trabalhar o conjunto de conhecimentos de diferentes áreas.

Quanto à divisão social do trabalho em saúde, acho cedo para fazer qualquer afirmativa definitiva a respeito. Não sei qual vai ser a tendência, por exemplo, com a informatização do sistema de saúde. Não temos uma indicação empírica precisa para fazer qualquer afirmativa, a não ser especular. Pelo que estamos vivendo hoje, é muito difícil precisar o papel que se atribuirá à introdução da tecnologia em si no momento em que estamos vendo a perspectiva de o próprio Estado ampliar a demanda dos serviços sociais. No nível mais micro, no nível de hospitais, com o desenvolvimento de estudos de avaliação tecnológica, talvez se possa introduzir algum tipo de transformação. Essa expansão dos serviços é uma realidade, e a tecnologia, dentro do projeto de racionalização, tem que ser considerada, pois sua introdução precisa ser racionalizada e deixar de ser caótica. Não se trata simplesmente de discutir a expansão pela expansão, porque ampliar o que existe não serve. E aí fica compreendida também a questão dos recursos humanos. 
Sobre a tendência na economia, é preciso ter presente que a Fiocruz não é exclusivamente um setor de serviços, possui também produçāo industrial na saúde, que é certamente a questāo mais desafiadora da instituição. Se a saúde tem um peso relevante no processo de terceirização da economia, também tem essa inserção estratégica, porque, no caso brasileiro, o setor saúde tem um potencial maior que o revelado pela área agrícola para estimular o desenvolvimento brasileiro.

Quanto ao modelo para o desenvolvimento da biotecnologia, defendo o papel da instituição pública, da empresa pública, como estratégico no sentido de alavancar o desenvolvimento, repassando tecnologia ao setor privado, mas também produzindo bens. $O$ modelo brasileiro de desenvolvimento não pode deixar de lado a discussão do papel estratégico da instituição pública. Essa perspectiva considera o que já temos no País, ao contrário da tendência de enfocar apenas o que se está dando no Primeiro Mundo, onde se verifica o seguinte: novas firmas de biotecnologia se desenvolvem a partir do empresário-pesquisador; este, a partir de determinado produto que ele mesmo desenvolve, cria uma empresa que, por sua vez, vira uma pequena firma de biotecnologia, que passa a ter um papel estratégico no nível das grandes corporações. Parece-me que o caminho brasileiro não será esse, porque nossa capacitação está nas instituições públicas, na Fundação Oswaldo Cruz, por exemplo, nas universidades. Diante de tal situação, penso que o projeto de desenvolvimento dessas instituiçôes deve ter prioridade absoluta.

\section{Rogério Valle}

Dentre tantas indagaçōes, acabamos selecionando o que nos é mais significativo. Para mim, o mais pertinente seria enfatizar que perguntar pelos 'impactos sociais' de uma técnica é abordar um falso tema. Essa questão dos 'impactos', além de ser um anglicismo mal traduzido, dá a idéia de que se trata de duas bolas de bilhar, completamente autônomas, que se vão chocar. Vários exercícios de física passam por aí. Não se trata de discutir qual o impacto da técnica sobre a sociedade, pois essa é exatamente uma visão do determinismo técnico da sociedade, onde as duas coisas sāo completamente separadas. Nesse sentido, também não me refiro, de modo algum, à expressão "revolução científico-tecnológica", muito difundida entre os economistas.

Pode-se exemplificar com o computador. Em que o uso do computador pode atrapalhar a vida de um médico na sua análise clínica? Certamente, complica alguma coisa, mas será que seu efeito é eliminar a figura do médico? Há pouco tempo, trabalhava com um programa de estatística e inseri quatrocentas observaçōes de um fenômeno. O programa fornecia automaticamente vinte estatísticas possíveis. $\mathrm{O}$ que fazer com as vinte respostas? Devo tentar entender, interpretar. Entāo, das vinte, descarto dez, porque correspondem a métodos baseados em distribuição nor- 
mal, e não vejo nenhuma razão para aceitar a hipótese. Das dez restantes, escolho as que podem e as que nảo podem ser aplicadas. Vou, afinal, me fixar em duas ou três, que são diferentes, mas se aplicam melhor ao caso. Em última análise, o computador fornece uma série de dados, mas deixa em aberto a interpretação. Penso que a situação do operário que trabalha numa linha de fabricação é semelhante à do médico, pois em ambas o computador é um instrumento que processa dados e resultados que necessitam ser interpretados.

O verdadeiro desafio para o médico, para o operário, para o engenheiro é compreender, transformar a visão que possuem da profissão. O médico deve entender que náo pode dizer o que é a doença. Na verdade, ele apenas interpreta os dados que aparecem na máquina. A transformação mais radical estaria na compreensão de seu próprio trabalho, na representação que tem de si mesmo. Entender, finalmente, que não lidamos com coisas, mas com interpretações delas. É essa a transformação mais difícil, que está no nível das mentalidades, das representações e que, necessariamente, requer um esforço de elucidação. É nesse campo que o sistema de educação tem papel fundamental. 



\section{Homenagem \\ A Joaquim Alberto Cardoso de Melo ${ }^{1}$}

Feitos farão tão dignos de memória

Que não caibam em verso ou larga história

Os Lusiadas

Quincas, meu irmãozinho:

Não ria, você já sabia que eu ia começar com Camōes. É sempre assim, e você merece.

Criaram um prêmio com seu nome, e hoje, dia da entrega, me encarregaram da homenagem.

Por que eu? Por sua causa. Porque nós éramos amigos. Por causa da nossa correspondência, que você publicou em lívro. Bem, estou dizendo coisas que você já sabe.

Sei que hoje você está acima dessas coisas. Mas tenha paciência, não se irrite, nem dê murros na mesa. Nós ainda estamos do lado de cá, e, você sabe, aqui é assim.

O livro foi um sucesso. ${ }^{2}$

Não? Ora, você já sabe que sim.

Certamente, foram os meus componentes narcíseos que me levaram, num primeiro movimento, ao texto que escrevi para o seu livro. Reli e gostei, transcrevo algumas passagens.

1 Discurso proferido em 11/03/94, em Manguinhos, por ocasião da entrega do prêmio Joaquim Cardoso de Melo a Luís Castiel.

2 O autor refere-se ao livro Educação: razão e paixão, organizado por J. A. C. de Melo, publicado pela Ensp/Fiocruz, em 1993 (Nota dos Orgs.). 
Sim, quero the informar, ainda, que escrevo com caneta de pena, de molhar no tinteiro, daquelas com que nós aprendemos a escrever no colégio. E ainda passei a limpo.

"Foi certamente a sua amizade por mim que fez com que fosse eu o escolhido para a apresentaçăo desta coletânea. Também por amizade aceitei. Na primeira passada de olhos, tentando ordenar o material, fiquei encantado em ler uma citação que Sherrine Maria faz de uma passagem de Lewis Carrol:

Não se pode acreditar em coisas impossiveis, diz Alice.

Suponho que tens falta de treino, diz a Rainha (...)

Aconteceu-me, algumas vezes, acreditar em seis coisas impossiveis, antes do pequeno almoço.

Penso que nada seria mais adequado a um livro sobre educação, especialmente um livro nascido na Escola Nacional de Saúde Pública.

Edmar Terra Blois, o fundador desta casa (hoje, estátua no nosso hall de entrada), costumava dizer: 'Vamos criar uma escola, com fantasia e audácia.' E completava: 'Essa escola será tanto mais competente, quanto mais se aproximar da Universidade da Lapa.'

Ele se referia aos encontros no final da noite, entre cientistas, poetas, filósofos, vagabundos e, naturalmente, prostitutas, nos bares do bairro boêmio.

E Sávio Antunes - estamos devendo a ele a homenagem mais do que merecida e que ainda não veio -, companheiro de Blois, também grande figura desta casa e que tão profundamente marcou a nossa maneira de pensar, acrescentava: 'Lá, os debates eram muito mais estimulantes do que nas salas de aula da Faculdade.'

Era a nossa escola no seu início, nos seus tempos heróicos, cujo espírito você soube tão bem captar e desenvolver. Livre, como deve ser todo centro de ensino, um pouco anárquica, como também deve ser, e com muita audácia. Apostando no futuro."

Foi audácia, naqueles tempos, a criação do Departamento de Ciências Sociais. Não a partir da organização das bases, através de lutas e sacrifícios, como já ouvi ser afirmado pelos corredores, mas pela vontade soberana de um déspota esclarecido. Lamento, mas, meninos, eu vi.

Como você se lembra, Quincas, estávamos ambos em excelente estado de espírito naquela época.

Passo os olhos por outra passagem: 
"Faz frio aqui em Petrópolis. Depois do jantar e de uma costumeira caminhada pelos jardins de Turris Eburnea com Branca Maria e nosso cão, fui para o escritório para uma leitura mais atenta dos textos."

O cão, nosso querido Leão, morreu, como você talvez saiba. Foi um dos seres mais inteligentes e afetuosos (razăo e paixăo) que conheci em toda a minha vida. Procure por ele aí, tenho certeza de que se tornaráo bons amigos.

E ainda, outra passagem:

"São onze horas da noite. A essa hora, inexoravelmente, a governanta me traz o chá. Branca Maria, encantadora como sempre, vai ler, para mim, trechos da tese que está escrevendo, $\mathrm{O}$ ensino nos tempos de Oswaldo, com toda a força da evocação, que ela sabe tão bem fazer, do Rio belle époque."

A tese foi defendida e aprovada com láurea. Você também teve a sua participaçăo. Lembra-se?

Mas o meu egocentrismo năo é absoluto. Passo entăo à sua carta. Afinal de contas, o homenageado é você.

"É que estou tentando ver se essa coletânea pode ser lançada durante a IX Conferência Nacional de Saúde. Por um motivo pessoal. Gostaria de levar meu sobrinho caçula, Luiz Guilherme, para o lançamento, e para conhecer Brasilia. Seria um evento inesquecivel para ambos."

Mais tarde, você me diria que nem isso era fundamental. Penso que, nessa época, você já estava muito mais próximo do Paraíso.

"Esta coletânea foi movida pela amizade, como você pode notar. Esta é uma forma de amor que sempre me fascinou. Desde o ginásio, quando aprendi, no Liceu Pasteur em São Paulo, onde estudei durante nove anos, 'cantigas de amor' e 'cantigas de amigo' (...) Muito importante é a influência dos 'jovens educadores' sobre mim. São meus mestres." [ - sempre esse charme, Quincas - ] "Tenho um grande amor-amizade por eles. Estou também muito entusiasmado com meu curso de filosofia na Escola Politécnica Joaquim Venâncio.

Fico imaginando você e Branca Maria em 'Turris Eburnea', daqui de Mambucaba, enquanto sirvo um chá com uísque e algumas uvas-passas brancas [ - lembra das passas de Esmirna? - I servidas pelo meu mordomo (...).

Receban:, você e Bianca, um abraço afetuoso de seu irmão muito amigo, Joaquim Alberto." 
Meu irmãozinho, como eu aprendi com você naquela época! Até breve, quando poderemos retomar as nossas conversas. De homens livres, sem a mínima preocupação com a platéia, fazendo a crítica da crítica. Livres, como só podem ser aqueles que têm o forte sentimento da morte.

Senhor Presidente da Fiocruz, meu irmãozinho Paulo Buss;

Senhor Diretor da Ensp, meu irmãozinho, muito mais jovem, Adauto José;

Meus senhores e minhas senhoras:

Joaquim Alberto Cardoso de Melo nasceu em Pirajuí, no Estado de São Paulo, a 26 de outubro de 1936. Estudos secundários, ele já nos contou na carta que me escreveu, no Liceu Pasteur. Curso de graduação em Odontologia na USP de 1957 a 1961. Curso de Saúde Pública na Faculdade de Saúde Pública de São Paulo em 1966. Na mesma Faculdade, Curso de Educaçāo em Saúde em 1967. Doutorado na Faculdade de Ciências Médicas da Universidade de Campinas em 1976. Professor da Escola Nacional de Saúde Pública desde 1977, onde, no Departamento de Ciências Sociais - área de Educaçāo -, ministrou cursos e orientou teses de mestrado e doutorado. Foi também, e com grande satisfação sua, professor de Filosofia da Escola Politécnica de Saúde Joaquim Venâncio.

Participou de bancas de exame, de comissões, da organização de seminários e mesas-redondas.

Em 1977, nos legou A Educação e as Práticas de Saúde, sua tese de doutorado.

Com Victor Valla, publicou, em 1987, Sem Educação, ou sem Dinheiro?; com Ramos e Soares, Quem Educa Quem?, em 1989. Em 1990, listava entre seus trabalhos terminados e ainda não publicados Trabalho, Educação e Saúde - da pedagogia a uma sócio-antropologia das investigações de saúde, e já anunciava seu livro Educação: razão e paixão, que sairia póstumo. Ainda em 1990, informava à Coordenaçāo de Pós-Graduação o seu programa de pesquisa: "Consolidação de um quadro teórico-metodológico para a abordagem de trabalho e educação em saúde".

A lista é longa, e o seu prestígio nas questōes de educação é por demais notório. Não cabe aqui análise crítica da obra, nem eu tenho competência para isto.

Por um desses estranhos acasos da vida, leio no discurso de posse de Sérgio Paulo Rouanet, na Academia Brasileira de Letras, uma citação de Lima Barreto: "Para se compreender bem um homem, não se procure saber como oficialmente viveu. É saber como ele morreu." Voltaremos ao tema.

Nossa amizade se aprofundou nos últimos anos de sua vida. Éramos da mesma geração, eu, um mês e três dias mais velho. Tínhamos em comum a memória de nossa época, nossos tempos de juventude. 
Tínhamos lido e nos encantado com os mesmos livros. As histórias de Julio Verne (a inesquecível figura do capitão Nemo, Phileas Fogg e Passepartout, bem mais tarde imortalizados no cinema por David Niven e Cantinflas); as aventuras de Tarzã (que, no nosso tempo, era representado no cinema por John Weissmulier); e, passando da fantasia à realidade, as viagens do capitão Cook e a chegada de Amundsen ao Pólo Sul. E, voltando à fantasia, o eterno Sherlock Holmes; e, ainda, em livro ou no cinema, as histórias da Legião Estrangeira.

E os clássicos, aqueles que estudávamos no colégio, nos cursos de inglês, francês, latim e grego, e os que lemos por nossa conta.

Comentávamos a pedagogia daquele tempo. As histórias pitorescas de alguns professores. E o cinema, onde mesmo na matinê, só se entrava de paletó e gravata. As piadas da época, enfim, o mundo da nossa juventude.

$E$ foi nessas conversas, leves e despretensiosas, muitas vezes com a presença de André, Bianca e Júlio, com quem implicávamos, que fomos ficando cada vez mais amigos.

Encontro ainda, em Rouanet (Mal Estar na Modernidade), uma passagem que teria sido muito bem-vinda se tivesse chegado às nossas mãos naquela época. É a seguinte: "Obelix não respeitava as normas de boas maneiras de Petrônio e, normalmente, os bárbaros brasileiros não circulam de black-tie nas colunas sociais. Comum, aos bárbaros antigos e modernos, é uma ignorância robusta, saudável e, quase diria, metódica. Nossos bárbaros são tão incapazes de citar o título de um romance de Stendhal, como um frígio do tempo de Augusto, de declamar uma ode de Catulo."

Nós já tínhamos passado a fase da crítica, agora fazíamos a crítica dos críticos. Com bom humor, era divertido.

Nos uniu também, nessa época, o projeto educacional para a Escola Politécnica de Saúde.

Homem de paixão, sabia se indignar, se irritava, vociferava, dava socos na mesa.

Durante certa época, de charme, segundo me disse, passou a usar bengala.

Certa vez, no trânsito, um motorista disse algo que o irritou. Não teve dúvidas, respondeu às bengaladas. Uma bengala histórica, que, se me lembro bem, havia pertencido ao seu bisavô.

Mas também tinha savoir faire, ironia, sabia rir tranqüilo das mesquinharias da vida. Apaixonado pela Escola Politécnica, me disse: 'Vou ser professor de filosofia desses meninos. Isso é o que faz sentido para mim nesse momento.' Entrou com um requerimento pedindo transferência da Ensp para o Politécnico. Alguns dias depois, me mostrou a resposta. De início, uma série de elogios à sua pessoa, depois diziam que não podiam abrir mão de um quadro tão competente e, finalmente, que ele poderia, informalmente, dedicar-se em tempo 
integralà Escola Politécnica. Sorrindo, com uma expressão irônica, me disse: 'O que eles querem é a minha vaga'.

Seus cursos de filosofia foram um sucesso. $E$ jamais fez a menor concessão. Jamais fez aquilo que se costuma chamar 'jogar para a platéia'. Hábito nefasto, tâo comum nos dias de hoje e que, em português claro, se chama mentir.

Certa vez, André Malhăo, que era seu assistente, me convidou para debater com os alunos $O$ Nome da Rosa, de Umberto Eco. Amador que sou, preparei perguntas e comentários sobre o período histórico correspondente e alguma coisa sobre a filosofia de Aristóteles. Acostumado a lidar com alunos de pós-graduação, fiquei admirado com a competência dos meninos. Como o Quincas tinha sido competente! E o André também.

Tinha os seus métodos pedagógicos próprios. Alguns alunos tinham o hábito de ouvir suas aulas com a cabeça deitada na carteira, de olhos fechados. À sua reprimenda, responderam que estavam prestando atenção. Na aula seguinte, deitou a cabeça na mesa, fechou os olhos e deu sua aula. Os alunos entenderam: era desagradável.

Mas o seu êxito fica claro nas homenagens que recebeu de diversas turmas. E, especialmente, no carinhoso cordel escrito para ele pelas alunas Tereza Cristina, Ruzia e Rozângela. Não resisto a transcrever algumas passagens:

Filosofar, eis a questão

Com seu cigarro no dedo

Elegante pareceu

Mas depois fumou um giz

E ninguém o entendeu

Pelo seu jeito disciplinado

Uma discussão surgiu

Mas foi o maior barato

Quando na aula ele latiu

Com seu jeito rude

Ele pareceu durão

Mas com seu coração de manteiga

Ele fica um baratão

e ainda:

As terças-feiras sem ele

Jamais seriam as mesmas

A sala, sempre uma rodinha

E ninguém apoiado sobre as mesas.

A vida só existe porque existe a morte. Todos sabernos disso, mas poucos são capazes de incorporar essa idéia ao sentimento. Negar a morte é negar a vida. São a mesma moeda. 
Conheci três pessoas que se comportaram com a mais invejável dignidade diante da morte.

Meu pai, grande clínico e professor, quando alguns dos seus discípulos procuravam atenuar o seu prognóstico, dizia no tom habitual: 'Não seja idiota, você aprendeu comigo, e não foi isso que eu te ensinei.'

Foi sereno, nada de ordens, façam isso ou façam aquilo. Nenhum lamento também. Lembro-me da serenidade que havia em seus olhos, quando me dizia, depois da saída de uma visita que falara, durante horas, sobre temas do momento: 'Isso nāo me interessa mais, prefiro ler as histórias do Pato Donald.'

A mãe da Bianca, dona Mercedes. Mais jovem do que eu. Nem queixas, nem lamentos e, principalmente, nenhum teatro. Lembro-me de um almoço no Praia Bar, poucos dias antes de sua morte. Como as dores fossem fortes, deitou a cabeça sobre a mesa. Quando viu que tínhamos percebido, sorriu suave, ergueu a cabeça e retomou a conversa. Nenhuma explicação, não havia necessidade. Nenhum gesto pretensamente heróico. Simplesmente retomou a conversa. Lembra a morte de Petrônio e Eunice.

A terceira pessoa foi Joaquim Alberto. Conhecedor do diagnóstico, ele como que cresceu, e muito. Ganhou mais segurança no gesto e elegância na postura, e até no trajar.

Acredito que tenha atingido uma dimensão do humano raramente alcançada. Conseguido o encontro consigo mesmo, a sua individualidade, a sua liberdade, a harmonia da paixăo e razăo.

Difícil exprimir isso em palavras.

Nessa época, conversávamos sobre a busca da individualidade, de o homem ser capaz de ouvir o seu coração, de olhar de frente os fantasmas que trazemos dentro de nós. Sem medo. O encontro da liberdade. Só a partir dai, o homem seria capaz de deixar ao mundo a sua mensagem, clara e sem mentir.

Fazíamos a crítica do mundo massificado. Ainda aqui, Rouanet: 'A individualidade submerge cada vez mais no anonimato do conformismo e da sociedade de consumo.' Não se trata tanto de pensar os pensamentos que todos pensam, mas de comprar os videocassetes que todos compram, nos avióes charter em que todos viajam para Miami.

Os sanitaristas apresentam, com júbilo, as taxas que evidenciam o prolongamento da vida. Quanto mais longo esse tempo, mais êxito, mais progresso. Mas nunca estão satisfeitos, sempre querem oferecer ao homem mais e mais tempo sobre a terra.

Lendo certos artigos, penso que há aí embutido um sonho de imortalidade antigo, arcaico. 
Nada de bom nessa imortalidade, a vida só é fascinante porque existe o risco e a morte. Só há vida porque existe a morte.

Passo a palavra ao mestre jorge Luis Borges, o imortal, em O Aleph, publicado em 1949, em tradução livre de Ludovicus Tertius Guanabarinus:

"Em Londres, nos primeiros dias de junho de 1929, o antiquário Joseph Cartaphilus, de Esmirna, ofereceu à princesa de Lucinge os seis volumes em quarto menor (1715-1720) da llíada de Pope. A princesa os adquiriu e, ao recebê-los, trocou com ele algumas palavras. Era, disse-nos ela, um homem envelhecido, terroso, de pele cinzenta e barba cinzenta, com o olhar singularmente vago. Se exprimia, com fluidez e ignorância, em várias línguas; em poucos minutos, passou do francês ao inglês e do inglês a uma enigmática mistura do espanhol de Salonica com o português de Macau. Em outubro, um passageiro de Zeus informou à princesa que Cartaphilus havia morrido ao regressar à Esmirna e que fora enterrado na ilha de los. No último tomo da llíada, foi encontrado o manuscrito que segue."

Leio apenas algumas passagens mais significativas, procurando dar coerência à história:

"Me disse ele que, a partir da outra margem do rio, se situava a Cidade dos Imortais. (...) Năo me lembro se alguma vez acreditei na Cidade dos Imortais, mesmo assim me dediquei com afinco a buscá-la. Flavio, procônsul de Getulia, me cedeu duzentos homens para a tarefa. (...) Partimos de Arsinoe e entramos no tórrido deserto. Atravessamos o país dos trogloditas, que devoram serpentes e não fazem uso das palavras. (...) A todos nós parecia inconcebível que em regiōes tão bárbaras, onde a terra gera tais monstros, pudesse estar situada a cidade. (...)

Depois de longas marchas, vi o que, sem dúvida alguma, era a Cidade dos Imortais. (...) Junto a ela, homens de pele cinzenta, barba emaranhada e inteiramente nus. Sou capaz de reconhecê-los, pertencem à estirpe bestial dos trogloditas, que habitam as margens do mar Arábico e as grutas da Etiópia. Não me espantei que não falassem e que devorassem serpentes (...) como estivesse faminto, sedento e exausto, caí por terra. Os trogloditas não me ajudaram nem a viver, nem a morrer. Foram indiferentes quando lhes pedi que me matassem. (...) Quando, finalmente, consegui me levantar, eu, Marco Flamínio Rufo, tribuno militar de uma das legiōes de Roma, comi a minha primeira ração de carne de serpente. (...) Mas o desejo de ver os imortais, de entrar na maravilhosa cidade, me dava forças para prosseguir. (...) Mas quando consegui chegar, senti medo e repugnância. (...) Um labirinto é construído para confundir os homens, sua arquitetura simétrica tem uma finalidade. Mas, no palácio que eu via, a arquitetura era sem nenhum objetivo. 
Corredores sem saída, janelas inalcançáveis. Uma porta majestosa dava para um poço. (...) Quem ouve com atenção o meu relato há de se lembrar que um homem da tribo me seguiu como um cão até a base da muralha. (...) Essa noite me dispus a ensiná-lo a reconhecer e, quem sabe, a repetir, algumas palavras. (...) A humildade e a miséria do troglodita me trouxeram à memória a imagem de Argos, o velho cão moribundo da Odisséia, e por isso lhe pus o nome de Argos e procurei ensiná-lo. Fracassei e tornei a fracassar. (...) Pensei que Argos e eu pertencêssemos a universos distintos, pensei que nossas percepções eram iguais, mas que Argos as combinava de outra maneira e, com ela, construía outros objetos. Pensei que talvez não existissem objetos para ele, mas um rápido e contínuo jogo de impressões brevíssimas. Pensei em um mundo sem memória e sem tempo. (...) Muitos anos se passaram, até que certa manhă choveu torrencialmente. (...) Corri nu para a chuva. (...) Argos gemia.. (...) Argos, então eu the gritei, Argos! (...) Foi quando, como se descobrisse algo perdido e esquecido há muito tempo, ele balbuciou: 'Argos, o cão de Ulisses'. Eu the perguntei, então: 'O que você sabe da Odisséia?' A prática do grego lhe era penosa.Tive que repetir a pergunta. 'Muito pouco', disse. 'Menos que o rapsodo mais vulgar. Já se passaram mil e cem anos, desde que eu a inventei'. Então, tudo se tornou claro para mim: os trogloditas eram os imortais."

Mas o tempo já vai longe, e para nós, mortais, do lado de cá, ele é fundamental.

É tempo de terminar, e termino com uma passagem do Quincas com Roland ${ }^{3}$ em artigo de abertura do livro: ${ }^{4}$

"Poder resgatar aquilo que move, comove, emociona. Não seria esse um caminho possível para o reencantamento do universo, um reencontro com a vida, mesmo que seja para a morte?"

Luiz Fernando Ferreira

Professor Titular da Ensp/Fiocruz

3 Referência a Fermin Roland Schramn, pesquisador da Ensp/Fiocruz (Nota dos Orgs).

4 Trata-se do mesmo livro a que se referiu no início deste texto: Educaçāo: razão e paixăo (Nota dos Orgs). 


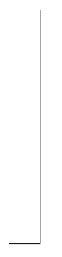




\section{OUTROS TÍTULOS DA EDITORA FIOCRUZ EM CATÁLOGO*}

- Estado sem Cidadãos: seguridade social na América Latina. Sônia Fleury, 1994. 249p.

- Saúde e Povos Indigenas. Ricardo Santos \& Carlos E. A. Coimbra (Orgs.), 1994. 251p.

- Saúde e Doença: um olhar antropológico. Paulo César Alves \& Maria Cecília de Souza Minayo (Orgs.), 1994. 174p.

- Principais Mosquitos de Importância Sanitária no Brasil. Rotraut A. G. B. Consoli \& Ricardo Lourenço de Oliveira, 1994. 174p.

- Filosofia, História e Sociologia das Ciências I: abordagens contemporâneas. Vera Portocarrero (Org.), 1994. 268p.

- Psiquiatria Social e Reforma Psiquiátrica. Paulo Amarante (Org.), 1994. 202p.

- O Controle da Esquistossomose. Segundo relatório do Comitê de Especialistas da OMS, 1994. 110p.

- Vigilância Alimentar e Nutricional: limitaçōes e interfaces com a rede de saúde. Inês Rugani R. de Castro, 1995. 108p.

- Hanseníase: representações sobre a doença. Lenita B. Lorena Claro, 1995. 110p.

- Oswaldo Cruz: a construção de um mito na ciência brasileira. Nara Britto, 1995. 111p.

- A Responsabilidade pela Saúde: aspectos jurídicos: Hélio Pereira Dias, 1995. 68p.

- Sistemas de Saúde: continuidades e mudanças. Paulo M. Buss \& Maria Eliana Labra (Orgs.), 1995. 259p.

- Só Rindo da Saúde. Catálogo de exposição itinerante de mesmo nome, 1995. 52p.

- A Democracia Inconclusa: um estudo da Reforma Sanitária brasileira. Silvia Gerschman, 1995. 203p.

- Atlas Geografico de las Malformaciones Congénitas en Sudamérica. Maria da Graça Dutra (Org.), 1995. 144p.

- Ciência e Saúde na Terra dos Bandeirantes: a trajetória do Instituto Pasteur de São Paulo no período 1903-1916. Luiz Antonio Teixeira, 1995. 187p.

- Profissões de Saúde: uma abordagem sociológica. Maria Helena Machado (Org.), 1995. 193p.

- Recursos Humanos em Saúde no Mercosul. Organização Pan-Americana da Saúde, 1995. 155p.

*por ordem de lançamento/ano. 
- Tópicos em Malacologia Médica. Frederico Simões Barbosa (Org.), 1995. 314p.

- Agir Comunicativo e Planejamento Social: uma crítica ao enfoque estratégico. Francisco Javier Uribe Rivera, 1995. 213p.

- Metamorfoses do Corpo: uma pedagogia freudiana. Sherrine Njaine Borges, 1995. 197p.

- Política de Saúde: o público e o privado. Catalina Eibenschutz (Org.), 1996. 364p.

- Formação de Pessoal de Nível Médio para a Saúde: desafios e perspectivas. Escola Politécnica de Saúde Joaquim Venâncio (Org.), 1996. 222p.

- Tributo a Vênus: a luta contra a sífilis no Brasil, da passagem do século aos anos 40. Sérgio Carrara, 1996. 339p.

- O Homem e a Serpente: outras histórias para a loucura e a psiquiatria. Paulo Amarante, 1996. 141p.

- Raça, Ciência e Sociedade. Ricardo Ventura Santos \& Marcos Chor Majo (Orgs.), 1996. 252p. (Co-ediçăo com o Centro Cultural Banco do Brasil)

- Biossegurança: uma abordagem multidisciplinar. Pedro Teixeira \& Silvio Valle (Orgs.), 1996. 364p.

- VI Conferência Mundial sobre a Mulher. Série Conferências Mundiais das Naçỏes Unidas, 1996. 352p. (Co-ediçāo com o Conselho Nacional dos Direitos da Mulher).

- Prevención Primaria de los Defectos Congénitos. Eduardo E. Castilla, Jorge S. Lopez-Camelo, Joaquin E. Paz \& lêda M. Orioli, 1996. 147p.

- Clínica e Terapêutica da Doença de Chagas: uma abordagem prática para o clínico geral. João Carlos Pinto Dias \& José Rodrigues Coura (Orgs.), 1997. 486p.

- Do Contágio à Transmissão: ciência e cultura na gênese do conhecimento epidemiológico. Dina Czeresnia, 1997. 120p.

- A Endemia Hansênica: uma perspequitiva multidisciplinar. Marcos de Souza Queiroz \& Maria Angélica Puntel, 1997. 120p.

- Avaliação em Saúde: dos modelos conceituais à prática na análise da implantação de programas. Zulmira Maria Araújo Hartz (Org.), 1997. 120p.

- Fome: uma re(leitura de Josué de Castro). Rosana Magalhães, 1997, 87p.

- A Miragem da Pós-Modernidade: democracia e políticas sociais no contexto da globalização. Silvia Gerschman \& Maria Lúcia Werneck Vianna (Orgs.), 1997. 226p.

- Eqüidade e Saúde: contribuições da Epidemiologia. Rita Barradas Barata, Maurício Lima Barreto, Naomar de Almeida Filho e Renato P. Veras (Orgs). Série Epidemiológica, vol I. 260p. (Co-edição com a Abrasco.

- Diários de Langsdorff - Voll (Rio de Janeiro e Minas Gerais, 08 de maio de 1824 a 17 de fevereiro de 1825), 400p e Vol. II (São Paulo, de 26 de agosto de 1825 a 22 de novembro de 1826). Danúzio Gil Bernadino da Silva (Org.), 1977. 333p. (Co-edição com Assoc. Intern. Estudos Langsdorff e Casa de Oswaldo Cruz)

- Os Médicos no Brasil: um retrato da realidade. Maria Helena Machado (Coord.), 1997. 246p. 

R. Hilár1o Ribelro, 154 - Pça. da Bandeira

Rio de Janeiro - RJ

Tel.: (O21) 569-0594 - Fax: (O21) 204-0684 